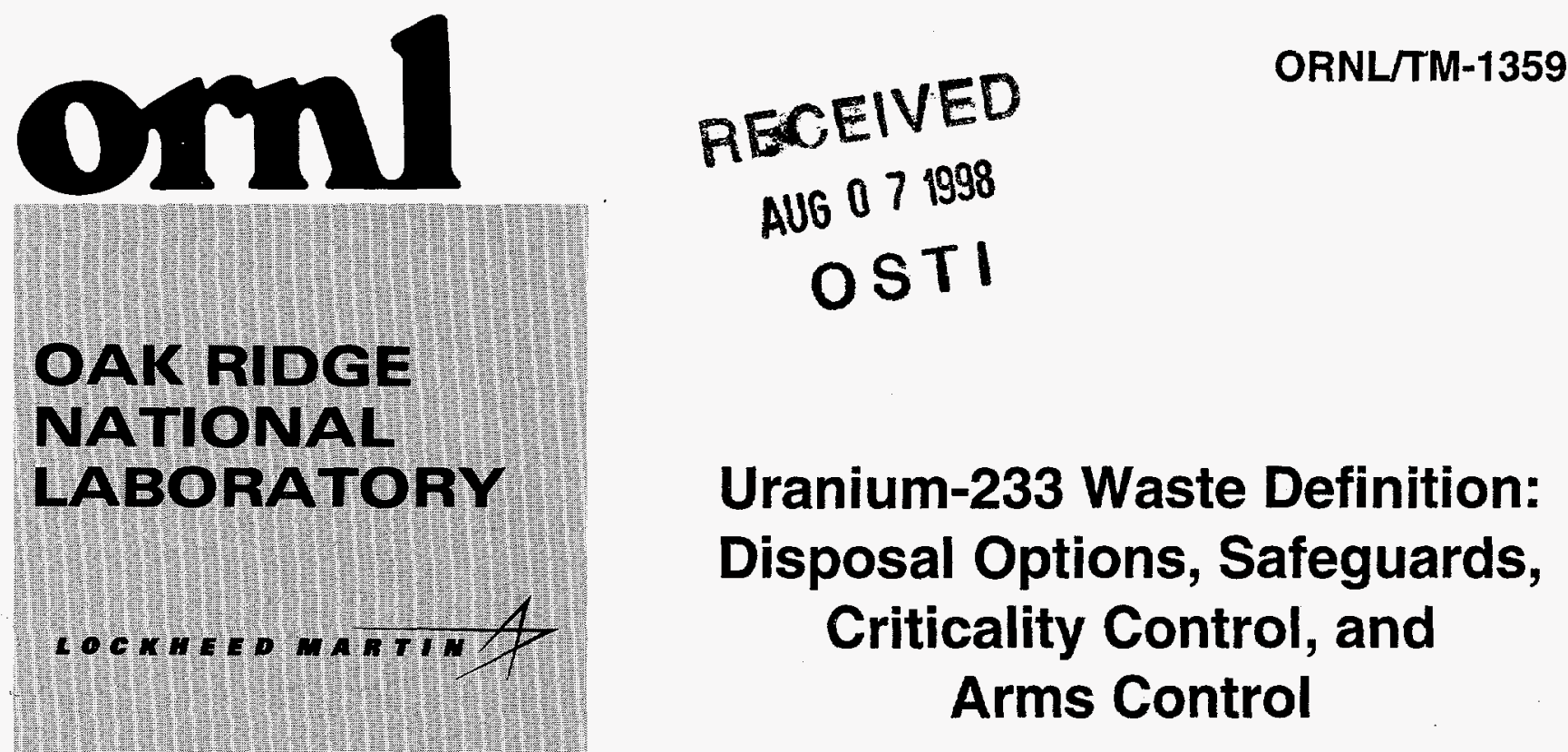

C. W. Forsberg

S. N. Storch

L. C. Lewis

MAMAGED AND OPEERATEO BY

LOCKHEED WARTIN ENERGY RESEARCH CORPORATION FOR THE UNTED STATES

DEPARTUENT OF ENEROY 
This report has been reproduced directly from the best available copy.

Available to DOE and DOE contractors from the Office of Scientific and Technical Information, P.O. Box 62, Oak Ridge, TN 37831; prices available from (615) 576-8401. FTS 626-8401.

Available to the public from the National Technical Information Service, U.S. Department of Commerce, 5285 Port Royal Rd., Springfield, VA 22161.

This report was prepared as an account of work sponsored by an agency of the United States Government. Neither the United States Government nor any agency thereof, nor any of their employees, makes any warranty, express or implied, or assumes any legal liability or responsibility for the accuracy, completeness, or usefulness of any information, apparatus, product, or process disclosed, or represents that its use would not infringe privately owned rights. Reference herein to any specific commercial product, process, or service by trade name, trademark, manufacturer, or otherwise, does not necessarily constitute or imply its endorsement, recommendation, or favoring by the United States Govermment or any agency thereot. The views and opinions of authors expressed herein do not necessarily state or reflect those of the United States Government or any agency thereof. 


\section{DISCLAIMER}

This report was prepared as an account of work sponsored by an agency of the United States Government. Neither the United States Government nor any agency thereof, nor any of their employees, makes any wartanty, express or implied, or assumes any legal liability or responsibility for the accuracy, completeness, or usefulness of any information, apparatus, product, or process disclosed, or represents that its use would not infringe privately owned rights. Reference herein to any specific commercial product, process, or service by trade name, trademark, manufacturer, or otherwise does not necessarily constitute or imply its endorsement, recommendation, or favoring by the United States Government or any agency thereof. The views and opinions of authors expressed herein do not necessarily state or reflect those of the United States Government or any agency thereof. 


\section{DISCLAIMER}

Portions of this document may be illegible in electronic image products. Images are produced from the best available original document. 


\title{
Uranium-233 Waste Definition: Disposal Options, Safeguards, Criticality Control, and Arms Control
}

\author{
C. W. Forsberg and S. N. Storch \\ Oak Ridge National Laboratory ${ }^{*}$ \\ Oak Ridge, Tennessee 37831-6180 \\ Tel: (423) 574-6783 \\ Fax: (423) 574-9512 \\ E-mail: forsbergcw@ornl.gov \\ L. C. Lewis \\ Idaho National Engineering and Environmental Laboratory \\ Idaho Falls, Idaho 83415 \\ Tel: (208) 526-3795 \\ Fax: (208) 526-4902 \\ E-mail: llewis@inel.gov
}

July 7,1998

*Managed by Lockheed Martin Energy Research Corp. under contract DE-AC05-96OR22464 for the U.S. Department of Energy. 



\section{CONTENTS}

LIST OF FIGURES $\ldots \ldots \ldots \ldots \ldots \ldots \ldots \ldots \ldots \ldots \ldots \ldots \ldots \ldots \ldots \ldots \ldots \ldots \ldots \ldots \ldots$

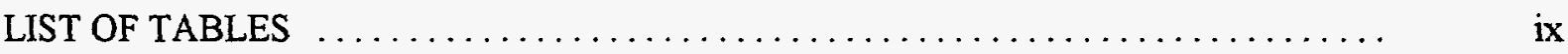

ACRONYMS AND ABBREVIATIONS $\ldots \ldots \ldots \ldots \ldots \ldots \ldots \ldots \ldots \ldots \ldots \ldots \ldots \ldots \ldots \ldots$

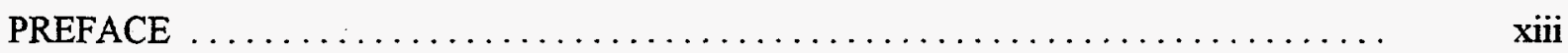

EXECUTIVE SUMMARY $\ldots \ldots \ldots \ldots \ldots \ldots \ldots \ldots \ldots \ldots \ldots \ldots \ldots \ldots \ldots \ldots \ldots \ldots$

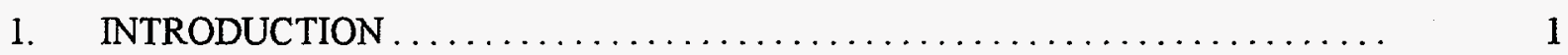

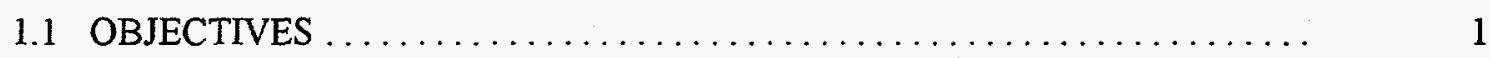

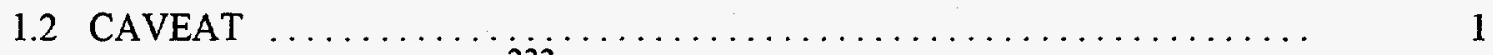

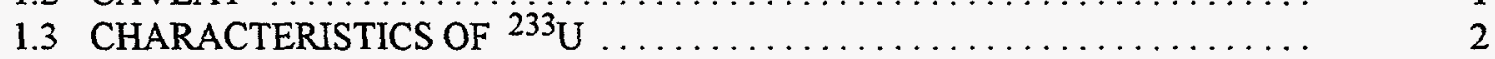

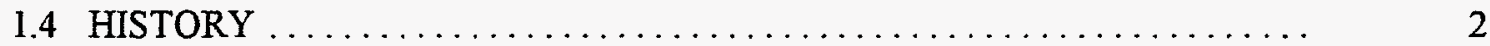

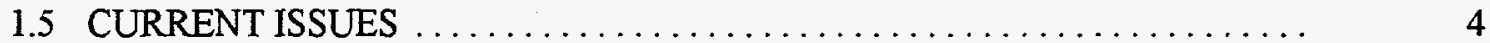

1.6 CATEGORIZATION OF ${ }^{233}$ U CONTAINING MATERIALS $\ldots \ldots \ldots \ldots \ldots \ldots$

1.7 REPORT ORGANIZATION $\ldots \ldots \ldots \ldots \ldots \ldots \ldots \ldots \ldots \ldots \ldots \ldots \ldots \ldots \ldots \ldots$

2. INVENTORY OF ${ }^{233}$ U-BEARING MATERIALS $\ldots \ldots \ldots \ldots \ldots \ldots \ldots \ldots \ldots$

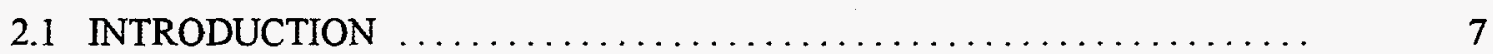

2.2 CONCENTRATED FISSILE MATERIAL (NONWASTE) INVENTORY $\ldots \ldots$.

2.3 EXCEPTION-CASE MATERIAL INVENTORY $\ldots \ldots \ldots \ldots \ldots \ldots \ldots \ldots$

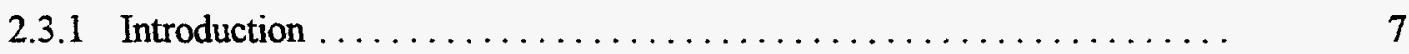

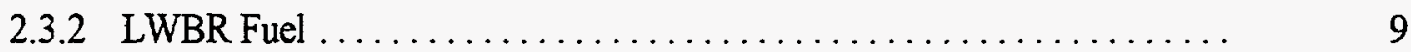

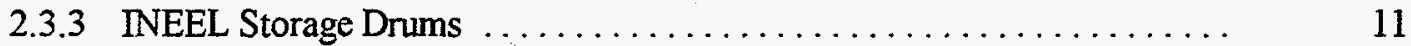

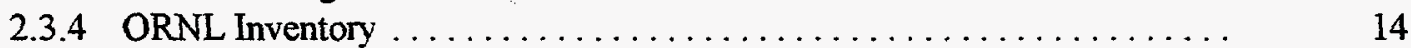

2.3 .5 Hanford Inventory . . . . . . . . . . . . . . . . . . . . . . . . .

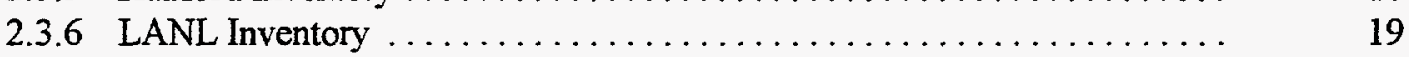

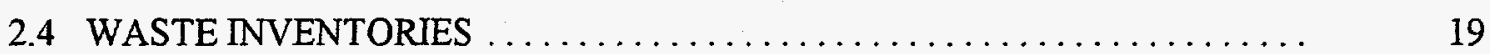

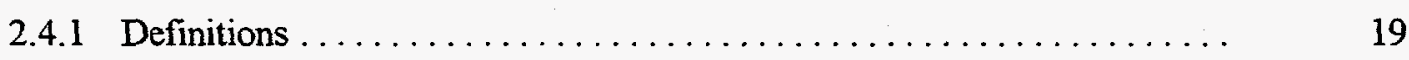

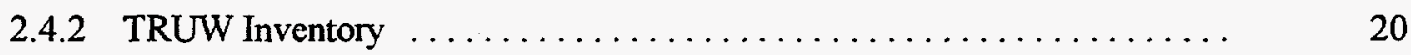

2.4.3 Inventory Summary in Waste Drums and Containers ........... 20

3. DISPOSAL AND DISPOSITION OPTIONS $\ldots \ldots \ldots \ldots \ldots \ldots \ldots \ldots \ldots \ldots \ldots \ldots \ldots$

3.1 PATHWAYS FOR DISPOSAL AS A WASTE OR DISPOSITION AS A

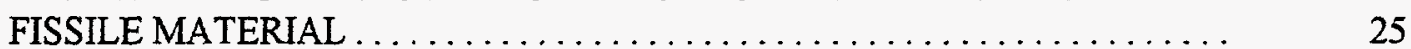

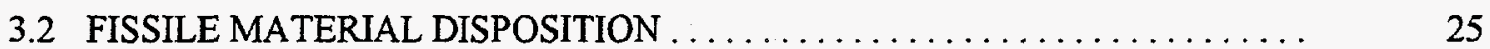




\section{CONTENTS (continued)}

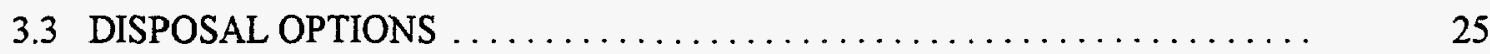

3.3.1 Requirements for Disposal . . . . . . . . . . . . . . . . . . . . .

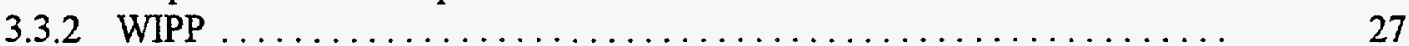

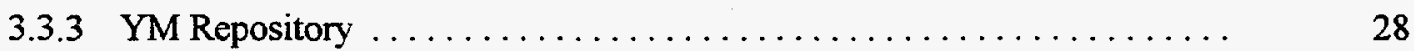

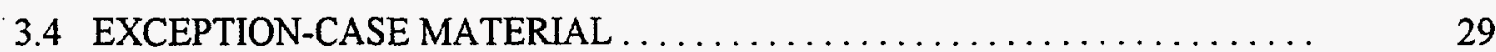

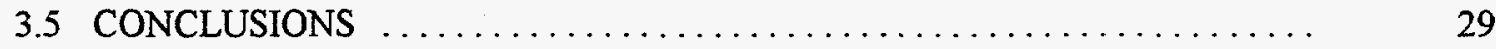

4. NUCLEAR CRITICALITY ISSUES IN DISPOSAL $\ldots \ldots \ldots \ldots \ldots \ldots \ldots \ldots \ldots \ldots$

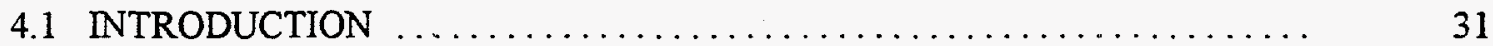

4.2 TECHNICAL AND ENVIRONMENTAL ISSUES $\ldots \ldots \ldots \ldots \ldots \ldots \ldots \ldots$

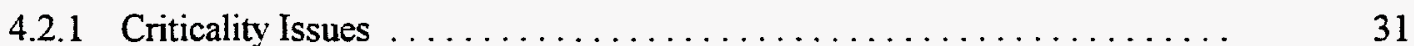

4.2 .2 Uranium Geochemistry . . . . . . . . . . . . . . . . . . . .

4.2.3 Fate of Fissile Uranium in a Disposal Site . . . . . . . . . . . . . .

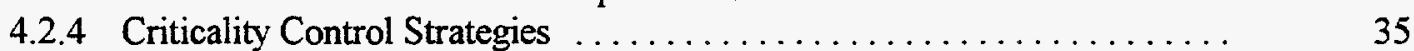

4.2 .5 Allowable ${ }^{233} \mathrm{U}$ Concentrations in Wastes . . . . . . . . . . . . . . 36

4.2.6 Whole-Repository Issues . . . . . . . . . . . . . . . . .

4.2.7 Implementation of a Criticality Control Strategy Based on DU . . . . . $\quad 40$

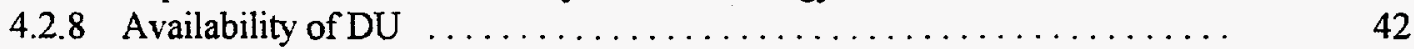

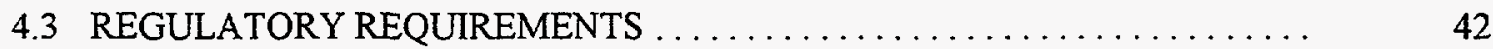

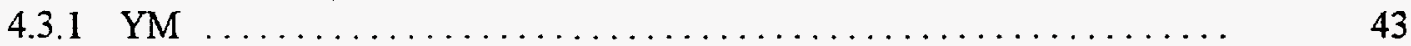

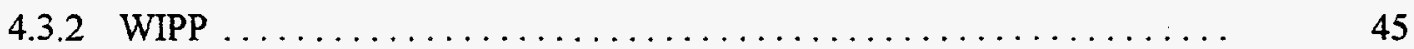

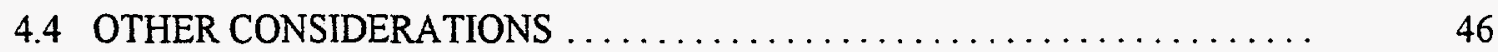

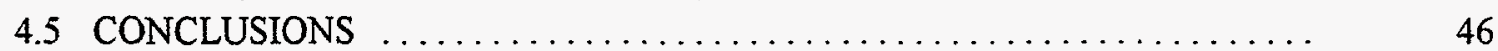

4.5.1 Categorization of ${ }^{233}$ U-Containing Materials ............... 46

4.5.2 Existing Waste Not Requiring Further Processing or Packaging for Other

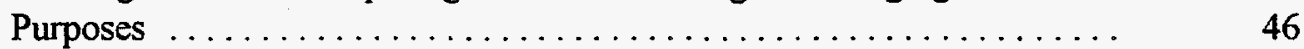

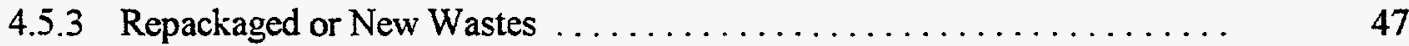

5. ARMS CONTROL, SAFEGUARDS, AND WASTE MANAGEMENT $\ldots \ldots \ldots \ldots .49$

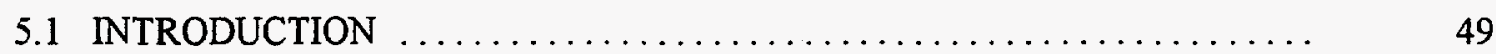

5.2 STRUCTURE OF THE DIVIDING LINE BETWEEN WEAPONS-USABLE ${ }^{233} \mathrm{U}$ AND WASTES $\ldots \ldots \ldots \ldots \ldots \ldots \ldots \ldots \ldots \ldots \ldots \ldots \ldots \ldots \ldots \ldots \ldots$

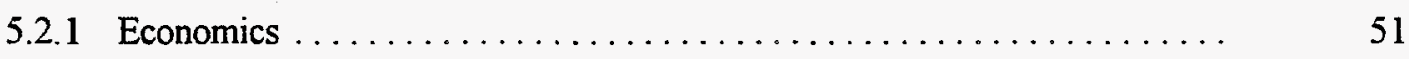




\section{CONTENTS (continued)}

5.2 .2 Domestic Safeguards $\ldots \ldots \ldots \ldots \ldots \ldots \ldots \ldots \ldots \ldots \ldots \ldots \ldots \ldots \ldots \ldots \ldots \ldots$

5.2.2.1 Institutional Structure $\ldots \ldots \ldots \ldots \ldots \ldots \ldots \ldots \ldots \ldots \ldots \ldots$

5.2.2.2 DOE Domestic Safeguards and Wastes ............... 53

5.2.2.3 DOE Domestic Safeguards as Applied to ${ }^{233} \mathrm{U}$ Wastes ....... 55

5.2 .3 International Safeguards $\ldots \ldots \ldots \ldots \ldots \ldots \ldots \ldots \ldots \ldots \ldots \ldots \ldots$

5.2.4 Arms Control and the Spent Fuel Standard ................. 60

5.3 ISSUES ASSOCIATED WITH DOMESTIC SAFEGUARDS $\ldots \ldots \ldots \ldots \ldots$

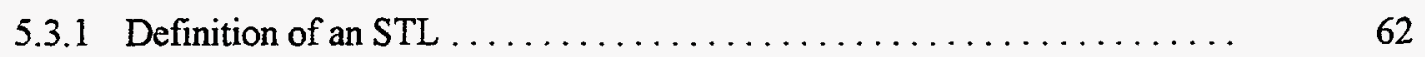

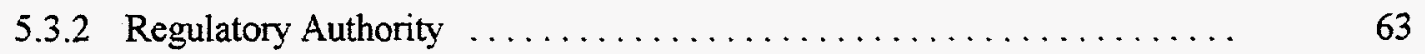

5.3.3 Effectiveness of DOE STLs to Protect Against Domestic Threats ....... 63

5.3.4 Concerns About Concentrated Fissile Materials Inside Larger WPs . . . . . $\quad 64$

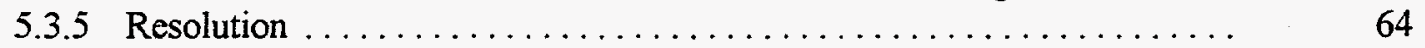

5.4 ISSUES ASSOCIATED WITH THE SPENT FUEL STANDARD . . . . . . . . 67

5.5 SAFEGUARDS AND ARMS-CONTROL ${ }^{233}$ U FISSILE

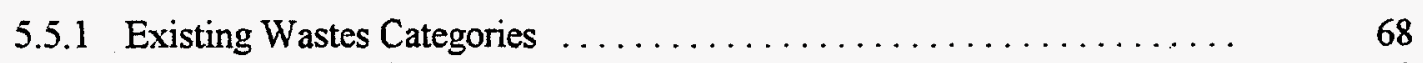

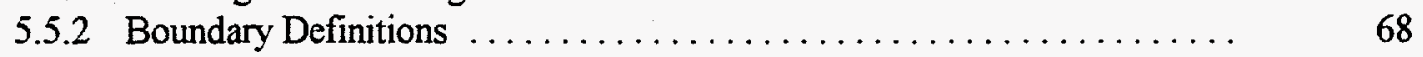

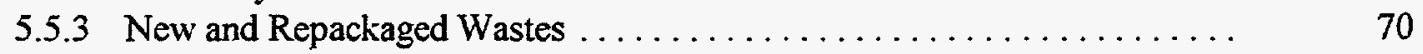

6. CONCLUSIONS $\ldots \ldots \ldots \ldots \ldots \ldots \ldots \ldots \ldots \ldots \ldots \ldots \ldots \ldots \ldots \ldots \ldots \ldots$

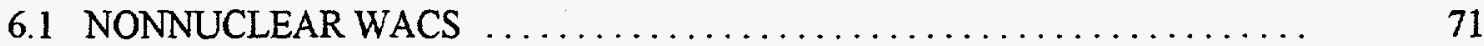

6.2 SAFEGUARDS, NUCLEAR CRITICALITY, AND ARMS CONTROL

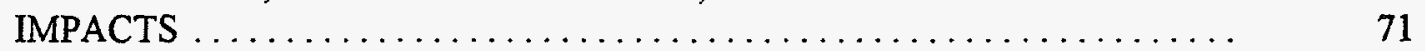

6.3 RECOMMENDATIONS FOR NEW WASTES AND WASTE THAT IS

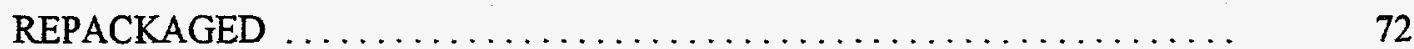

6.4 WASTE AND FISSILE INVENTORIES BASED ON THE ABOVE $\ldots \ldots \ldots$

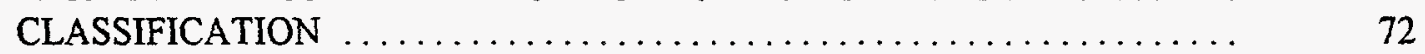

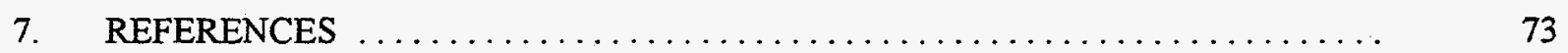

Appendix A: DETAILED CHARACTERISTICS OF SITE ${ }^{233} \mathrm{U}-\mathrm{BEARING}$

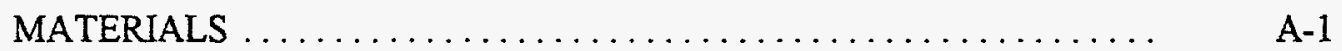

Appendix B: $\quad$ EQUTVALENCE OF ${ }^{233} \mathrm{UAND}^{235} \mathrm{U} \ldots \ldots \ldots \ldots \ldots \ldots \ldots \ldots \ldots \ldots \ldots$ 



\section{LIST OF FIGURES}

Fig. ES. $1 \quad$ Definition of ${ }^{233} \mathrm{U}$-containing materials $\ldots \ldots \ldots \ldots \ldots \ldots \ldots \ldots \ldots \ldots \ldots \ldots \ldots$

Fig. 2.1 Section views of the dry-vault design for both unirradiated (exception-case material) and irradiated LWBR fuel storage dry vaults at INEEL . . . . . . . . . . .

Fig. 2.2 Axial and radial views of storage canisters for unirradiated LWBR fuel (exceptioncase material)

Fig. 2.3 Six drums of ${ }^{233} \mathrm{U}$ waste stored inside a lead-lined overpack

Fig. 2.4a Typical DOT Specification $6 \mathrm{M}$ : a $6 \mathrm{M}$ overpack containing a $2 \mathrm{R}$ container ......

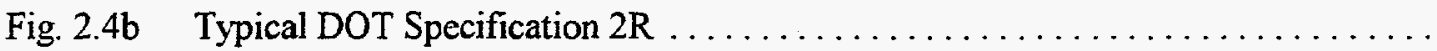

Fig. 2.5 Quantities of ${ }^{233} \mathrm{U}$ in 55 -gal (208-L) waste drums and containers $\ldots \ldots \ldots \ldots .24$

Fig. 3.1 Technical options for management of ${ }^{233}$ U-containing materials $\ldots \ldots \ldots \ldots \ldots 26$

Fig. 4.1 Natural and man-made formation of uranium ore deposits. . . . . . . . 33

Fig. 4.2 Natural uranium enrichment levels occurring over geological time. . . . . . . . 37

Fig. 4.3 Decay pathways, half-lives, and SCMLs of fissionable isotopes .......... 41

Fig. $4.4 \quad$ Advisory and regulatory structure for the YM project. $\ldots \ldots \ldots \ldots \ldots \ldots \ldots$

Fig. $5.1 \quad$ Noneconomic factors impacting the definition of waste $\ldots \ldots \ldots \ldots \ldots \ldots \ldots$

Fig. 5.2 A fissile-containing material is economically considered waste if the cost of fissile material recovery exceeds the cost of producing new fissile materials. .........

Fig. 5.3 The proposed post-cold-war fissile materials cutoff treaty implies weapons states have an interest in fissile-material waste management in foreign countries.

Fig. 5.4 The plutonium or ${ }^{233} \mathrm{U}$ waste form has a potential major impact on safeguards ....

Fig. 5.5 Plutonium and uranium safeguards, SNF, and nuclear criticality limits 



\section{LIST OF TABLES}

Table ES. 1 Inventories of ${ }^{233} \mathrm{U}$ bearing materials $\ldots \ldots \ldots \ldots \ldots \ldots \ldots \ldots \ldots \ldots \ldots \ldots \ldots \ldots$

Table 1.1 Relative characteristics of weapons-usable materials $\ldots \ldots \ldots \ldots \ldots \ldots \ldots$

Table $2.1 \quad$ Inventories of ${ }^{233} \mathrm{U}$-bearing materials $\ldots \ldots \ldots \ldots \ldots \ldots \ldots \ldots \ldots \ldots \ldots \ldots$

Table 2.2 Summary, by major sites, of domestic ${ }^{233} \mathrm{U}$ fissile material (nonwaste) characteristics and inventories $\ldots \ldots \ldots \ldots \ldots \ldots \ldots \ldots \ldots \ldots \ldots \ldots \ldots \ldots \ldots \ldots$

Table 2.3 INEEL exception-case material $\ldots \ldots \ldots \ldots \ldots \ldots \ldots \ldots \ldots \ldots \ldots \ldots \ldots$

Table 2.4 Exception-case material: storage locations and contents of BAPL container shipments of unirradiated LWBR fuel to the INEEL-ICPP . . . . . . . . . 10

Table 2.5 Exception-case material: characteristics of the spare unirradiated LWBR seed module stored in INEEL-ICPP dry storage vault $\mathrm{U}-22 \ldots \ldots \ldots \ldots \ldots \ldots \ldots$

Table 2.6 Total ${ }^{233} \mathrm{U}$ wastes and other exception-case materials at NEEL $\ldots \ldots \ldots \ldots \ldots$

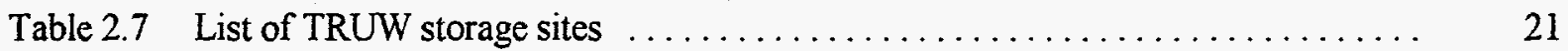

Table 2.8 Current characteristics of DOE site TRUW (mixed and nonmixed) $\ldots \ldots \ldots \ldots .22$

Table 2.9 Isotopic breakdown of uranium mass $(\mathrm{g})$ in DOE site TRUW . . . . . . . . 23

Table 5.1 DOE nuclear material safeguards categories $\ldots \ldots \ldots \ldots \ldots \ldots \ldots \ldots \ldots$

Table 5.2 Attractiveness Level E criteria for SNM allowing for termination of DOE domestic safeguards $\ldots \ldots \ldots \ldots \ldots \ldots \ldots \ldots \ldots \ldots \ldots \ldots \ldots \ldots \ldots \ldots \ldots \ldots \ldots \ldots \ldots \ldots$

Table 5.3 IAEA STLs for plutonium and uranium $\ldots \ldots \ldots \ldots \ldots \ldots \ldots \ldots \ldots \ldots \ldots$

Table 5.4 Proposed categorization of nuclear material including ${ }^{233} \mathrm{U}$ isotopic distinctions .. $\quad 59$ 



\section{ACRONYMS AND ABBREVIATIONS}

ANL Argonne National Laboratory

ANS American Nuclear Society

BAPL Bettis Atomic Power Laboratory

BMU Breeder mock-up

$\mathrm{CM} \quad$ critical mass

CFR Code of Federal Regulations

$\mathrm{CH} \quad$ contact-handled

DOE U.S. Department of Energy

DOE-ID DOE Idaho Operations Office

DOT U.S. Department of Transportation

DU depleted uranium

EIS Environmental Impact Statement

EPA U.S. Environmental Protection Agency

FSAR final safety analysis report

Hanford Hanford Site

HEPA high-efficiency particulate air

HEU high enriched uranium

HLW high-level waste

IAEA International Atomic Energy Agency

ICPP Idaho Chemical Processing Plant (INEEL)

INEEL Idaho National Engineering and Environmental Laboratory

IWMF Interim Waste Management Facility (ORNL)

LANL Los Alamos National Laboratory

LEU low-enriched uranium

LLW low-level waste

LWBR light-water breeder reactor

MTIHM metric tons initial heavy metal

NAS National Academy of Sciences

NRC U.S. Nuclear Regulatory Commission

NWTRB Nuclear Waste Technical Review Board 
OD outer diameter

ORNL Oak Ridge National Laboratory

ppm parts per million

$R \& D \quad$ research and development

RDF Radiochemical Development Facility (ORNL)

$\mathrm{RH} \quad$ remote-handled

ROD Record of Decision

RWMC Radioactive Waste Management Complex (INEEL)

SCML subcritical mass limit

SLD shallow-land disposal

SNF spent nuclear fuel

SNM special nuclear material

STL safeguards termination limits

t metric ton

TRU transuranic

TRUW transuranic waste

U Uranium

WAC waste acceptance criteria

WGP weapons-grade plutonium

WIPP . Waste Isolation Pilot Plant

WP waste package

YM Yucca Mountain

${ }^{232} \mathrm{U} \quad$ Uranium-232

${ }^{233} \mathrm{U} \quad$ Uranium-233

${ }^{235} \mathrm{U} \quad$ Uranium-235

${ }^{238} \mathrm{U} \quad$ Uranium-238 


\section{PREFACE}

This report is one of several reports which map the strategy for the future use and disposition of uranium-233 $\left({ }^{233} \mathrm{U}\right)$ and disposal of wastes containing ${ }^{233} \mathrm{U}$. Other relevant documents from other programs are listed below with a brief description of the contents.

- ORNL/TM-13550-Strategy for the Future Use and Disposition of ${ }^{233} U$ : Overview. This document is a summary of the path forward for disposition of surplus ${ }^{233} \mathrm{U}$. It includes required activities, identifies what major programmatic decisions will be required, and describes the potential disposition options.

- ORNL/TM-13551-Strategy for the Future Use and Disposition of ${ }^{233} U$ : History, Inventories, Storage Facilities, and Potential Uses. This document includes the historical uses, sources, potential uses, and current inventory of ${ }^{233} \mathrm{U}$. The inventory includes the quantities, storage forms, and packaging of the material.

- ORNL/TM-13552 - Strategy for the Future Use and Disposition of ${ }^{233} U$ : Technical Information. This document summarizes scientific information on ${ }^{233} \mathrm{U}$. This includes production methods, decay processes, and the material characteristics. The requirements for storage and disposal are also included.

- ORNL/TM-13553-Strategy for the Future Use and Disposition of ${ }^{233} U$ : Options. This document describes the proposed disposition alternatives, identifies what material in inventory could be treated by each disposition option, and provides an initial analysis of each option. A listing of the legislative or regulatory changes required for each alternative is also provided.

- ORNL/TM-13524-Isotopic Dilution Requirements for ${ }^{233}$ U Criticality Safety in Processing and Disposal Facilities. This document determines and defines how much depleted uranium (DU) must be mixed with ${ }^{233} \mathrm{U}$ to prevent the potential for nuclear criticality under all expected process and disposal facility conditions.

- ORNL/TM-13517-Definition of Weapons Usable ${ }^{233} U$. This document determines and defines how much DU must be mixed with ${ }^{233} U$ to convert the ${ }^{233} U$ into a non-weapons-usable material. 



\section{EXECUTIVE SUMMARY}

\section{OBJECTIVES}

The United States investigated the use of ${ }^{233} \mathrm{U}$ for weapons, reactors, and other purposes from the $1950 \mathrm{~s}$ into the $1970 \mathrm{~s}$. Based on the results of these investigations, it was decided not to use ${ }^{233} \mathrm{U}$ on a large scale. Most of the ${ }^{233} \mathrm{U}$-containing materials were placed in long-term storage. At the end of the cold war, the United States initiated, as part of its arms control policies, a disposition program for excess fissile materials. Other programs were accelerated for disposal of radioactive wastes placed in storage during the cold war. Last, potential safety issues were identified related to the storage of some ${ }^{233} \mathrm{U}$-containing materials. Because of these changes, significant activities associated with ${ }^{233} \mathrm{U}$-containing materials are expected. This report is one of a series of reports (see preface) to provide the technical bases for future decisions on how to manage this material.

A basis for defining when ${ }^{233} \mathrm{U}$-containing materials can be managed as waste and when they must be managed as concentrated fissile materials has been developed. The requirements for storage, transport, and disposal of radioactive wastes are significantly different than those for fissile materials. Because of these differences, it is important to classify material in its appropriate category. The establishment of a definition of what is waste and what is fissile material will provide the guidance for appropriate management of these materials.

Wastes are defined in this report as materials containing sufficiently small masses or low concentrations of fissile materials such that they can be managed as typical radioactive waste. Concentrated fissile materials are defined herein as materials containing sufficient fissile content such as to warrant special handling to address nuclear criticality, safeguards, and arms control concerns. Certain concentrated fissile materials may have no use and are therefore excess material; however, in the context of this report, they are classified and managed by their material characteristics rather than programmatic demand. Thus, even if a concentrated fissile material is not needed, it must not be managed as a waste until it meets waste criteria.

\section{INVENTORY AND CHARACTERISTICS}

The total U.S. inventory of ${ }^{233}$ U-containing materials [excluding that in spent nuclear fuel (SNF)] consists of slightly $<2$ metric tons $(t)$ of uranium containing somewhat $<1$ t of ${ }^{233} U$. Most of the inventory is relatively pure uranium oxides; however, several hundred kilograms are mixed with other materials in several thousand drums, boxes, and special packages. 
Some of these containers are clearly waste. These have small quantities of ${ }^{233} \mathrm{U}$ mixed with broken equipment, process sludges, and other materials. In other situations, the ${ }^{233} U$ is in a relatively concentrated form in small containers packaged in larger shipping containers. The classification of such materials is uncertain. The inventory is primarily at the Oak Ridge National Laboratory and the Idaho National Engineering and Environmental Laboratory.

Uranium-233 has some of the characteristics of plutonium, some of the characteristics of ${ }^{235} \mathrm{U}$, and some unique characteristics. As defined by the International Atomic Energy Agency, a Category I quantity of ${ }^{233} U$ in the context of physical security is $2 \mathrm{~kg}$-the same as that for plutonium-whereas a Category I quantity of ${ }^{235} \mathrm{U}$ is $5 \mathrm{~kg}$. Category I quantities of weapons-usable materials are quantities sufficiently large in terms of building weapons such that there is a need for careful accounting and special security measures. However, like ${ }^{235} \mathrm{U},{ }^{233} \mathrm{U}$ can be isotopically diluted with ${ }^{238} \mathrm{U}$ to convert it to non-weapons-usable material, thus substantially reducing safeguards requirements and arms-control implications. Isotopic dilution of ${ }^{235} U$ to $<20 \mathrm{wt} \%{ }^{235} \mathrm{U}$ in ${ }^{238} \mathrm{U}$ converts ${ }^{235} \mathrm{U}$ into a non-weapons-usable material. Isotopic dilution of ${ }^{233} \mathrm{U}$ to $<12$ wt $\%{ }^{233} \mathrm{U}$ in ${ }^{238} \mathrm{U}$ converts ${ }^{233} \mathrm{U}$ into a non-weapons-usable material. Different isotopic dilutions are required for these two isotopes because of the different nuclear properties of each. Uranium-233 has the chemical characteristics of other uranium isotopes and the accompanying repository nuclear criticality issues associated with uranium geochemistry and migration of uranium in the geological environment.

\section{HISTORY}

Historically a clear economic division has existed between wastes and some concentrated fissile materials. This division (the economic discard limit) was based on economic criteria for materials containing highly-enriched uranium and plutonium. These fissile materials are required to manufacture nuclear weapons and were in short supply during the cold war. Fissile material in any scrap and residue stream was considered waste only if the cost of the recovery of the material exceeded the cost of producing new material. If clean fissile materials could be recovered from the scrap and residue stream for less than the cost of producing new material, the stream was considered concentrated fissile material. The high cold-war economic value of fissile materials resulted in low concentrations of fissile material in the wastes which in turn minimized concerns about nuclear criticality, safeguards, and arms control.

Uranium-235, plutonium, and ${ }^{233} \mathrm{U}$ are the three fissile materials that can be produced in large quantities to manufacture nuclear weapons or to use as a nuclear-reactor fuel. Uranium-233 was investigated for use in nuclear weapons, as a fuel for nuclear reactors, and for other purposes. However, large-scale use was never 
implemented. Because there was no need, an economic criteria to divide ${ }^{233} U$-containing materials into a concentrated fissile-material category and a separate waste category was never developed. Furthermore, much of the institutional structure for management of ${ }^{233} \mathrm{U}$ as a concentrated fissile material or waste was never as fully developed.

\section{CURRENT ISSUES}

Now, with the end of the cold war and with surplus fissile material on hand, the economic criteria used to divide concentrated fissile material from waste no longer exists. The fissile material value of surplus material may be zero or negative. A new basis to categorize concentrated fissile materials and waste has not yet been fully developed for plutonium, ${ }^{235} \mathrm{U}$, or ${ }^{233} \mathrm{U}$. Three issues now affect the definition of wastes and fissile materials.

- Domestic safeguards. Concentrated fissile materials must be safeguarded to prevent their theft by domestic or international terrorists. Existing and proposed waste-management processing, storage, transport, and disposal facilities are not designed as high-security facilities to prevent theft of weapons-usable material. To be a waste, the fissile content must be sufficiently low (enrichment or concentration) such that it is not an attractive target for theft.

- Arms control and international safeguards. The United States has implemented a post-cold-war policy to encourage worldwide reductions in inventories of weapons-usable materials. The objectives include mutually verifiable reductions in weapons-usable fissile materials with Russia and, ultimately, other countries. As part of this policy, the United States has proposed that excess weapons-usable material in the United States and Russia be converted into a form that makes its recovery as difficult or more difficult than recovery of plutonium from light-water reactor SNF. Logically, the criterion, known as the Spent Fuel Standard, should also be applied to all wastecontaining materials; otherwise, any country could adopt waste management policies that declare concentrated fissile materials as waste and bypass the intent of the proposed arms-control treaties to limit weapons-usable fissile material inventories. No policy decisions have yet been made on the applicability of the Spent Fuel Standard to different types of waste. Most fissile-containing wastes generated in the cold war meet the Spent Fuel Standard because they were considered wastes only if fissile material recovery was more difficult than producing new fissile materials. New fissile plutonium and ${ }^{233} \mathrm{U}$ were produced by recovering them from SNF.

- Nuclear criticality in disposal facilities. Regulatory and performance requirements for disposal sites require that nuclear criticality be avoided (1) during the operational phase of the facility and (2) after disposal-site closure. Fissile materials may migrate in a disposal facility over geologic time frames. Waste form composition and special facility design features are required to avoid nuclear criticality. These requirements place limits on the concentrations and quantities of fissile materials in waste.

For ${ }^{233} \mathrm{U}$-containing materials that are defined as wastes, there is the additional complication that no current or planned waste disposal facility can accept ${ }^{233} U$ wastes. The radiological characteristics and hazards of ${ }^{233} \mathrm{U}$-containing wastes are similar to transuranic wastes (TRUW) that contain plutonium. From 
the perspective of public health, safety, and protection of the environment, such wastes could be managed like TRUW. It is planned to dispose of defense TRUW in the Waste Isolation Pilot Plant (WIPP). However, the enabling legislation for the WIPP prohibits the disposal of ${ }^{233} \mathrm{U}$-containing wastes in that facility.

\section{PROPOSED DEFINITION OF WASTE AND CONCENTRATED FISSILE MATERIALS}

Based on analysis, the following definitions are proposed to define ${ }^{233} U$ containing wastes and ${ }^{233} U$ concentrated fissile materials (Fig. ES.1). These definitions are for materials currently in inventory. The definitions should not necessarily be used for future wastes (see recommendation). The specifics of these definitions are within the report.

- Waste. Uranium-233-containing material is waste if it meets three requirements: (1) there is no existing, planned, or proposed use; (2) the ${ }^{233} U$ (a) has a concentration of $<200 \mathrm{~g}^{233} \mathrm{U} / 55$-gal drum or (b) the enrichment level is $<0.66 \mathrm{wt} \%{ }^{233} \mathrm{U}$ in ${ }^{238} \mathrm{U}$; and (3) the ${ }^{233} \mathrm{U}$ (a) has an approximately homogeneous concentration of $<1 \mathrm{~kg}^{233} \mathrm{U} / \mathrm{m}^{3}$ (equivalent to $<200 \mathrm{~g} / 55$-gal drum) or (b) the enrichment level is $<12 \mathrm{wt} \%{ }^{233} \mathrm{U}$ in ${ }^{238} \mathrm{U}$. This definition includes the three requirements (economics, criticality control, and safeguards and arms control) that must be met to allow the material to be handled as other radioactive wastes.

Criticality control is assured (a) by limiting the ${ }^{233} \mathrm{U}$ concentration in the wastes to the same concentration limit as used by WIPP and other waste management facilities for operational safety (DOE April 1996) or (b) by isotopic dilution of ${ }^{233} \mathrm{U}$ with ${ }^{238} \mathrm{U}$ to a ${ }^{233} \mathrm{U}$ isotopic concentration limit that is equivalent to $1 \mathrm{wt} \%{ }^{235} \mathrm{U}$ in ${ }^{238} \mathrm{U}$ (Elam 1997).

Avoidance of special safeguards and arms-control constraints is obtained by (a) limiting the ${ }^{233} \mathrm{U}$ concentration or (b) isotopically diluting the ${ }^{233} \mathrm{U}$ with ${ }^{238} \mathrm{U}$ to make it non-weapons-usable material (Forsberg February 1998). The requirement for an approximately homogeneous concentration of ${ }^{233} \mathrm{U}$ in the wastes explicitly recognizes that a small can of more concentrated ${ }^{233} \mathrm{U}$ in a large waste package (WP) has fundamentally different safeguards and arms control implications than if the ${ }^{233} \mathrm{U}$ is distributed through the waste. If the ${ }^{233} \mathrm{U}$ is concentrated in the waste in a small fraction of the waste, it is easier to recover and this changes the safeguards and security requirements.

Concentrated material is defined herein as containing $>0.15 \mathrm{wt} \%{ }^{233} \mathrm{U}$ in non- ${ }^{238} \mathrm{U}$ materials. This concentration limit is identical to the maximum allowable plutonium content in wastes during the cold war (waste threshold). For containers containing concentrated material, the ${ }^{233} \mathrm{U}$ content of the container is limited to $250 \mathrm{~g} / \mathrm{m}^{3}$ (50 g/drum) with certain other restrictions.

- Exception case. Exception-case material is defined as material that should be examined on a caseby-case basis to determine if it is waste. Many of the post-cold-war arms control and safeguards issues have not been resolved for plutonium and ${ }^{235} \mathrm{U}$. Depending upon what is decided with the management of those materials, decisions can then be made about the specific ${ }^{233} \mathrm{U}$-containing materials. For the purposes herein, exception-case material includes materials not in the definition of wastes as described above and containing up to $12 \mathrm{wt} \%{ }^{233} \mathrm{U}$ (chemical dilution in non- ${ }^{238} \mathrm{U}$ containing materials). 


\section{Concentrated Fissile Material}

\section{Break in Inventory}

\section{$12 w t \% 233 U$ \\ Exception Case Material \\ (Future Management Dependent Upon Pu Precedent and Unique Conditions)}

Waste Defined By Three Requirements

Economic

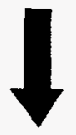

No Value
Criticality

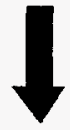

$<200 \mathrm{~g}^{233} \mathrm{U} / 55$-gal drum

or

$<0.66 w t \%{ }^{233} U$ in ${ }^{238} U$
Safeguards

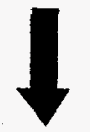

Homogeneous Mixture with

$<1 \mathrm{~kg}^{233} \mathrm{U} / \mathrm{m}^{3}$

(Equivalent to $<200 \mathrm{~g}^{233}$ U/55-gal drum)

or $<12 w t \%{ }^{233} U$ in ${ }^{238} U$

or

More Restrictive

Rules For ${ }^{233} \mathrm{U}$

Concentrated

Wastes

Fig. ES.1. Definition of ${ }^{233} \mathrm{U}$-containing materials. 
The upper limit of exception-case category is close to the maximum concentration of fissile materials proposed for any waste for which safeguards and arms-control restrictions may be reduced. It is also a natural break point in the ${ }^{233} \mathrm{U}$ inventory. There is no significant ${ }^{233} \mathrm{U}$-containing materials between the highest assay ${ }^{233} \mathrm{U}$ fresh fuel $\left(12 \mathrm{wt} \%{ }^{233} \mathrm{UO}_{2}\right.$ in $\left.\mathrm{ThO}_{2}\right)$ and the nearly pure ${ }^{233} \mathrm{U}$ oxides.

- Concentrated fissile material. All other ${ }^{233} U$-containing materials (excluding SNF) are defined as concentrated fissile material. These materials contain $>12 \mathrm{wt} \%{ }^{233} \mathrm{U}$.

This categorization scheme does not necessarily imply that any ${ }^{233} \mathrm{U}$-containing materials will be treated differently than those in the past. What the categorization scheme does is to define wastes and flag some materials as exception-case. Depending upon the results of ongoing policy reviews, the requirements for management of exception-case materials may change significantly and be managed as wastes or as concentrated fissile materials.

\section{PROPOSED RECOMMENDATIONS FOR NEW WASTES AND WASTE THAT IS REPACKAGED}

Some of the ${ }^{233} \mathrm{U}$ waste inventory must be repackaged to meet repository waste acceptance criteria (WACs). Much (perhaps all) of the exception-case material-if considered an economic waste-will have to be repackaged to meet repository WACs. New wastes will be generated by these operations and by future processing of ${ }^{233} U$ fissile materials (1) to be used for medical and other beneficial purposes, (2) to stabilize fissile materials for long-term storage or (3) for fissile material disposition. The evaluations within this report indicate that the following actions-where practicable-should be taken with these future wastes to minimize domestic safeguards, arms control, and criticality issues associated with future wastes:

Where practically feasible, it is recommended that sufficient depleted uranium $(D U)\left({ }^{238} U\right)$ be added to any future WP to isotopically dilute the ${ }^{233} U$ to a concentration level of $<0.66$ wt $\%$ ${ }^{233} U$ in ${ }^{238} U$.

There are several bases for this recommendation:

- Domestic safeguards. Isotopic dilution of ${ }^{233} \mathrm{U}$ to $<12 \mathrm{wt} \%$ with ${ }^{238} \mathrm{U}$ converts weapons-usable ${ }^{233} U$ into non-weapons usable, low-enriched ${ }^{233} U$ (Forsberg February 1998). This conversion minimizes safeguards and security requirements for processing, storage, transport, and disposal.

- Arms control and international safeguards. Isotopic dilution of ${ }^{233} \mathrm{U}$ to $<12 \mathrm{wt} \%$ with ${ }^{238} \mathrm{U}$ meets potential future arms control requirements and meets the spent fuel standard for disposal of fissile materials (Forsberg February 1998).

- Nuclear criticality in disposal facilities. Disposal facilities have the requirement imposed that nuclear criticality be avoided in operations and after site closure. Isotopic dilution of ${ }^{233} \mathrm{U}$ to $0.66 \mathrm{wt} \%{ }^{233} \mathrm{U}$ in ${ }^{238} \mathrm{U}$ minimizes the potential for nuclear criticality (Elam 1997). Isotopic dilution using DU avoids the need to address disposal-site nuclear criticality issues and, in many cases, minimizes waste volume. 
There is no shortage of DU to meet the recommendation. Currently, the U.S. Department of Energy has $\sim 400,000 \mathrm{t}$ of excess DU. It is expected that some type of deep mine or geological disposal is required if the DU is declared a waste. The addition of DU to waste streams is a beneficial use of this material.

\section{WASTE AND FISSILE INVENTORIES BASED ON THE ABOVE CLASSIFICATION}

Table ES. 1 shows the inventory of ${ }^{233} \mathrm{U}$-containing materials based on the previous classification scheme. By volume, most of the ${ }^{233} U$-containing material is waste. An analysis of this inventory indicates that most of the exception case material consists of mixtures of high-temperature fired $\left(>1600^{\circ} \mathrm{C}\right)^{233} \mathrm{U}$ dioxide with thorium dioxide $\left(\mathrm{ThO}_{2}\right)$ from the light-water breeder reactor (LWBR) program. This material has 1 to $12 \mathrm{wt} \%{ }^{233} \mathrm{U}$ when examining small pellets or pellet fractions and significantly lower ${ }^{233} \mathrm{U}$ concentrations when averaged over entire packages. It is in a variety of forms from broken pellets to fresh LWBR fuel assemblies. The material is in (1) drums, (2) boxes, and (3) specially designed pipe components that are respectively located in (a) TRUW retrievable storage berms, (b) TRUW storage buildings, and (c) underground dry storage vaults. Much of the inventory that is in drums is in heavy-wall pipes within the barrels. While there are multiple container types, the basic material is the same.

Table ES.1. Inventories of ${ }^{233}$ U-bearing materials

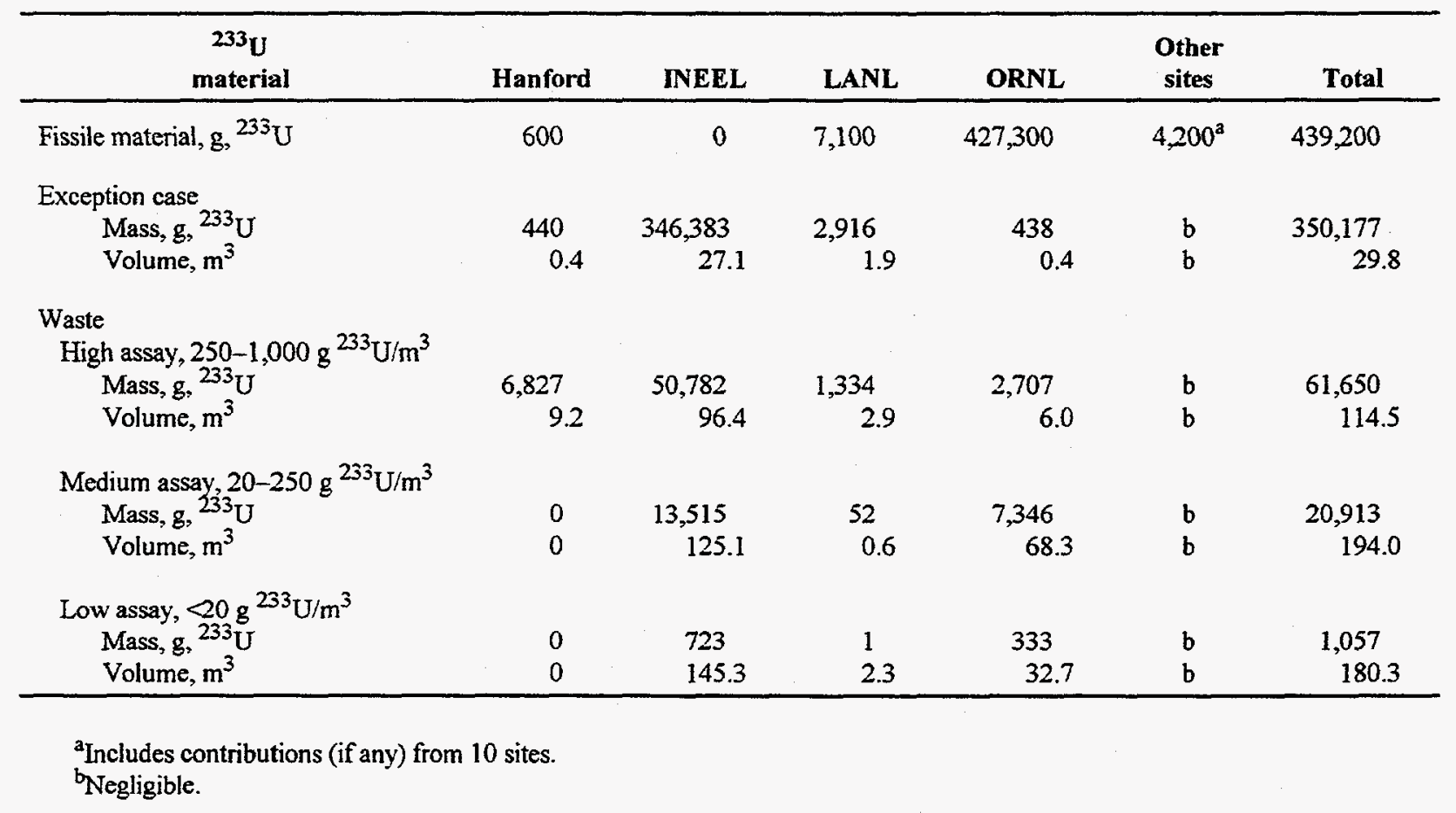


Certain ${ }^{233} U$-containing materials are excluded from this inventory. SNF with ${ }^{233} U$ is excluded. TRUW that contains plutonium and ${ }^{233} \mathrm{U}$ is excluded. This is considered TRUW and is managed as TRUW. Last, ${ }^{233} \mathrm{U}$ wastes that are low-level wastes suitable for shallow-land disposal ( $\left.<100 \mathrm{nCi}{ }^{233} \mathrm{U} / \mathrm{g}\right)$ are excluded. The ${ }^{233} \mathrm{U}$ content of these wastes are much lower than any materials in the above inventory. 


\section{INTRODUCTION}

\subsection{OBJECTIVES}

The objective of this report is to develop a set of criteria to define what ${ }^{233} \mathrm{U}$-containing materials can be managed as waste and what ${ }^{233} \mathrm{U}$-containing materials must be managed as concentrated fissile materials. The U.S. Department of Energy (DOE) inventory of ${ }^{233} \mathrm{U}$-containing materials includes materials that vary from pure ${ }^{233} \mathrm{U}$ metal to scrap containing only a few parts per million (ppm) of ${ }^{233} \mathrm{U}$. The requirements for storage, transport, and disposal of wastes are significantly different than those of concentrated fissile materials. For pure fissile materials, which can be used for the construction of nuclear weapons, there are special safeguards and security requirements to prevent theft of fissile materials for illicit construction of nuclear weapons. Wastes are stored, processed, transported, and disposed of in facilities which were not designed for and do not have weapons-usable fissile-material security systems. Because of these differences, it is important to classify appropriately what material is fissile material and what is waste. The definitions of what is waste and what is concentrated fissile material will provide guidance in appropriate management of these materials.

Wastes are defined in this report as materials containing sufficiently small masses or low concentrations of fissile materials, that, they can be treated as any other radioactive waste. Concentrated fissile materials are defined herein as materials containing sufficient fissile materials that special handling is required to address nuclear criticality, safeguards, and arms-control concerns. Certain concentrated fissile materials may have no uses and are excess material to be disposed of; however, they are not defined as wastes in the context of this report because they must be managed as concentrated fissile materials.

\subsection{CAVEAT}

There is one important caveat. Now, because of the end of the cold war, the definitions of what is waste and what is concentrated fissile material are being reexamined for both plutonium and highly-enriched uranium (HEU). Decisions made about these materials may impact the definition of ${ }^{233} U$ wastes and ${ }^{233} U$ fissile materials. 


\subsection{CHARACTERISTICS OF ${ }^{233} \mathrm{U}$}

Uranium-233 has some of the characteristics of plutonium, some of the characteristics of HEU, and some unique characteristics. Some considerations apply to the definition of waste and concentrated fissile material for any fissile-containing material; however, the same dividing line can not be used for all fissile materials because of the varying characteristics of each fissile material. A brief description of the characteristics of ${ }^{233} \mathrm{U}$ vs plutonium and HEU is provided to enable understanding of what information about plutonium and HEU is applicable to ${ }^{233} \mathrm{U}$. Table 1.1 shows the characteristics of ${ }^{233} \mathrm{U}$ as compared to those of the other two weapons-usable materials-weapons-grade plutonium (WGP) and HEU.

As a weapons material, ${ }^{233} \mathrm{U}$ is similar to WGP. The International Atomic Energy Agency (IAEA) (1993) defines Category I quantities of weapons-usable materials as $2 \mathrm{~kg}$ of WGP, $2 \mathrm{~kg}$ of ${ }^{233} \mathrm{U}$, and $5 \mathrm{~kg}$ of HEU. The Category I quantity is that quantity of material requiring nuclear weapons-type security (guns, gates, and guards) to prevent theft of the materials. Uranium-233 can be converted to non-weaponsusable uranium by isotopically diluting it with depleted uranium (DU) to $<12 \mathrm{wt} \%$ (Forsberg 1998). The comparable number for ${ }^{235} \mathrm{U}$ in HEU is $20 \mathrm{wt} \%$.

For geological disposal, the required isotopic concentration (Elam 1997) of ${ }^{233} \mathrm{U}$ in ${ }^{238} \mathrm{U}$ to minimize the potential of nuclear criticality is $0.66 \mathrm{wt} \%{ }^{233} \mathrm{U}$ when diluted with pure ${ }^{238} \mathrm{U}$ or $0.53 \mathrm{wt} \%{ }^{233} \mathrm{U}$ when diluted with DU containing $0.2 \mathrm{wt} \%{ }^{235} \mathrm{U}$. This is equivalent to $1 \mathrm{wt} \%{ }^{235} \mathrm{U}$ in ${ }^{238} \mathrm{U}$.

Uranium-233 has radiological characteristics closer to WGP than to HEU. Like WGP, ${ }^{233} U$ must be handled in an alpha containment enclosure. Unlike ${ }^{235} \mathrm{U}$ and plutonium, most of the ${ }^{233} \mathrm{U}$ contains the uranium impurity ${ }^{232} \mathrm{U}$ in concentrations sufficient to require special handing facilities-hot cells or shielded glove boxes with gamma shielding - because of higher radiation levels. The total quantities of separated ${ }^{233} \mathrm{U}$ are sufficiently large $(-2 \mathrm{t})$ such that processing is a major concern, but facilities designed to process other fissile materials can not handle ${ }^{233} U$ because of the higher radiation levels. Because large-scale use of ${ }^{233} \mathrm{U}$ was never implemented, major facilities for processing these materials were never built. This situation is in contrast to WGP and HEU, for which facilities exist to process large quantities of these materials.

\subsection{HISTORY}

Historically, a clear division between most wastes and concentrated fissile materials has existed. This division was based on economic criteria for materials containing HEU and plutonium. These fissile materials are required for the manufacture of nuclear weapons and were in short supply during the cold war. 
Table 1.1. Relative characteristics of weapons-usable materials

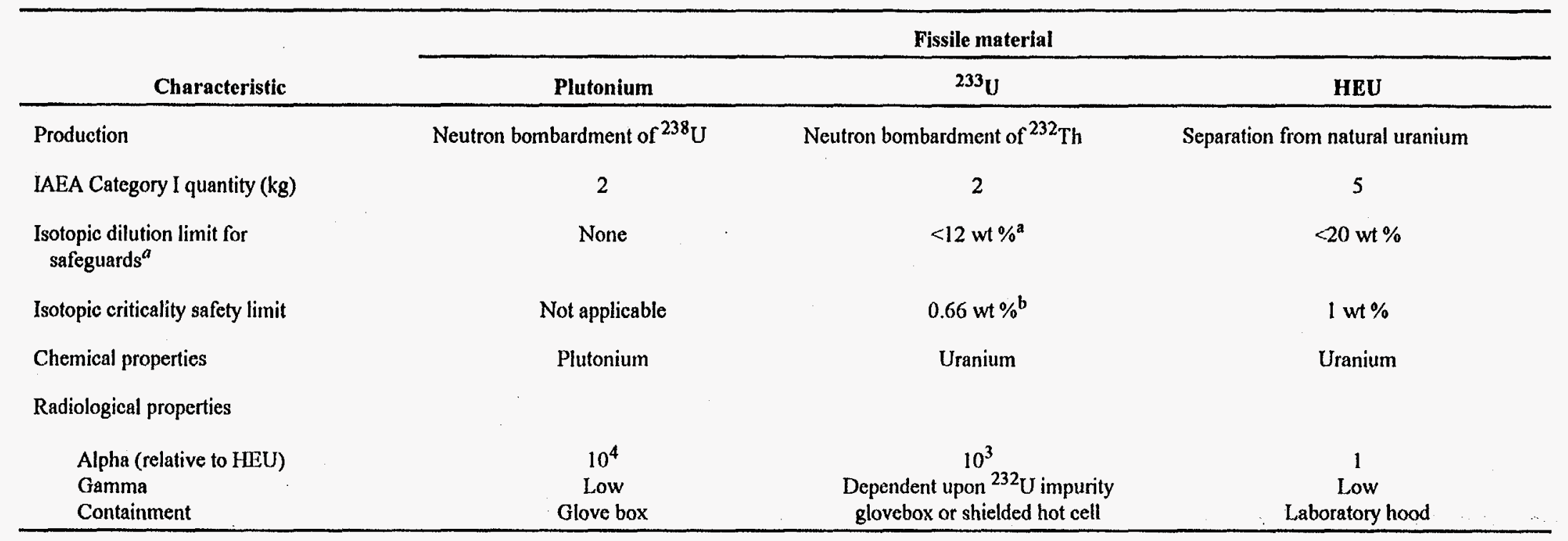

"No IAEA agreed-to isotopic dilution requirement to convert ${ }^{233} \mathrm{U}$ to non-weapons-usable material. Isotopic dilution refers to diluting ${ }^{233} \mathrm{U}$ with ${ }^{238} \mathrm{U}$. Calculations indicate that isotopic dilution of ${ }^{233} \mathrm{U}$ with ${ }^{258} \mathrm{U}$ to $\sim 12 \mathrm{wt} \%$ is equivalent to $20 \mathrm{wt} \%{ }^{235} \mathrm{U}$ in ${ }^{238} \mathrm{U}$ (Forsberg 1998).

$b_{\text {Isotopic dilution of }{ }^{233} \mathrm{U} \text { with }}{ }^{238} \mathrm{U}$ to this limit minimizes the potential for nuclear criticality in disposal facilities (Elam 1997). 
For any scrap and residue stream, a material was considered waste if the cost of the recovery of any fissile material exceeded the cost of producing new fissile material. If clean fissile materials could be recovered from the scrap and residue stream for less than the cost of producing new material, the stream was considered fissile material.

$\mathrm{HEU}$, plutonium, and ${ }^{233} \mathrm{U}$ are the three fissile materials that can be produced in large quantities to use in nuclear weapons. Uranium-233 has been investigated for use in nuclear weapons, as a fuel for nuclear reactors, and for other purposes. However, large-scale use was never implemented. Because there was no need, economic criteria to divide ${ }^{233} \mathrm{U}$-containing materials into a fissile material category and a waste category were never developed.

The unique history of ${ }^{233} \mathrm{U}$ has implications in terms of institutional issues. U.S. laws, regulations (including DOE Orders), and standards have been developed as needs were identified. The large quantities and large-scale use of WGP, low-enriched uranium (LEU), and HEU have driven the creation of facilities and institutional structures designed to specifically address issues associated with these materials. For example, the Waste Isolation Pilot Plant (WTPP) was designed for disposal of transuranic wastes (TRUWs) from plutonium and higher actinide processing facilities. In addition to the facilities, legal and regulatory structures for the management of TRUW have been created. The quantities of ${ }^{233} \mathrm{U}$ are sufficiently small such that it would be cost-prohibitive to build new special facilities and a separate institutional framework for this material. In many cases, existing and proposed facilities, such as WIPP, are technically usable for disposition of ${ }^{233} \mathrm{U}$, but the management of ${ }^{233} \mathrm{U}$ was not considered when laws, regulations, and standards for these facilities were developed. Consequently, a set of institutional issues that are unique to ${ }^{233} \mathrm{U}$ must be addressed.

\subsection{CURRENT ISSUES}

Following the end of the cold war and with accompanying surplus fissile materials, the economic criteria used to divide fissile material from waste no longer exists. With surplus fissile material, the value of the fissile material may be zero or negative. A new basis to categorize concentrated fissile materials and waste has not yet been fully developed for plutonium, HEU, or ${ }^{233} \mathrm{U}$. Three new issues now impact the definition of wastes and fissile materials.

- Domestic safeguards. Fissile materials must be guarded to prevent theft by domestic or international terrorists. Existing and proposed waste-management processing, storage, transport, and disposal facilities are not designed as high-security facilities to prevent theft of these weapons-usable materials. To be considered as a waste, the fissile content must be sufficiently low such that it is not an attractive target for theft. In the past, the economic criteria often resulted in such low concentrations of fissile materials in waste that domestic safeguards was not a constraint. 
- Arms control and international safeguards. The United States has implemented a new post-coldwar national policy to encourage worldwide reductions in inventories of weapons-usable materials. The objectives include mutually verifiable reductions in weapons-usable fissile materials with Russia. As part of this policy, the United States has proposed to convert excess weapons-usable material into a form that makes recovery of weapons-usable material difficult. The final form must meet the spent fuel standard for disposal of fissile materials. The spent fuel standard states that excess weapons-usable materials should be no more accessible for use in nuclear weapons than is plutonium found in commercial nuclear-power reactor spent nuclear fuel (SNF). To obtain agreement with Russia, the same rules would apply to both countries.

These arms control considerations imply that the wastes containing fissile materials may be required to meet the spent fuel standard; otherwise, any country could adopt waste management policies that declare fissile materials as waste and bypass the intent of proposed arms-control treaties that limit weapons-usable fissile-material inventories. No policy decisions have yet been made on the applicability of the spent fuel standard to different types of waste.

- Nuclear criticality in disposal facilities. Regulatory and performance requirements for disposal sites require that nuclear criticality be avoided (1) during the operational phase of the facility and (2) after disposal site closure. Fissile materials may migrate within a disposal facility over time. Waste-form composition and special facility design features are required to avoid nuclear criticality. The historical economic definition of waste implied low-concentrations of fissile materials in the wastes. Facilities were designed on this basis. Evaluation of criticality issues associated with higher fissile assay wastes may be required.

\subsection{CATEGORIZATION OF ${ }^{233}$ U CONTAINING MATERIALS}

The end of the cold war has necessitated a rethinking of the line separating wastes from fissile materials. However, many of the technical and institutional issues have not yet been resolved at the level of detail to allow for the drawing of a single, new, dividing line between concentrated fissile materials and wastes.

The approach used herein to address this difficulty is to divide ${ }^{233} \mathrm{U}$ containing materials into three categories: concentrated fissile materials, exception-case materials, and wastes. Concentrated fissile materials contain ${ }^{233} U$ in concentrations sufficient that tight controls are needed to avoid nuclear criticality, security is required to prevent theft, and the material may be important in arms-control treaties. Wastes are defined as having sufficiently low concentrations of ${ }^{233} U$ such that nuclear criticality, safeguards, and arms control are not significant issues. Exception-case materials have ${ }^{233} U$ concentrations sufficiently high such that they may have some properties of waste and some properties of concentrated fissile material. How they are ultimately managed depends upon resolution of the above issues. The basis for these three categories are developed in this report. 
The categorization of a batch of material containing ${ }^{233} \mathrm{U}$ as exception-case material does not change how it is managed today. It does, however, flag the material and indicate that resolution of various fissile material management issues may alter how this material is managed in the future. In many cases, decisions made on the management of plutonium scrap and residue will resolve uncertainties associated with management of exception-case material.

\subsection{REPORT ORGANIZATION}

Section 2 of this document describes the current inventory of ${ }^{233} U$-containing materials. In Sect. 3 , waste disposal and fissile-material disposition options for ${ }^{233} \mathrm{U}$-containing material are described. Sections 4 and 5 present an evaluation of the unique issues with the management of fissile materials: nuclear criticality (Sect. 4) and safeguards (Sect. 5). Section 6 summarizes of the conclusions. 


\section{INVENTORY OF ${ }^{233} \mathrm{U}-\mathrm{BEARING}$ MATERIALS}

\subsection{INTRODUCTION}

Domestic inventories of ${ }^{233} \mathrm{U}$-bearing materials are given in Table 2.1. Most of these inventories are reported for four major DOE sites: Idaho National Engineering and Environmental Laboratory (INEEL), Oak Ridge National Laboratory (ORNL), Los Alamos National Laboratory (LANL), and the Hanford Site (Hanford). Inventories of ${ }^{233} \mathrm{U}$ materials at other sites are also listed as an aggregate.

Table 2.1 also shows the breakdown of the domestic inventory for three ${ }^{233} \mathrm{U}$-bearing material categories: fissile materials, exception-case materials, and wastes. The basis for this division is discussed in this report, and definitions of the ${ }^{233} \mathrm{U}$-bearing material categories are provided in Sect. 1.

\subsection{CONCENTRATED FISSILE MATERIAL (NONWASTE) INVENTORY}

Table 2.2 (Bereolos et al. June 1998) reports the summary inventories of DOE fissile ${ }^{233} \mathrm{U}$-bearing materials. Separate inventories are listed for Hanford, INEEL, LANL, and ORNL. The remaining fissile inventory is comprised of small contributions from 10 other sites. ORNL has the largest fissile inventory, which includes material from the Consolidated Edison Uranium Solidification Program.

\subsection{EXCEPTION-CASE MATERIAL INVENTORY}

\subsubsection{Introduction}

Most of the domestic exception-case material is stored as a ${ }^{233} \mathrm{U}$-thorium mixture at INEEL. This material is a mix of thorium oxide $\left(\mathrm{ThO}_{2}\right)$ and uranium dioxide $\left(\mathrm{UO}_{2}\right)$ with $2-12 \mathrm{wt} \%{ }^{233} \mathrm{U}$ (as measured with respect to total mass). Table 2.3 provides a summary of INEEL exception-case material (based on Lockheed Martin Idaho Technologies Company November 12-14, 1996; Detrick May 6, 1997; Sadler June 10, 1997; Mitchell, Semans, and Smith October 1974; Schick et al. September 1987; and Hammond March 13, 1998), most of which is unirradiated light-water breeder reactor (LWBR) fuel. There is a natural divide in the total ${ }^{233} \mathrm{U}$ inventory between this LWBR material and the rest of the inventory. Other exception-case material is found at Hanford and LANL (Drez March 20, 1998). Detailed characteristics of this material are described in the following. 
Table 2.1. Inventories of ${ }^{233} \mathrm{U}$-bearing materials

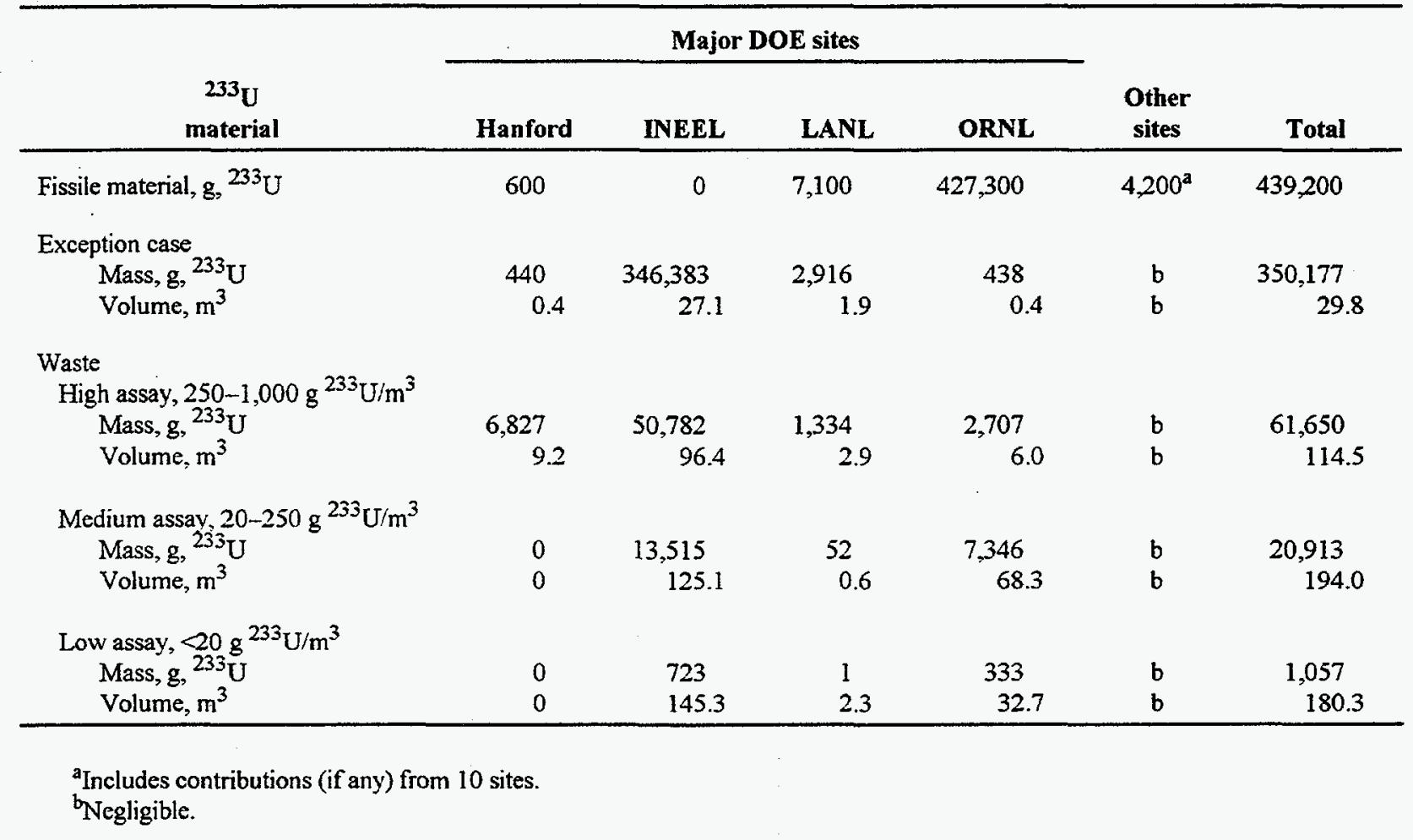

Table 2.2. Summary, by major sites, of domestic ${ }^{233} U$ fissile material (nonwaste) characteristics and inventories $^{\mathrm{a}}$

\begin{tabular}{lcccc}
\hline \multicolumn{1}{c}{ Site } & $\begin{array}{c}\text { No. of } \\
\text { packages }\end{array}$ & $\begin{array}{c}\text { Total } \mathbf{U} \\
(\mathbf{k g})\end{array}$ & $\begin{array}{c}{ }^{233} \mathbf{U} \\
(\mathbf{k g})\end{array}$ & $\begin{array}{c}\mathbf{2 3 5}_{\mathbf{U}} \\
(\mathbf{k g})\end{array}$ \\
\hline INEEL & 0 & 0 & 0 & 0 \\
ORNL & 1,049 & $1,387.7$ & 427.3 & 796.3 \\
Others & -270 & -54.4 & 11.9 & 38.7 \\
\multicolumn{1}{c}{ Totals } & 1,319 & $1,442.1$ & 439.2 & 835.0 \\
\hline
\end{tabular}

${ }^{2}$ Adapted from Bereolos et al. June 1998. Excludes materials that are categorized as waste or SNF that may be candidate ${ }^{233} \mathrm{U}$ materials after recovery or separation.

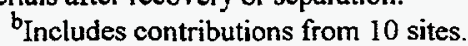


Table 2.3. INEEL exception-case material ${ }^{\mathrm{a}}$

\begin{tabular}{lcc}
\hline \multicolumn{1}{c}{ Category } & $\begin{array}{c}\text { Volume } \\
\left(\mathbf{m}^{\mathbf{3}}\right)\end{array}$ & $\begin{array}{c}\mathbf{2 3 3} \mathbf{U} \text { mass } \\
(\mathbf{g})\end{array}$ \\
\hline Unirradiated LWBR fuel & 4.9 & 317,364 \\
Storage boxes in buildings & 11.2 & 14,707 \\
Drums under earthen cover berms & 11.0 & 14,312 \\
$\quad$ Totals & 27.1 & 346,383 \\
\hline
\end{tabular}

${ }^{2}$ Based on Detrick May 6, 1997; Sadler June 10, 1997; Mitchell, Semans, and Smith October 1974; Schick et al. September 1987; Hammond March 13, 1998; and Lockheed Martin Idaho Technologies Company November 12-14, 1996.

\subsubsection{LWBR Fuel}

The largest inventory of exception-case material is the unirradiated Shippingport LWBR fuel, which is stored at the INEEL Idaho Chemical Processing Plant (ICPP) LWBR Fuel Storage Facility (CPP-749) in 21 underground dry storage vaults. A summary of the inventory characteristics of the LWBR fuel is provided in Tables 2.4 and 2.5. Table 2.4 lists the canisters shipped from Bettis Atomic Power Laboratory that are stored in 20 dry storage vaults, and Table 2.5 gives the characteristics of a spare unirradiated LWBR seed module that is canned and stored in a separate vault.

As shown in Figs. 2.1 and 2.2 (from Bolton, Christiansen, and Hallinan March 1989), each unirradiated LWBR fuel dry storage vault is sized to allow two stacked storage canisters containing LWBR fuel rods to be loaded end to end. Each storage canister has an outer diameter (OD) of 8.625 in. and an outer length of $10 \mathrm{ft} ., 4.75 \mathrm{in}$.

Shorter breeder mock-up (BMU) fuel rods are packed into smaller canisters, as shown in the lower half of Fig. 2.2. These inner canisters are loaded into a storage canister. An inner canister has a 7.5-in. OD and an outer length that can vary from 29.75 in. for storage of BMU seed rods to $44.25 \mathrm{in}$. for storage of BMU blanket rods. A storage canister can contain various combinations of inner canisters. The Final Safety Analysis Report (FSAR) (Bolton, Christiansen, and Hallinan March 1989) for the unirradiated LWBR fuel at INEEL indicates that two inner canisters containing 42-in.-long BMU blanket rods and one inner canister containing 24-in.-long BMU seed rods were placed into a storage canister if uranium content in the seed rods exceeded $5 \mathrm{wt} \%$. If the uranium content in the BMU seed rods was $\leq 5 \mathrm{wt} \%$, then two BMU seed canisters and one blanket canister were placed in a storage canister. The FSAR indicates that this procedure was followed to average the uranium loading per storage canister. 
Table 2.4. Exception-case material: storage locations and contents of BAPL container shipments of unirradiated LWBR fuel to the INEEL-ICPPa

\begin{tabular}{|c|c|c|c|c|c|c|c|c|c|c|c|}
\hline \multirow{2}{*}{$\begin{array}{c}\text { ID of } \\
\text { dry storage } \\
\text { vault }^{\mathbf{b}}\end{array}$} & \multirow[b]{2}{*}{ Position $^{\mathrm{c}}$} & \multirow{2}{*}{$\begin{array}{c}\text { ID of } \\
\text { stored shipping } \\
\text { container }^{\mathrm{d}}\end{array}$} & \multicolumn{2}{|c|}{ Rods } & \multirow{2}{*}{$\begin{array}{c}{ }^{233} \mathrm{U} \\
\text { content } \\
(\mathrm{g}) \\
\end{array}$} & \multirow{2}{*}{$\begin{array}{c}\text { ID of } \\
\text { dry storage } \\
\text { vault }^{\mathrm{b}}\end{array}$} & \multirow[b]{2}{*}{ Position $^{c}$} & \multirow{2}{*}{$\begin{array}{c}\text { ID of } \\
\text { stored shipping } \\
\text { container }^{\mathbf{d}}\end{array}$} & \multicolumn{2}{|c|}{ Rods } & \multirow{2}{*}{$\begin{array}{c}{ }^{233} \mathrm{U} \\
\text { content } \\
\text { (g) }\end{array}$} \\
\hline & & & Type(s) & Number ${ }^{f}$ & & & & & Type(s) ${ }^{e}$ & Number ${ }^{f}$ & \\
\hline \multirow[t]{2}{*}{ U-I } & Top & LWB-04 & S, B & 744 & 9,032 & \multirow[t]{2}{*}{ U-11 } & Top & LWB-25 & $\mathrm{s}$ & 476 & 11,934 \\
\hline & Bottom & LWB-11 & S, B & 749 & 11,832 & & Bottom & LWB-38 & $\mathrm{B}, \mathrm{PFB}$ & 156 & 9,324 \\
\hline \multirow{2}{*}{$\mathrm{U} \cdot 2$} & Top & LWB-05 & S, B & 746 & 9,066 & \multirow[t]{2}{*}{ U-12 } & Top & LWB-24 & $\mathrm{B}, \mathrm{PFB}$ & 148 & 7,061 \\
\hline & Bottom & LWB-13 & S, B & 738 & 11,927 & & Bottom & LWB-17 & $\mathrm{B}, \mathrm{PFB}$ & 143 & 6,056 \\
\hline \multirow[t]{2}{*}{ U.3 } & Top & LWB-02 & S, B & 762 & 8,132 & \multirow[t]{2}{*}{ U-13 } & Top & LWB-31 & $\mathrm{B}, \mathrm{PFB}$ & 149 & 6,709 \\
\hline & Bottom & LWB-14 & S, B & 742 & 11,993 & & Bottom & LWB-28 & $\mathrm{S}, \mathrm{B}, \mathrm{PFB}$ & 250 & 7,760 \\
\hline \multirow[t]{2}{*}{$\mathrm{U}-4$} & Top & LWB-01 & S, B & 738 & 9,003 & \multirow[t]{2}{*}{ U-14 } & Top & LWB-37 & $\mathrm{B}, \mathrm{PFB}$ & 147 & 5,198 \\
\hline & Bottom & LWB-15 & S, B & 707 & 11,520 & & Bottom & LWB-32 & $\mathrm{B}, \mathrm{PFB}$ & 151 & 4,299 \\
\hline \multirow[t]{2}{*}{ U.5 } & Top & LWB-08 & S, B & 1,232 & 6,015 & \multirow[t]{2}{*}{ U-15 } & Top & LWB-18 & S, B, PFB & 243 & 7,562 \\
\hline & Bottom & LWB-03 & $\mathrm{S}, \mathrm{B}$ & 747 & 5,349 & & Bottom & LWB-19 & $\mathrm{S}, \mathrm{B}$ & 177 & 5,747 \\
\hline \multirow[t]{2}{*}{ U.6 } & Top & LWB-16 & B & 136 & 4,371 & \multirow[t]{2}{*}{ U-16 } & Top & LWB-30 & $\mathrm{S}, \mathrm{B}, \mathrm{PFB}$ & 183 & 5,270 \\
\hline & Bottom & LWB-09 & S, B & 759 & 4,086 & & Bottom & LWB-21 & S, B, PFB & 271 & 8,459 \\
\hline \multirow{2}{*}{ U-7 } & Top & LWB-39 & $\mathrm{B}, \mathrm{PFB}$ & 139 & 3,562 & \multirow[t]{2}{*}{$U-17$} & Top & LWB-26 & S, B, PFB & 180 & 6,097 \\
\hline & Bottom & LWB-36 & PFB & 159 & 8,768 & & Bottom & LWB-23 & S, B, PFB & 263 & 10,114 \\
\hline \multirow[t]{2}{*}{ U-8 } & Top & LWB-35 & S, PFB & 261 & 8,572 & \multirow[t]{2}{*}{ U-18 } & Top & LWB-33 & $\mathrm{S}, \mathrm{B}, \mathrm{PFB}$ & 178 & 6,464 \\
\hline & Bottom & LWB-34 & $\mathrm{s}$ & 462 & 10,493 & & Bottom & LWB-29 & $\mathrm{S}, \mathrm{B}, \mathrm{PFB}$ & 185 & 5,360 \\
\hline \multirow[t]{2}{*}{ U-9 } & Top & LWB-07 & $\mathrm{B}, \mathrm{PFB}$ & 149 & 7,438 & \multirow[t]{2}{*}{ U-19 } & Top & LWB-22 & $\mathrm{S}, \mathrm{B}, \mathrm{PFB}$ & 346 & 8,293 \\
\hline & Boftom & LWB-06 & $\mathrm{B}, \mathrm{PFB}$ & 155 & 8,074 & & Bottom & LWB-20 & $\mathrm{B}, \mathrm{PFB}$ & 150 & 7,401 \\
\hline \multirow[t]{3}{*}{ U-10 } & Top & LWB-40 & B & 134 & 5,500 & \multirow[t]{3}{*}{ U-20 } & Top & LWB-42 & \multirow{2}{*}{$\begin{array}{l}\mathrm{S}, \mathrm{B}, \mathrm{PFB}, \mathrm{R}, \mathrm{M} \\
\mathrm{M}\end{array}$} & 122 & 3,339 \\
\hline & Bottom & LWB-27 & $\mathrm{B}, \mathrm{PFB}$ & 153 & 6,712 & & Bottom & LWB-41 & & 138 & 6,909 \\
\hline & & & & & & & & & Totals & 14,468 & 300,801 \\
\hline
\end{tabular}

abased on Detrick May 6, 1997 and April 8, 1998, and Sadler June 10, 1997.

bry wells located at the INEEL-ICPP Unirradiated LWBR Fuel Storage Area (Facility 749).

${ }^{c}$ Each dry storage vault has space for two storage containers, one stacked on top of the other. Each storage container has an outer circular diameter of $8-5 / 8$ in. and an outer length of $10 \mathrm{ft}$ 4-3/4 in.

${ }^{\mathrm{d}}$ Dimensions of shipping containers are indicated in Figs. 2.1 and 2.2 .

'Types of rods: seed (S), standard blanket (B), power-flattening blanket (PFB), reflector (R), and miscellaneous (M)

Total number of rods (all types) in container (canister). 
Table 2.5. Exception-case material: characteristics of the spare unirradiated LWBR seed module stored in INEEL-ICPP Dry Storage Vault U-22 ${ }^{\text {a }}$

\begin{tabular}{|c|c|c|c|c|c|c|}
\hline \multirow[b]{2}{*}{$\begin{array}{c}\text { Module } \\
\text { type }\end{array}$} & \multirow[b]{2}{*}{$\begin{array}{c}\text { Rod } \\
\text { stratum }^{\mathbf{b}}\end{array}$} & \multirow[b]{2}{*}{$\begin{array}{c}{ }^{233} \mathrm{U} \\
(w t \%)^{c}\end{array}$} & \multirow[b]{2}{*}{$\begin{array}{c}\text { Number } \\
\text { of rods }\end{array}$} & \multicolumn{3}{|c|}{ Mass, $\mathrm{g}$} \\
\hline & & & & Total U & ${ }^{233} \mathrm{U}$ & Th \\
\hline \multirow[t]{7}{*}{ Seed III- $5^{d}$} & $\mathrm{H}-84$ & 5.2 & 331 & 11,642 & 11,452 & 181,923 \\
\hline & $\mathrm{L}-70$ & 4.2 & 66 & 1,606 & 1,580 & 31,457 \\
\hline & $\mathrm{L}-56$ & 4.2 & 72 & 1,402 & 1,379 & 27,455 \\
\hline & $L-42$ & 4.2 & 150 & 2,188 & 2,152 & 42,844 \\
\hline & Thoria $\left(\mathrm{ThO}_{2}\right)$ & 0 & 0 & 0 & 0 & 150,321 \\
\hline & reflectors and steps & & - & $\ldots$ & 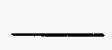 & - \\
\hline & Totals & & 619 & 16,838 & 16,563 & 434,000 \\
\hline
\end{tabular}

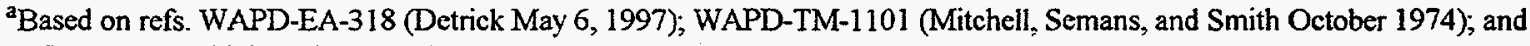
WAPD-TM-1612 (Schick et al. September 1987).

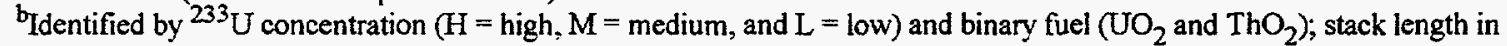
inches.

${ }^{\mathrm{c}} \mathrm{Measured}$ by $\left[{ }^{233} \mathrm{U}(\mathrm{g}) /\left(\mathrm{UO}_{2}+\mathrm{ThO}_{2}\right)(\mathrm{g})\right] \times 100 \%$. All binary fuel pellets in any given rod have the same concentration of fissile uranium.

dStored in a canister in Dry Storage Vault U-22, which is at the southern end of the INEEL-ICPP unirradiated LWBR Fuel Storage Area.

\subsubsection{INEEL Storage Drums}

Table 2.6 (Hammond March 13, 1998) lists other exception-case materials at INEEL, which are in storage at the Radioactive Waste Management Complex (RWMC). The material resides in two major types of storage facilities: a building for above-ground retrievable storage and earthen cover berms. The building contains exception-case material regarded as "accessible" in 11 overpack boxes, each of which contains 5 to $6 \mathrm{bbl}$, each having 55- or 110-gal capacity, as shown in Fig. 2.3. Each overpack box has 5/8-in.-thick lead shielding. Earthen-cover berms contain barrels of ${ }^{233} \mathrm{U}$ exception-case material that are stacked on asphalt pads. The barrels are separated by layers of plywood and plastic and backfilled under an earthen cover. A total of 1804 barrels, 107 of which contain exception-case material, are regarded as "unaccessible" and are found in the earthen-cover berms. Each of the 107 barrels contains a $2 \mathrm{R}$ vessel inside a $6 \mathrm{M}$ drum. 


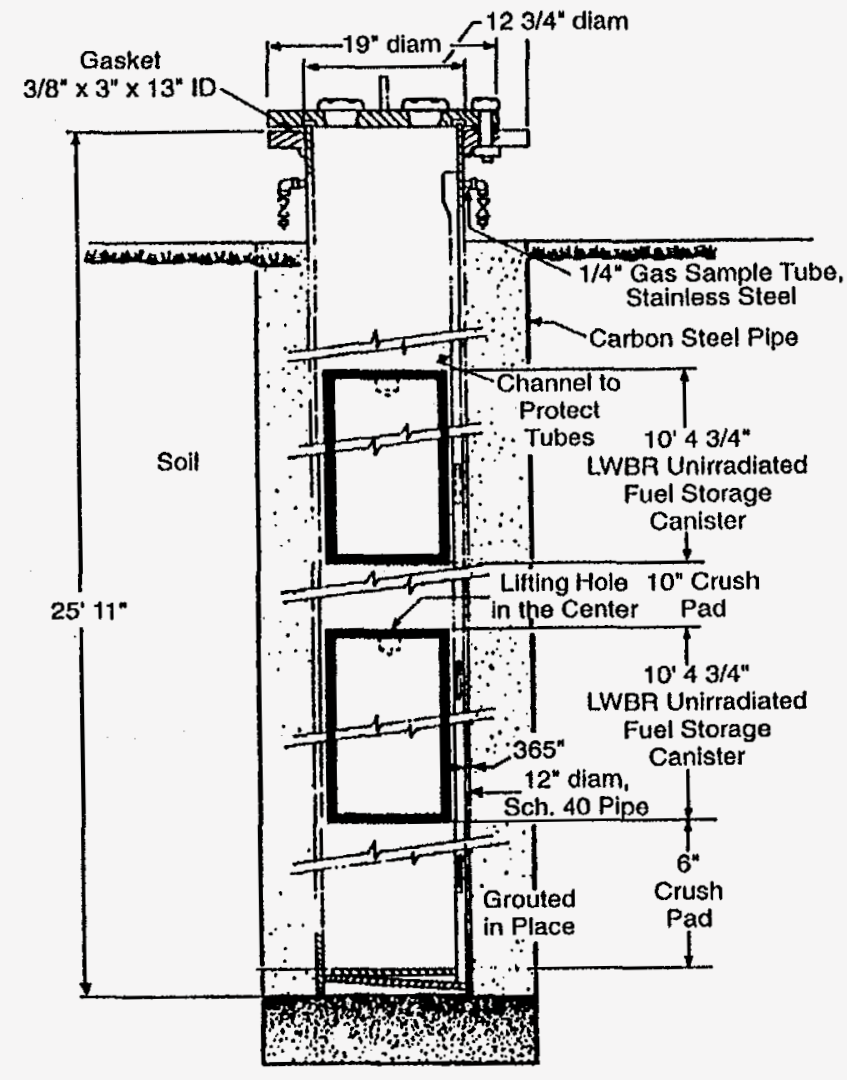

a. Unirradlated LWBR Fuel Storage Dry Vault

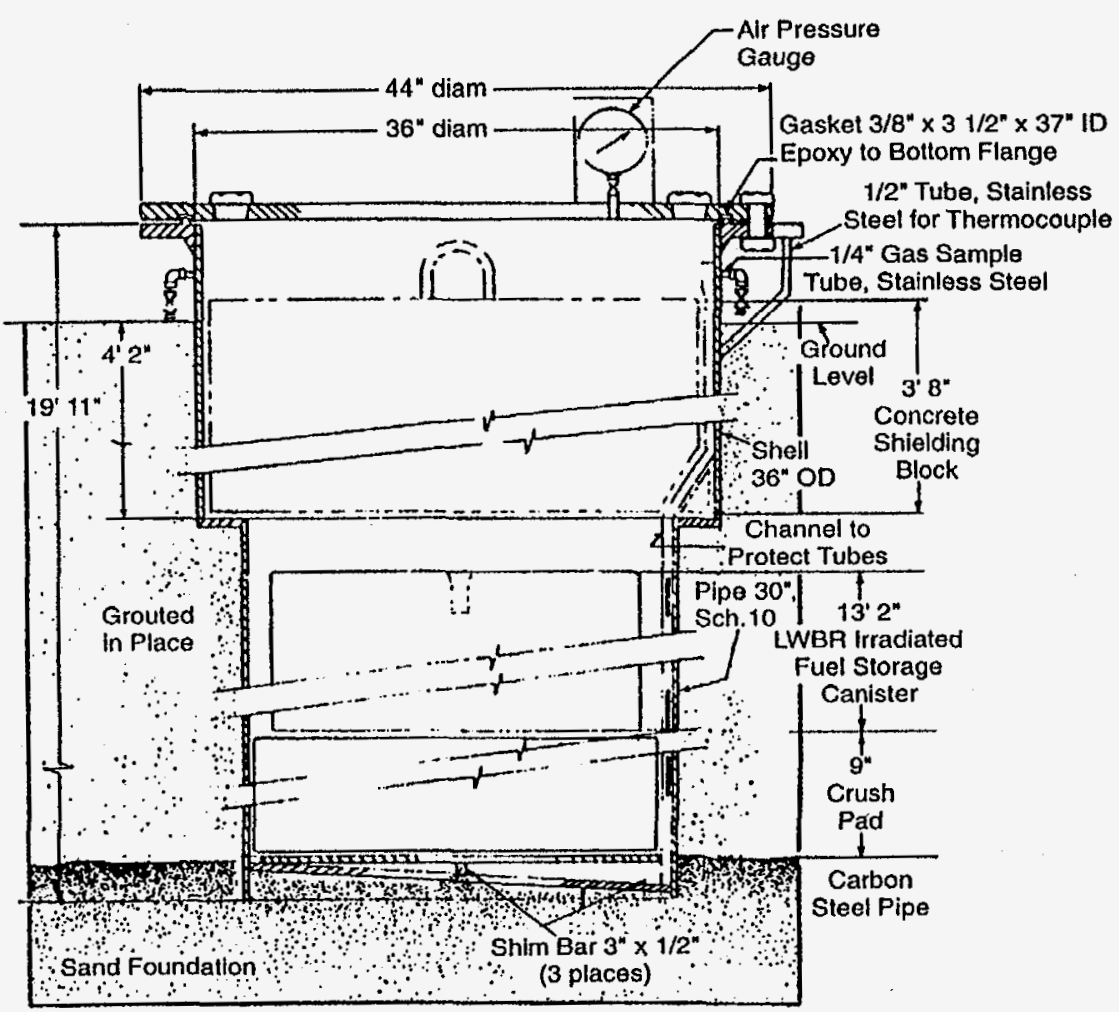

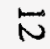

Fig. 2.1. Section views of the dry-vault design for both unirradiated (exception-case material) and irradiated LWBR fuel storage dry vaults at INEEL. The vault on the left stores the canisters of unirradiated LWBR fuel rods while the vault on the right stores both the irradiated LWBR

fuel and the single unirradiated sparc LWBR seed module. Courtesy of Idaho National Engineering and Environmental Laboratory, Idaho Falls, Idaho. 
Threaded "Lifting Rod"

Hole or Other Handling

Arrangement as Required

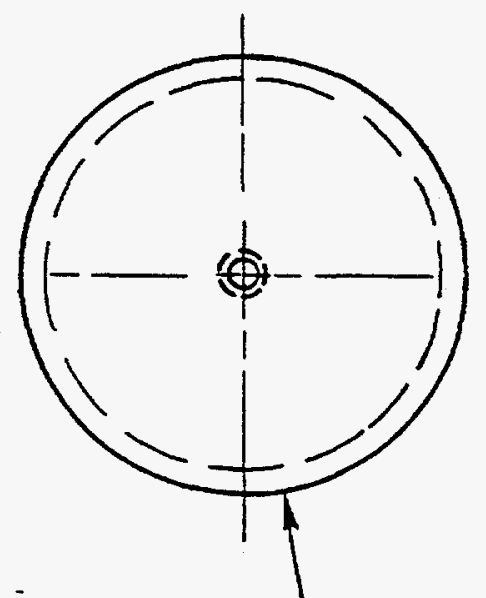

2" Thick Cover Attached with 4-3/8*

ORNL $97-123519$

Self-locking Screws - Flush on Sides

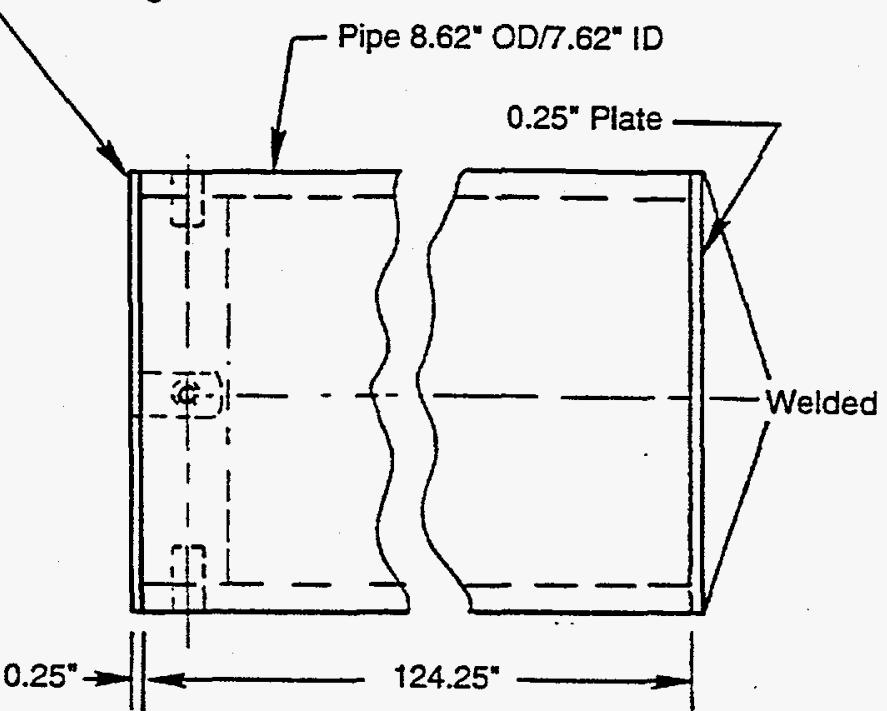

Rod Storage Container
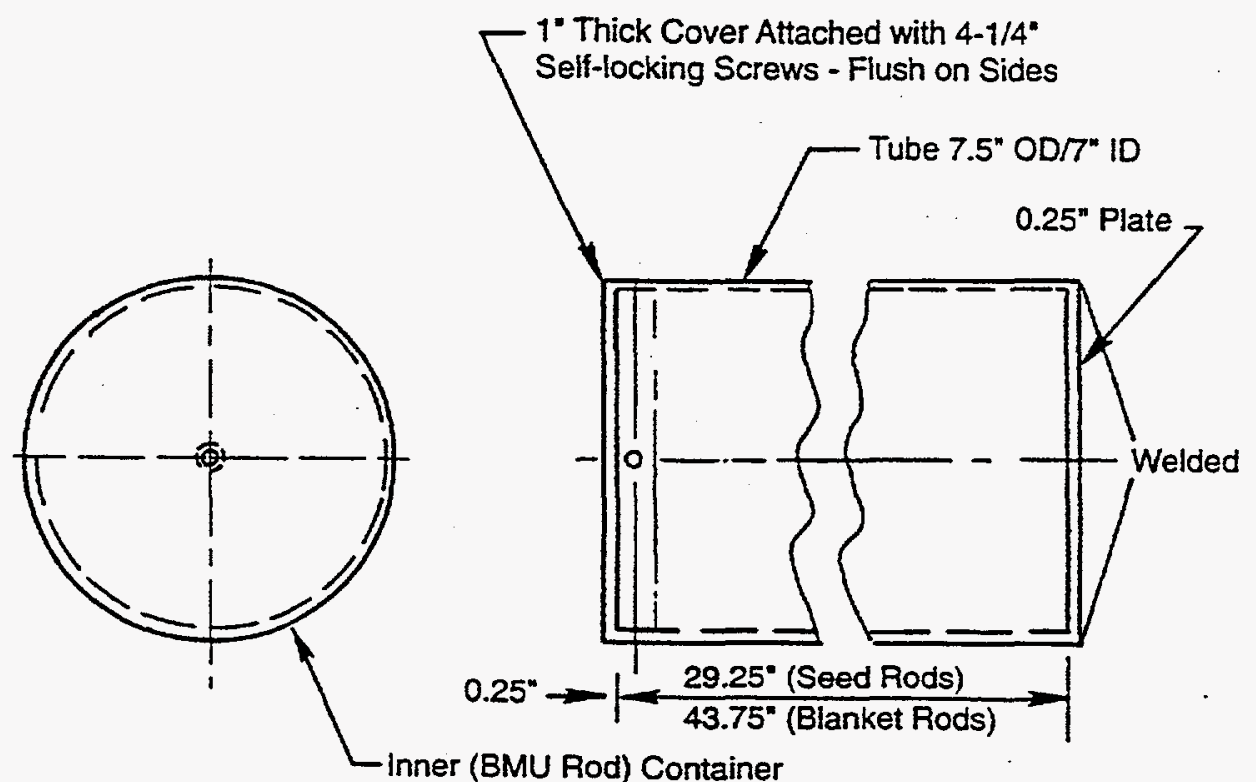

( 3 per Rod Storage Container with Metal Fillers for Snug Fit)

Fig. 2.2. Axial and radial views of storage canisters for unirradiated $L W B R$ fuel (exception-case material). Courtesy of Idaho National Engineering and Environmental Laboratory, Idaho Falls, Idaho. 
Table 2.6. Total ${ }^{233} \mathrm{U}$ wastes and other exception-case materials at INEEL ${ }^{\mathrm{a}}$

\begin{tabular}{|c|c|c|c|c|c|c|}
\hline \multirow{2}{*}{$\begin{array}{l}\text { INEEL } \\
\text { storage } \\
\text { area(s) }\end{array}$} & \multicolumn{3}{|c|}{ Total containers $^{b}$} & \multicolumn{3}{|c|}{ Exception-case material ${ }^{\mathfrak{c}}$} \\
\hline & Number & Type & ${ }^{233} \mathrm{U}$ mass, $\mathrm{g}$ & Number & Type & ${ }^{233} \mathrm{U}$ mass, $\mathrm{g}$ \\
\hline \multirow[t]{2}{*}{ Building } & 11 & Boxes $^{d}$ & 16,389 & 9 & Boxes & 14,707 \\
\hline & 47 & Drums & 3,554 & 0 & Drums & 0 \\
\hline Earthen cover berms & 1,650 & Drums & 74,100 & 53 & Drums & 14,312 \\
\hline
\end{tabular}

${ }^{3}$ Based on Hammond March 13, 1998.

bIncludes both wastes and exception-case material.

CContainers with $>200 \mathrm{~g}^{233} \mathrm{U}$.

${ }^{\mathrm{d}}$ Each of 10 boxes has 6 drums, and one additional box has 5 drums.

$A$ " $2 R$ " vessel refers to a packaged container fabricated and certified to meet U.S. Department of Transportation (DOT) Specification 2R, whose detailed requirements are based on 49 Code of Federal Regulations (CFR) Part 178.360. The particular 2R vessel that contains the INEEL exception-case berm material is the inner-vessel portion of a certified DOT Type B shipping container package that consists of a Specification $2 \mathrm{R}$ vessel encased in a DOT Specification $6 \mathrm{M}$ drum $(55$-gal). Figure 2.4 a illustrates a $2 \mathrm{R}$ container in a $6 \mathrm{M}$ overpack, and Fig. $2.4 \mathrm{~b}$ shows the cross section of a typical DOT specification $2 \mathrm{R}$ (Kelly September 1994). At the RWMC, a $2 \mathrm{R}$ container is used for material that is either fuel pellets or fuel rods. For waste material, the outer drum of Fig. $2.4 \mathrm{a}$ is a $17 \mathrm{C}$ drum and does not have the spacers or the $2 \mathrm{R}$ container.

\subsubsection{ORNL Inventory}

The ${ }^{233} \mathrm{U}$ inventory reported for ORNL excludes contributions from nearly 3200 drums that have small concentrations of ${ }^{233} \mathrm{U}$ (most of which are $<4 \mathrm{~g} / \mathrm{drum}$ ) mixed with some ${ }^{239} \mathrm{Pu}$. Collectively, these additional drums have $1.1 \mathrm{~kg}$ of ${ }^{233} \mathrm{U}$. Only 2 drums of the ORNL inventory have ${ }^{233} \mathrm{U}$ concentrations that would qualify as exception-case material. Materials in the other drums are considered waste.

The waste is made up largely of low-level waste (LLW) and TRUW, consisting of materials from contaminated areas, gloveboxes, hot cells, construction debris, personal protective equipment, piping, and used equipment. The waste forms are primarily metal, wood, plastic, glass, and cardboard. 

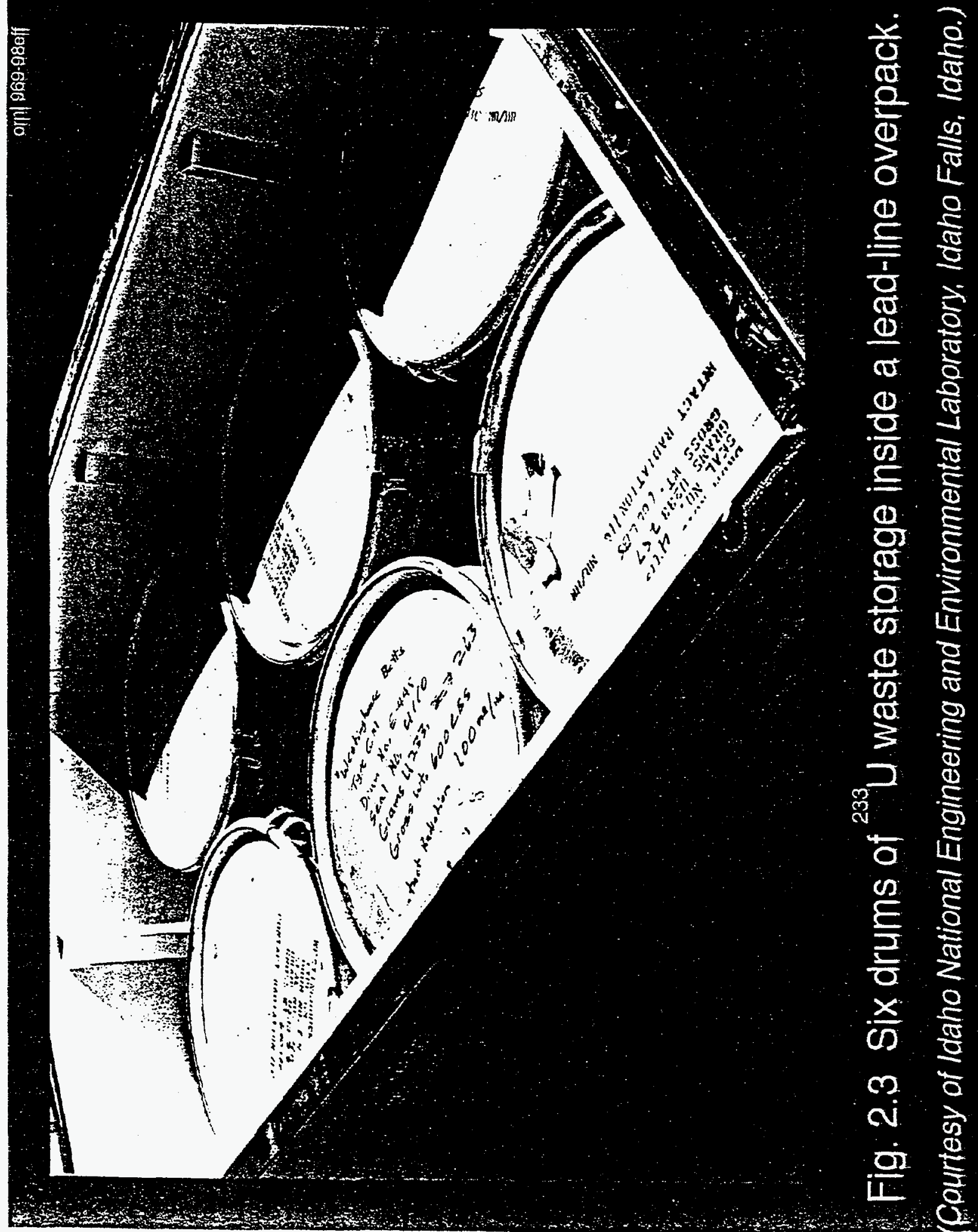


\section{DOT Specification 6M Package}

\section{(Per 49 CFR 178.354)}

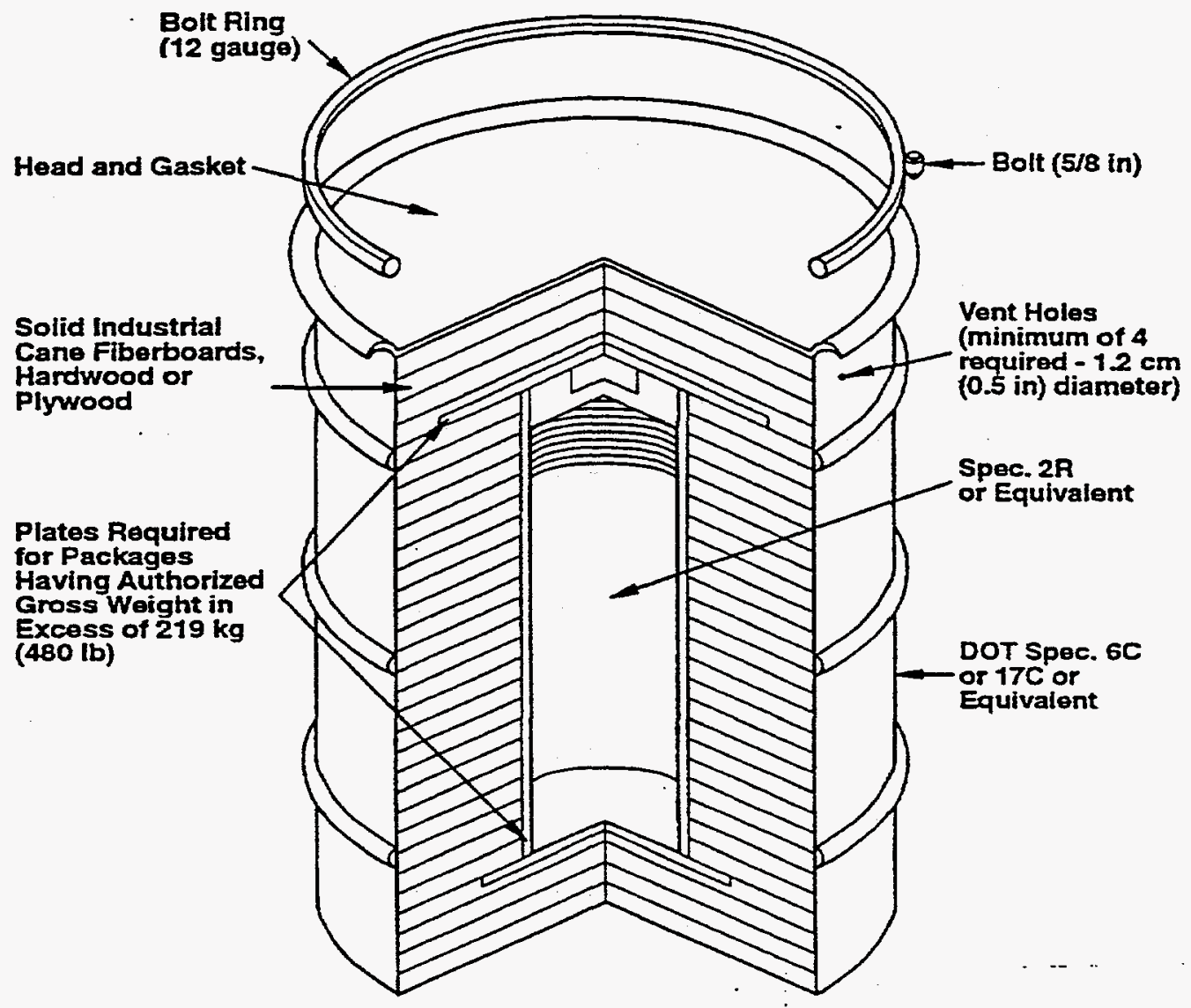

Fig. 2.4a. Typical DOT Specification 6M: a 6M overpack containing a 2R container. Courtesy of DOE, Richland Operations Office, as reported in Kelly, September 1994. 


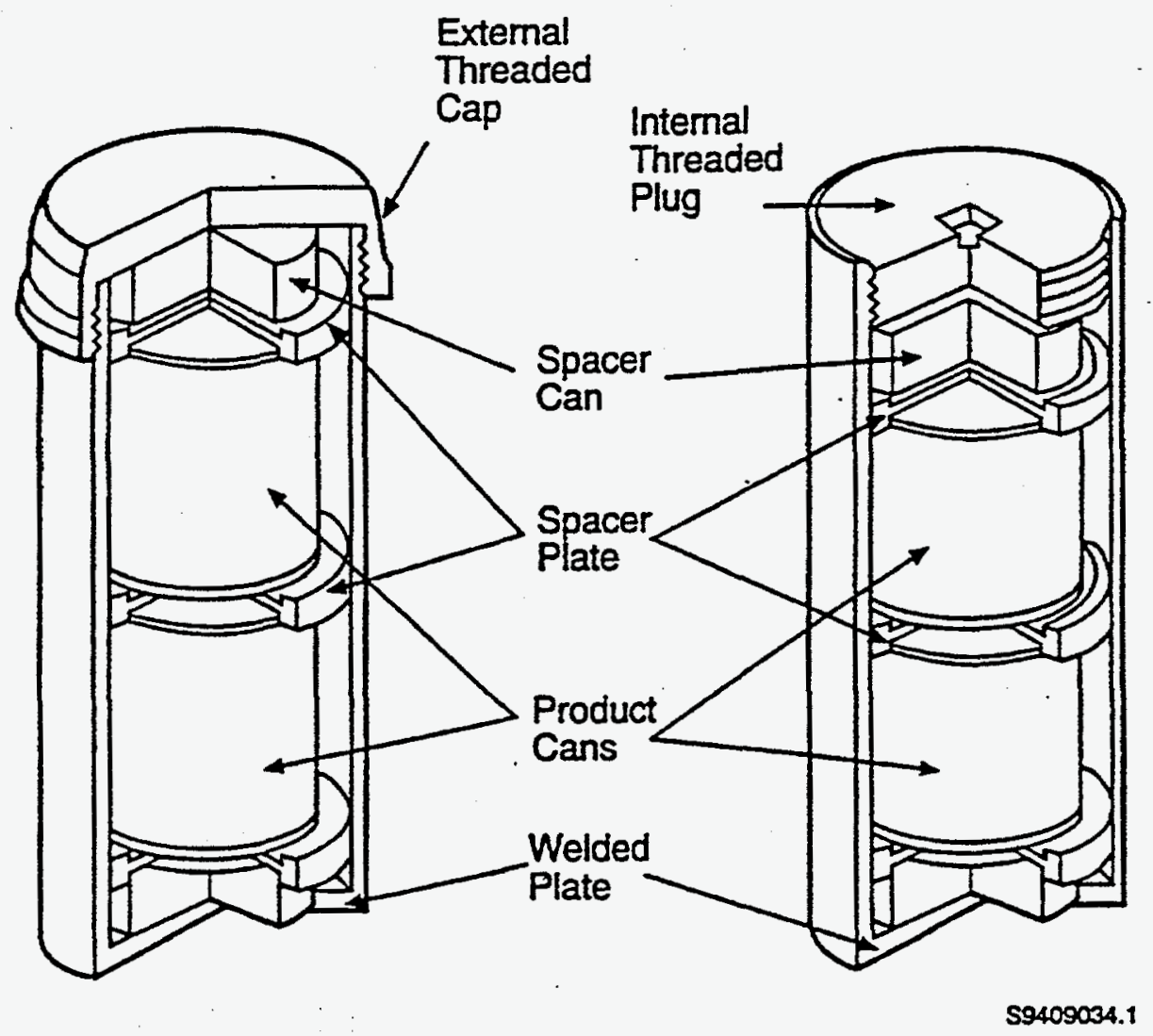

Fig. 2.4b. Typical DOT Specification 2R.

Courtesy of DOE, Richland Operations Office, as reported in Kelly, September 1994. 
Approximately $40 \%$ of the waste containers are metal $4^{\prime} \times 4^{\prime} \times 6^{\prime}$ boxes (B-25 boxes). The other common forms of waste packaging are drums ( $20 \%$ of the waste containers) and concrete vaults ( $20 \%$ of the waste containers). Approximately a third of work containers (or $75 \%$ of the ${ }^{233} \mathrm{U}$ activity) were generated by Building 3019, the ORNL Radiochemical Development Facility (RDF). Historically, this facility served as the pilot plant for radiochemical processing (primarily thorium and ${ }^{233} \mathrm{U}$ ). The RDF currently serves as the National Repository for ${ }^{233} U$ and conducts research and development (R\&D) activities in medical isotopes production from ${ }^{233} \mathrm{U}$ radioactive daughters. The remaining waste containers originated from various facilities at $O R N L$ where $R \& D$ and radioisotope processing activities were performed.

Most of the ${ }^{233} \mathrm{U}$-bearing waste at ORNL is currently stored in retrievable storage facilities. Twenty percent of the waste containers are stored in Building $7842 \mathrm{C}$, a prefabricated metal structure on a reinforced concrete pad. This facility is equipped with electricity and phone lines. Portable radiation survey equipment is used to monitor the facility for radiation levels and contamination. Twenty-eight percent of the waste containers are stored in Building 7886, the Interim Waste Management Facility (IWMF). The IWMF is an above-grade tumulus disposal facility consisting of a high density concrete, steel rebar reinforced pad with concrete vaults stacked three high. Another $20 \%$ of the waste containers are stored in Buildings 7823B, 7823C, 7823D, and 7823E. These buildings are tent-like fabric structures (fire resistant polyvinylchloridecoated polyester) with steel frames resting on gravel pads (Yong May 12, 1998).

\subsubsection{Hanford Inventory}

Hanford has 38 drums (thirty 55 -gal and eight 110 -gal drums) of ${ }^{233} U$ waste. Collectively, these containers comprise $9.6 \mathrm{~m}^{3}$ and $7.3 \mathrm{~kg}$ of ${ }^{233} \mathrm{U}$. Of this inventory, only 2 drums have ${ }^{233} \mathrm{U}$ concentrations that would be considered exception-case material. Hanford's ${ }^{233} U$ waste was generated from the Hanford Purex Plant ${ }^{233}$ U production campaigns in 1966 and 1970. The waste consists of graphite fuel blocks packaged in $17-\mathrm{H}$ drums, which contain concrete shielding. This material is managed as stored contacthandled (CH) TRUW (see Sect. 2.4.2). However, the waste is located in trenches (at the Hanford Retrievable Storage Area 218-W-4B) and, thus, is not easily accessible. The Hanford ${ }^{233} U$ waste does not exceed transuranic (TRU) concentrations of $100 \mathrm{nCi} / \mathrm{g}$ and, thus, is not certified to be shipped to the WIPP. Hanford plans to conduct trench retrieval operations of this material during 2000 to 2012 if federal funding is available (Coony April 3, 1998). 


\subsubsection{LANL Inventory}

LANL has 37 containers of ${ }^{233} \mathrm{U}$ waste without any TRU isotopes. These containers include 10 crates and $27-30$-gal drums that collectively contain $\sim 4.3 \mathrm{~kg}$ of ${ }^{233} \mathrm{U}$. Of this inventory, 9 containers (all 30 -gal drums) have ${ }^{233} \mathrm{U}$ concentrations at levels that would be considered exception-case material. The crates are located in a pit, and the 30-gal drums are stored in a trench. The site currently manages all of the 37 containers as buried CH TRUW. Most of the items stored in the crates include standard equipment for either laboratory analysis or material processing and handling.

\subsection{WASTE INVENTORIES}

\subsubsection{Definitions}

Uranium-233-bearing materials are also found in some TRUW and some LLW. TRUWs have been generated from DOE defense program activities. The TRUW category is specific to DOE; it does not apply to wastes regulated by the U.S. Nuclear Regulatory Commission (NRC). DOE Order 5820.2A, Radioactive Waste Management, defines TRUW as waste that (1) is contaminated with alpha-emitting TRU radionuclides (i.e., those with atomic numbers $>92$ ) with half-lives $>20$ years and (2) contains a total concentration of such radionuclides in excess of $100 \mathrm{nCi} / \mathrm{g}$ of waste at the time of assay (DOE September 26,1988$)$.

DOE Order 5820.2A also states that heads of field elements can determine that other alpha-contaminated waste at the site(s) may be managed as TRUW. Consequently, wastes containing radionuclides such as ${ }^{233} \mathrm{U}$, which do not meet the strict definition of a TRU radionuclide because of their atomic numbers, may be managed as TRUWs at some sites, although it is not by definition TRUW.

For disposal, TRUW containing ${ }^{233} \mathrm{U}$ is acceptable at the WIPP as long as it meets the WIPP waste acceptance criteria (WACs) (DOE Carlsbad Area Office April 1996). For a waste to be certified as TRUW, its TRU content must exceed $100 \mathrm{nCi} / \mathrm{g}$. As long as that requirement is met, other radionuclides such as ${ }^{233} \mathrm{U}$ may be present as co-contaminants. A waste stream with only ${ }^{233} \mathrm{U}$ as a contaminant would not be acceptable for WIPP. As the previously described provision of DOE Order 5820.2A indicates, sites may elect to handle (i.e., treat, transport, and store) wastes contaminated with ${ }^{233} \mathrm{U}$ in the same manner as TRUW based on the potential hazards. However, in accordance with the WIPP Land Withdrawal Act (U.S. Congress 1996) such materials cannot be shipped to WIPP for disposal. 
As defined by the Low-Level Waste Policy Act (Public Law 95-573 December 22, 1980), LLW is radioactive waste not classified as high-level waste (HLW), TRUW, SNF, or by-product material specified as uranium or thorium tailings and waste.

Radioactive wastes may also contain chemically hazardous materials as defined by the Resource Conservation and Recovery Act. If there are such materials in the wastes, there are additional DOE waste management requirements.

\subsubsection{TRUW Inventory}

Table 2.7 lists those sites that potentially have TRUW with concentrations of ${ }^{233} U$. TRUW can be further classified as either as either $\mathrm{CH}$ or remote-handled $(\mathrm{RH})$, depending upon the radiation level at the surface of the waste package (WP) at the time of packaging. If this level is $\geq 200 \mathrm{mrem} / \mathrm{h}$, the WP is classified as RH TRUW. Table 2.8 gives the characteristics of the current inventories of $\mathrm{CH}$ and $\mathrm{RH}$ TRUWs at DOE sites. A breakdown of the uranium isotope content of these wastes is provided in Table 2.9. Tables 2.8 and 2.9 both (Harvill March 2, 1998; and DOE December 1997) include contributions from mixed (hazardous and radioactive) as well as nonmixed (purely radioactive) materials. Some ${ }^{233} \mathrm{U}$ containing wastes also contain ${ }^{239} \mathrm{Pu}$ and are considered TRUW, not ${ }^{233} \mathrm{U}$ wastes.

\subsubsection{Inventory Summary in Waste Drums and Containers}

Figure 2.5 summarizes the quantities of ${ }^{233} U$ in 55 -gal waste drums and containers for the 4 major inventory sites (ORNL, LANL, INEEL, and Hanford) considered in this study. The number of drums at each site is graphically shown for each of the following four categories of ${ }^{233} \mathrm{U}$ mass concentration (expressed as grams per drum):

- 0 to $<4 \mathrm{~g} / \mathrm{drum}$

- $4 \mathrm{~g} / \mathrm{drum}$ to $<50 \mathrm{~g} / \mathrm{drum}$

- $50 \mathrm{~g} / \mathrm{drum}$ to $\leq 200 \mathrm{~g} / \mathrm{drum}$

- $>200 \mathrm{~g} /$ drum

The latter category includes some of the exception-case material currently in storage. 
Table 2.7. List of TRUW storage sites

\begin{tabular}{|c|c|c|}
\hline $\begin{array}{l}\text { Symbol } \\
\text { or label }\end{array}$ & Site & Location \\
\hline ANL-E & Argonne National Laboratory-East & Argonne, Illinois \\
\hline ANL-W & Argonne National Laboratory-West & Idaho Falls, Idaho \\
\hline ARCO & Atlantic Richfield (Medical Products) Company & Reading, Pennsylvania \\
\hline ETEC & Energy Technology Engineering Center & Canoga Park, California \\
\hline Hanford & Hanford Site & Richland, Washington \\
\hline INEEL & Idaho National Engineering and Environmental Laboratory & Idaho Falls, Idaho \\
\hline KAPL & Knolls Atomic Power Laboratory & Schenectady, New York \\
\hline LANL & Los Alamos National Laboratory & Los Alamos, New Mexico \\
\hline LBNL & Lawrence Berkeley National Laboratory & Berkeley, California \\
\hline LLNL & Lawrence Livermore National Laboratory & Livermore, California \\
\hline Mound & Mound Plant & Miamisburg, Ohio \\
\hline MURR & University of Missouri Research Reactor & Columbia, Missouri \\
\hline NTS & Nevada Test Site & Mercury, Nevada \\
\hline ORNL & Oak Ridge National Laboratory & Oak Ridge, Tennessee \\
\hline PGDP & Paducah Gaseous Diffusion Plant & Paducah, Kentucky \\
\hline PANT & Pantex Plant & Amarillo, Texas \\
\hline RFETS & Rocky Flats Environmental Technology Site & Golden, Colorado \\
\hline SNL-NM & Sandia National Laboratory-New Mexico & Albuquerque, New Mexico \\
\hline SRS & Savannah River Site & Aiken, South Carolina \\
\hline TBE & Teledyne Brown Engineering & Westwood, New Jersey \\
\hline USAMC & U.S. Army Material Command & Rock Island, Illinois \\
\hline WVDP & West Valley Demonstration Project & West Valley, New York \\
\hline
\end{tabular}


Table 2.8. Current characteristics of DOE site TRUW (mixed and nonmixed) ${ }^{\mathrm{a}}$

\begin{tabular}{|c|c|c|c|c|c|c|c|}
\hline \multirow[b]{2}{*}{ Site } & \multicolumn{2}{|c|}{$\begin{array}{c}\text { Volume } \\
\left(\mathrm{m}^{3}\right)\end{array}$} & \multirow{2}{*}{$\begin{array}{c}\text { Total waste } \\
\text { mass } \\
(\mathrm{g})\end{array}$} & \multicolumn{4}{|c|}{ Breakdown of mass (g), by fissile nuclide } \\
\hline & As-generated & $\begin{array}{l}\text { Final } \\
\text { form }\end{array}$ & & ${ }^{233} \mathrm{U}$ & ${ }^{235} \mathrm{U}$ & ${ }^{239} \mathrm{Pu}$ & ${ }^{241} \mathbf{P u}$ \\
\hline \multicolumn{8}{|c|}{ Contact-Handled TRUW } \\
\hline INEEL & $64,760.2$ & $35,979.7$ & $45,600,000,000$ & 93,200 & 28,800 & 647,000 & 1,340 \\
\hline ORNL & 921.1 & 460.6 & $235,000,000$ & 10,200 & 2,900 & 15,100 & 444 \\
\hline Others ${ }^{b}$ & $\underline{28.777 .8}$ & $\underline{29,159.8}$ & $17,748,075,000$ & 12,834 & 204.017 & $\underline{4,333,550}$ & 9,546 \\
\hline Totals & $94,459.1$ & $65,600.1$ & $63,583,075,000$ & 116,234 & 235,717 & $4,995,650$ & 11,330 \\
\hline \multicolumn{8}{|c|}{ Remote-Handled TRUW } \\
\hline INEEL & 62.0 & 159.6 & $95,500,000$ & 25 & 2,360 & 498 & 1 \\
\hline ORNL & $1,283.0$ & $1,385.4$ & $1,020,000,000$ & 3,080 & 8,080 & 427 & $<1$ \\
\hline Others $^{c}$ & 811.0 & 808.2 & $402,343.000$ & 47 & $\underline{63,741}$ & $\underline{10.628}$ & 74 \\
\hline Totals & $2,156.0$ & $2,353.2$ & $1,517,843,000$ & 3,152 & 74,181 & 11,553 & 75 \\
\hline
\end{tabular}

${ }^{a}$ Based on Harvill March 2, 1998, and DOE December 1997.

${ }^{b}$ Contributions from 20 sites.

${ }^{c}$ Contributions from 9 sites. 
Table 2.9. Isotopic breakdown of uranium mass (g) in DOE site TRUW

\begin{tabular}{|c|c|c|c|c|c|c|}
\hline Site & ${ }^{232} \mathrm{U}$ & ${ }^{233} \mathrm{U}$ & ${ }^{235} U$ & ${ }^{238} U$ & Other $^{b}$ & Total U \\
\hline \multicolumn{7}{|c|}{ Contact-Handled TRUW } \\
\hline INEEL & 1.13 & 93,200 & 28,800 & 344,000 & 1,106 & 467,107 \\
\hline ORNL & 0.01 & 10,200 & 2,900 & 129,000 & 2,686 & 144,786 \\
\hline Others ${ }^{c}$ & $d$ & 12,834 & $\underline{203,288}$ & $\underline{17,489,918}$ & $\underline{13,382}$ & $\underline{17,719,422}$ \\
\hline Totals & 1.14 & 116,234 & 234,988 & $17,962,918$ & 17,174 & $18,331,315$ \\
\hline \multicolumn{7}{|c|}{ Remote-Handled TRUW } \\
\hline INEEL & & 25 & 2,360 & 4,010 & $<1$ & 6,395 \\
\hline ORNL & 0.10 & 3,080 & 8,080 & $3,100,000$ & 788 & $3,111,948$ \\
\hline Others ${ }^{e}$ & - & 47 & $\underline{63,741}$ & 34,207 & - & 97,995 \\
\hline Totals & 0.10 & 3,152 & 74,181 & $3,138,217$ & 788 & $3,216,338$ \\
\hline
\end{tabular}

aBased on Harvill March 2, 1998, and DOE December 1997.

${ }^{\mathrm{b}}$ Includes contributions (if any) from ${ }^{234} \mathrm{U},{ }^{236} \mathrm{U}$, and ${ }^{237} \mathrm{U}$.

${ }^{c}$ Contributions from 20 sites.

${ }^{\mathrm{d}}$ Trace amount (much less than $1 \mathrm{~g}$ ).

${ }^{\mathrm{e}}$ Contributions from 9 sites. 
ORNL DWG $98-4580$

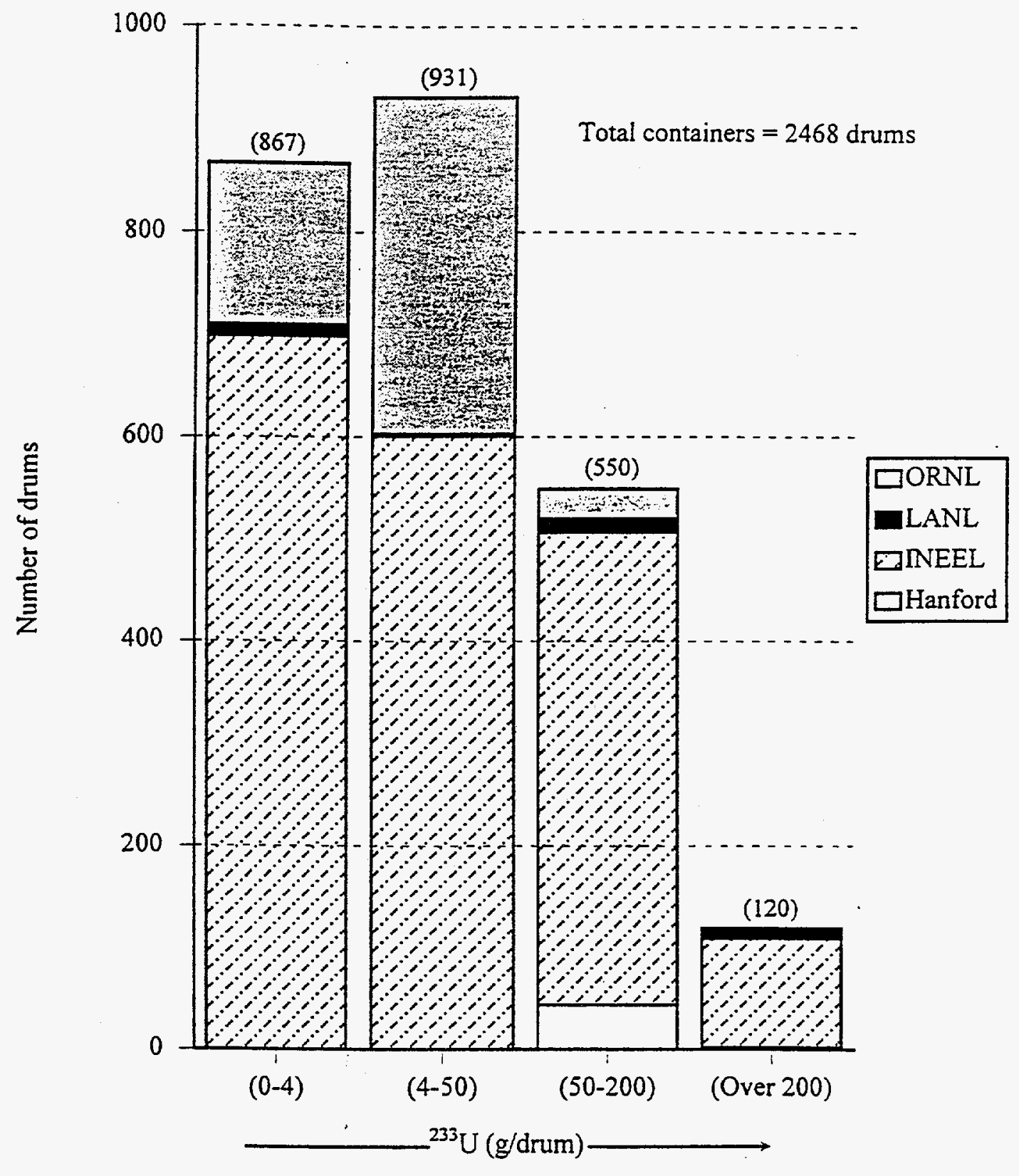

Fig. 2.5. Quantities of ${ }^{233} \mathrm{U}$ in 55-gal (208-L) waste drums and containers. 


\section{DISPOSAL AND DISPOSITION OPTIONS}

\subsection{PATHWAYS FOR DISPOSAL AS A WASTE OR DISPOSITION AS A FISSILE MATERIAL}

The definition of ${ }^{233} \mathrm{U}$ wastes is dependent upon disposal and disposition options. Figure 3.1 shows these options from a top-level perspective.

\subsection{FISSILE MATERIAL DISPOSITION}

The United States, as part of its nuclear-arms-control policies, is proposing that the United States and Russia, in parallel, convert excess weapons-usable material into non-weapons-usable material. The current inventory of ${ }^{233} \mathrm{U}$ is considered weapons-usable material (i.e., it has not been isotopically diluted with ${ }^{238} \mathrm{U}$ ); thus, it is a candidate material to be converted into a non-nuclear-weapons form. DOE's Office of Fissile Materials Disposition is currently evaluating disposition options for excess ${ }^{233} \mathrm{U}$. A recent report (Forsberg January 1998) describes the program and potential disposition options. The basic approach is to convert weapons-usable ${ }^{233} \mathrm{U}$ to a non-weapons-usable material by isotopic dilution with ${ }^{238} \mathrm{U}$ (Sect. 5) to $<12 \mathrm{wt} \%{ }^{233} \mathrm{U}$ in ${ }^{238} \mathrm{U}$.

No decisions have been made on the future use or disposition of weapons-usable ${ }^{233} \mathrm{U}$. The material may be kept in its current form. Alternatively, the ${ }^{233} \mathrm{U}$ may be converted into non-weapons-usable ${ }^{233} \mathrm{U}$ by isotopically diluting it to $<12 \mathrm{wt} \%{ }^{233} \mathrm{U}$ in ${ }^{238} \mathrm{U}$ and kept for future use (research, medical applications, power reactor fuel, etc.). Last, a decision may be made to dispose of the ${ }^{233} \mathrm{U}$ by converting it into a waste form that could be sent to a WIPP- or Yucca Mountain (YM)-type facility.

\subsection{DISPOSAL OPTIONS}

\subsubsection{Requirements for Disposal}

If ${ }^{233}$ U-containing materials are defined as wastes, the preferred disposal option is likely to be a geological repository. The radiological characteristics of ${ }^{233} U$ are similar to TRU elements, such as plutonium. The primary long-term hazard from both is alpha radiation. Current U.S. policy calls for greater confinement disposal (up to and including geological repository disposal) for wastes containing alphaemitting TRU isotopes in concentrations exceeding $100 \mathrm{nCi} / \mathrm{g}$ of waste. Such a policy would generally prohibit shallow-land disposal (SLD) of ${ }^{233} \mathrm{U}$. 


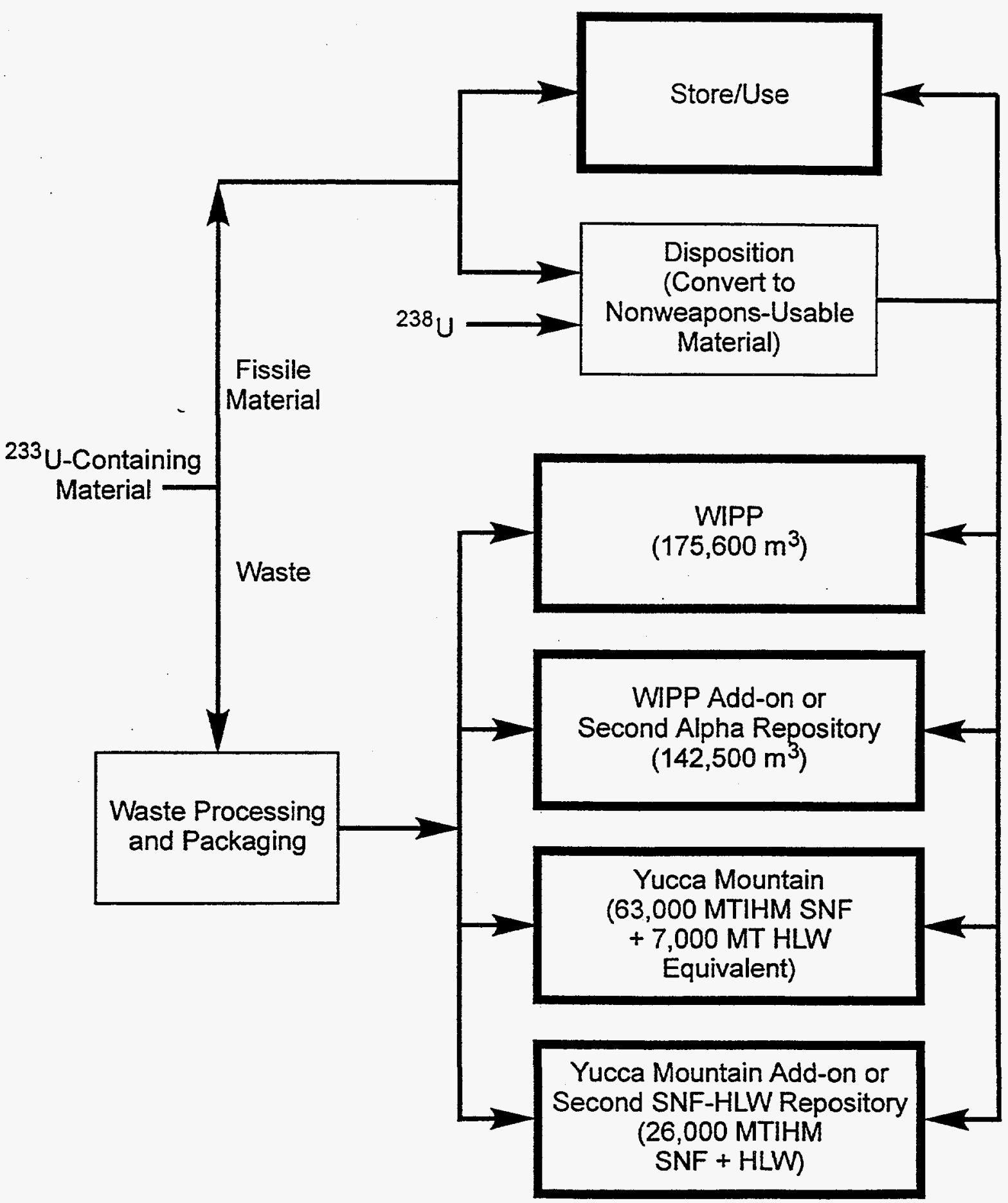

Fig. 3.1. Technical options for management of ${ }^{233}$ U-containing materials. 
The specific activity of ${ }^{233} \mathrm{U}$ is $9.6 \times 10^{6} \mathrm{nCi} / \mathrm{g}$. To dilute pure ${ }^{233} \mathrm{U}$ to alpha-radiation levels allowed in SLD facilities, the ${ }^{233} U$ would have to be diluted by about a factor of 100,000 . Diluting radioactive waste to change its waste classification and allow SLD is usually prohibited unless there are very special conditions. Accomplishment of such a large dilution would not be practicable for shallow-land burial of wastes containing significant quantities of ${ }^{233} \mathrm{U}$.

The United States is developing two geological disposal facilities for wastes: WIPP and the YM repository. The WIPP facility is nearing operation. The YM site is being characterized to determine its suitability for disposal of HLW and SNF. No decision has yet been made on site suitability.

\subsubsection{WIPP}

The WIPP facility is designed for disposal of defense TRUW. Technically, it is designed to isolate alpha wastes from the open environment. TRUW is one type of alpha waste. Plans are for WIPP to become operational in 1998. Because the original facility was designed during the cold war, it was originally expected to receive TRUW with only very low concentrations of plutonium or other actinides. Such wastes primarily consist of contaminated clothing, broken equipment, and decommissioning debris. Any plutoniumcontaining material with significant quantities of plutonium would have been recycled for recovery of the plutonium. Because of the expected low content of plutonium and other fissile materials, TRUW processing facilities, storage facilities, and transportation casks to ship material to WIPP and the WIPP facility were not designed or licensed to handle any form of concentrated fissile material that would require more than standard industrial security. With the end of the cold war, consideration has been given to sending wastes with higher fissile contents to WIPP.

By law (U.S. Government 1996), WIPP is authorized to receive and dispose of $175,600 \mathrm{~m}^{3}$ of TRUW generated from defense operations. DOE, in the environmental impact statement (EIS) for WIPP (September 1997), has determined that another $142,000 \mathrm{~m}^{3}$ of wastes may require disposal by 2033 in a geologic disposal facility such as WIPP. Much of this waste does not yet exist in packaged form; it will be generated as old cold-war facilities are decontaminated and decommissioned. These wastes include added defense TRUW, other government TRUW generated from nondefense activities, and other wastes that may require geological disposal.

The enabling legislation for WIPP (U.S. Government 1996) defines the purpose of WIPP as disposal of defense TRUW. Historically, wastes containing ${ }^{233}$ U have been treated as TRUW (i.e., treated similarly to wastes containing plutonium) because the primary hazard-alpha radiation-is identical in both waste types and, thus, the same types of disposal facilities are required. However, ${ }^{233} \mathrm{U}$ is not defined as a TRU 
radionuclide, and, thus, by law, wastes containing only ${ }^{233} \mathrm{U}$ can not be sent to WIPP. Defense-generated TRUW that contains plutonium and ${ }^{233} U$ can be sent to WIPP. Furthermore, some of the ${ }^{233} U$ may or may not be defense-related wastes. Because of the $142,000 \mathrm{~m}^{3}$ of other wastes that ultimately will require disposal, either (1) a second WIPP-type facility must be built, (2) WIPP must be expanded with congressional authorization to accept these other materials, or (3) some new option must be identified. This second waste volume includes an initial estimate of ${ }^{233} \mathrm{U}$-containing waste volumes requiring disposal.

\subsubsection{YM Repository}

The United States is investigating the option of a geological repository for SNF and HLW at YM in southern Nevada. By law, it is designed to accept 63,000 metric tons initial heavy metal (MTIHM) of commercial light-water reactor SNF and the equivalent of 7000 MTIHM of solidified HLW. The SNF contains large quantities of fissile material, but none of this is in a form that is easy to recover for construction of nuclear weapons. It is estimated (DOE December 1997) that an additional 26,000 MTIHM SNF will ultimately have to be disposed of in addition to additional HLW. This will require the building of a second SNF-HLW repository or adding to the proposed YM repository.

The waste acceptance criteria (WACs) for the proposed YM repository are substantially different than those for WIPP. YM is being designed primarily for SNF. Because significant decay heat is generated by SNF, the repository is being designed to withstand significant heat generation and operate at elevated temperatures. This and other constraints require that all wastes be packaged in high-integrity containers. Partly as a consequence of these constraints, the proposed repository will not accept combustible wastes, wastes containing chelating agents, or wastes containing hazardous chemical agents (hazardous materials, as defined by the Resource Conservation and Recovery Act).

The proposed YM repository could receive wastes containing ${ }^{233} \mathrm{U}$ as defined in this document. There are two constraints:

- Available space. There is a legal limit on the quantity of waste that this repository is allowed to receive. There is insufficient space in the authorized capacity for $\mathrm{YM}$ for ${ }^{233} \mathrm{U}$ wastes. If the law were changed or a second such repository were built, a YM-type facility would become an acceptable disposal facility for ${ }^{233} \mathrm{U}$ wastes.

- Waste form. Major processing of ${ }^{233} U$ wastes would be required for the wastes to be accepted. This would include destruction of all organics and elimination of hazardous materials. Any waste form for a YM-type facility requires an extensive waste form characterization and certification process. 


\subsection{EXCEPTION-CASE MATERIAL}

The exception-case material is primarily a mixture of ${ }^{233} \mathrm{UO}_{2}$ and $\mathrm{ThO}_{2}$. If disposal is desired, the chemical and radiological characteristics may allow this material to go to a WIPP-or YM-type facility. Unlike the ${ }^{233} U$ wastes as defined in this report, exception-case material is much better characterized and understood. The same legal and capacity constraints that exist for ${ }^{233} \mathrm{U}$ wastes apply to this material if it is to be disposed of as a waste.

\subsection{CONCLUSIONS}

The physical, chemical, and radiological characteristics of existing ${ }^{233} \mathrm{U}$ wastes are similar to those of TRUW. From an engineering, a cost, and a safety perspective, wastes containing significant concentrations of ${ }^{233} \mathrm{U}$ should be managed in a similar manner as TRUW. The requirements for safe management are essentially identical. The enabling legislation for the WIPP facility prohibits their disposal in WIPP. For waste management purposes, ${ }^{233} \mathrm{U}$ wastes should continue to be managed like TRUW and steps should be taken when disposal decisions are made on future TRUW and other wastes that can not go to WIPP to ensure the inclusion of this waste.

There is one caveat to this recommendation. If waste treatment processes are developed that allow the waste to be converted to a waste form that meets YM-type requirements, serious consideration should be given to processing the wastes. Given the uncertainties associated with disposal of ${ }^{233} U$-containing wastes, it would be desirable to convert the wastes into a form that would be acceptable by any geological repository.

The physical and chemical properties of most of the exception-case material indicate that if it to be disposed of, there are no strong technical reasons to chose one repository type over the other type. Most of the material could be processed and packaged into a form acceptable to any repository. 



\section{NUCLEAR CRITICALITY ISSUES IN DISPOSAL}

\subsection{INTRODUCTION}

One unique characteristic of fissile-bearing wastes - when they are compared to other radioactive wastes-is the potential of the former for nuclear criticality, if sufficient amounts and concentrations of fissionable materials exist with appropriate geometry. The required amounts and concentrations depend upon the types of fissionable materials, availability of moderators, and concentrations of neutron absorbers. This potential for criticality creates unique waste management issues. The criticality control strategies-both technical and institutional-are still being developed for SNF and other fissile wastes requiring geological disposal. The technical and institutional issues associated with ${ }^{233} \mathrm{U}$ are discussed, and recommendations are based on what is currently known.

\subsection{TECHNICAL AND ENVIRONMENTAL ISSUES}

The purpose of a geological repository is to isolate radionuclides in waste from the public and the environment until the highly radioactive materials have decayed to stable, nonradioactive elements, after which time the risk from the wastes is then low. For actinides such as ${ }^{233} \mathrm{U}$, the time period for significant radionuclides to decay may be measured in hundreds of thousands of years. Uranium-233 has a half-life of $\sim 160,000$ years. The chosen method of isolation of such radioactive materials is burial deep underground in rock structures that have been stable and are expected to remain stable for many millions of years.

Nuclear criticality in a disposal site can degrade a site's capabilities to isolate radioactive wastes from society. Consequently, it is important to assure that either nuclear criticality does not occur or that, if it does occur, the radioactive materials are isolated from society. The technical issues associated with nuclear criticality in a repository are described herein as are options to prevent nuclear criticality in a disposal site.

\subsubsection{Criticality Issues}

Naturally occurring nuclear reactors in the geological past (Cowan 1976; IAEA 1975; IAEA 1977; Smellie 1995) indicate that such events generate added radioactivity and heat over hundreds of thousands of years. The heat causes higher temperatures that, in turn, (1) accelerate chemical reactions, which then accelerate the degradation of WPs and other man-made barriers to radionuclide release; (2) cause water movement that may transport radioactivity to the open environment (Buscheck and Nitao 1993); and (3) create uncertainties in disposal facility performance [U.S. Nuclear Waste Technical Review Board (NWTRB) 1996]. Heat can accelerate water movement in both unsaturated (Buscheck, Nitao, and Wilder 1993) and saturated geological environments. Because heat is a driver for groundwater movement, it is also a driver for radionuclide transport. 
Nuclear criticality produces fission products and actinides that must be isolated from the environment. Criticality can increase the long-term hazards of the waste. Disposal sites are designed to contain radionuclides; however, criticality, if it should occur, would occur after the failure of the WP and other engineered barriers. At such a time there may be significant degradation of the site capabilities for radionuclide containment. If the fissionable materials are transported beyond the facility boundaries, nuclear criticality may occur beyond the specific geology chosen to contain the radionuclides.

\subsubsection{Uranium Geochemistry}

Uranium (of any isotopic makeup) in any disposal site may ultimately dissolve into the groundwater, be transported, and reprecipitate. The specifics depend upon the local geochemistry and geological evolution over time. The same processes that have created uranium ore bodies over the last several billion years of the evolution of the earth still operate on uranium within and beyond a disposal site. Nuclear criticality may occur if these geochemical processes concentrate the fissile uranium and the other fissionable materials.

The general geochemistry of earth is well known. The planet exists under chemically reducing conditions and initially had a chemically reducing atmosphere (Harper and Jacobsen 1996). With the evolution of life and photosynthesis, the atmosphere was converted from a reducing atmosphere to an oxidizing atmosphere about two billion years ago (Cloud 1988). On land, the oxidizing conditions extend from the atmosphere to below the earth's surface for distances measured from $<1 \mathrm{~cm}$ (coal deposits, swamps, etc.) to $>1000 \mathrm{~m}$. The ocean is oxidizing, but sludges on the bottom are, for the most part, under chemically reducing conditions because of the decomposition of organic material.

The solubility of uranium compounds is strongly dependent upon the oxidation conditions of the environment. Under geochemical reducing conditions, uranium is in the +4 valence state, is highly insoluble in water $(<1 \mathrm{ppb})$, and is often found as uranium dioxide $\left(\mathrm{UO}_{2}\right)$. Under chemically oxidizing conditions, uranium is in the +6 valence state, is 2 to 4 orders of magnitude more soluble than under reducing conditions, and is often found as a uranyl $\left(\mathrm{UO}_{2}{ }^{+2}\right)$ ion. Oxygen dissolved in water will oxidize uranium from the +4 to the +6 valence state. Because of these chemical characteristics (Cowan 1976; Deffeyes and MacGregor 1980; Wronkiewicz et al. 1992; Orlander 1996; Smith, Freeborn, and Scheetz 1983; and Brookins 1984), many uranium ore deposits are formed by (1) oxidation of uranium from the +4 to the +6 valence state by oxidizing groundwater (from rain), (2) subsequent dissolution in groundwater, (3) transport in groundwater, and (4) reprecipitation when the groundwater flows through a chemically reducing environment, which reduces uranium from the +6 back to the +4 valence state (Fig 4.1 ). Chemically reducing environments (Sylvester, Campbell, and Bowyer 1997; Smith, Freeborn, and Scheetz 1983; Brookins 1984; Smith, Scheetz, Anderson, and Smith 1982) are primarily, but not exclusively, created by organic materials and iron in the +2 and metal state. 

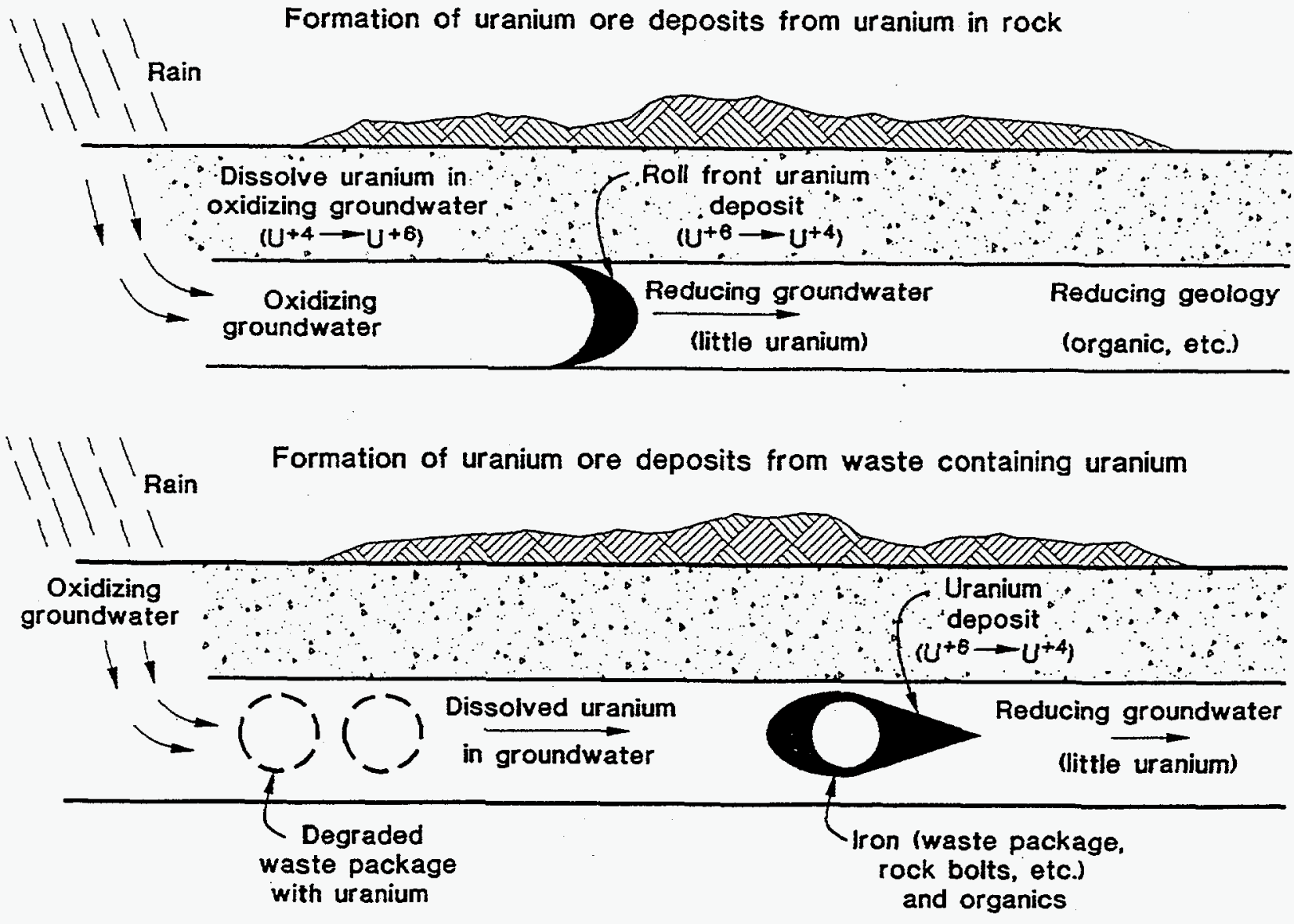

Fig. 4.1. Natural and man-made formation of uranium ore deposits. 
This relatively unusual redox chemistry implies that, unlike most other types of ore deposits, many uranium ore deposits migrate over time (Deffeyes and MacGregor 1980). Flowing oxidizing groundwater will also oxidize other reducing agents within rock. Uranium precipitated by chemical reduction will then be reoxidized, dissolved, transported, and reprecipitated. The uranium remains at the boundary between chemically oxidizing and reducing rock conditions and moves as oxidizing groundwater alters the location of this chemical interface. Such uranium ore deposits are known as "roll-front" deposits, and some of these deposits have moved many kilometers over long time periods.

These mechanisms have extracted uranium from rock at concentrations of a few ppm and created ore bodies with uranium concentrations of several tens of percent by weight. The concentration process separates uranium from most other elements, including boron, cadmium, and rare earths. The only elements consistently found with natural uranium ore bodies are silicon, oxygen, and hydrogen in the chemical forms of silica, silicates, and water. Several other biological and physical mechanisms also concentrate uranium over long time periods.

\subsubsection{Fate of Fissile Uranium in a Disposal Site}

Disposal-site uranium has the same geochemistry as natural uranium and behaves in the same manner in the natural environment. For fissile uranium in a disposal facility, there are three possible futures over geological time:

- Fission. The planet has a chemically oxidizing atmosphere and at its depth a chemically reducing geology. The earth's geochemistry creates conditions for a dissolution of uranium in oxidizing groundwater at disposal sites, transport of the uranium in groundwater, and precipitation (concentration) of that uranium when chemically reducing conditions are encountered. Most SLD facilities and some proposed repositories (e.g., YM) have chemically oxidizing conditions. Many other sites will ultimately have oxidizing conditions caused by flow of oxidizing groundwater. Many WP systems contain iron-based alloys or carbon-containing compounds that provide man-made reducing agents within the disposal facility. With oxidizing groundwater, the same geological processes will occur within the WP and the facility with cycles of uranium oxidation, dissolution, transport, and precipitation. After WP failure, the geometry and concentration of the uranium within the WP, within the disposal facility, and beyond the boundary of the facility will continuously change over time. This can lead to conditions that allow nuclear criticality, as has occurred in natural uranium ore deposits in the past.

- Isotopic dilution with natural uranium. In time, dissolved uranium in groundwater with fissionable concentrations different from those of natural uranium will isotopically exchange with natural uranium in the rock and be isotopically diluted to $\sim 0.7 \mathrm{wt} \%{ }^{235} \mathrm{U}$ and trace quantities of ${ }^{233} \mathrm{U}$ if the fissile uranium contains ${ }^{233} \mathrm{U}$. This process eliminates the potential for nuclear criticality. 
- Radioactive decay. Uranium-233 decays to nonfissile isotopes. Its half-life is 160,000 years. Radioactive decay eliminates the potential for nuclear criticality.

Determination of the fate of fissile uranium for a specific disposal site depends upon (1) the total fissionable material inventory at the disposal site, (2) the fissile concentration of the uranium, (3) the climate of the disposal site and its variation with time, (4) the design of the waste facility, (5) the local geology, and (6) the geochcmical evolution of the disposal facility and local geology (uplift, erosion, etc.) over time.

\subsubsection{Criticality Control Strategies}

Nuclear criticality should be avoided in a waste disposal facility to minimize its effect on facility performance in isolating radioactive wastes. However, there are alternative criticality control strategies.

- Predict future evolution of the disposal site. Current efforts are underway to model the long-term behavior of disposal sites. This modeling includes migration of fissile uranium to determine the probability and consequences of nuclear criticality associated with a disposal site. If the estimated risk from nuclear criticality is judged to be unacceptable, the repository design can be changed until the risks are acceptable.

- $A d d D U$. DU can be added to the ${ }^{233} \mathrm{U}$ in the waste until nuclear criticality is not credible. Having the same chemistry as fissionable uranium, DU is the only neutron absorber that cannot separate from fissionable uranium isotopes via operating geochemical processes over geological time.

For ${ }^{233} \mathrm{U}$ criticality control, isotopic dilution with ${ }^{238} \mathrm{U}$ is a preferred technical strategy based on several considerations.

- Cost. The two major fissile uranium isotopes are ${ }^{233} \mathrm{U}$ and ${ }^{235} \mathrm{U}$. The minimum critical mass (CM) of ${ }^{233} \mathrm{U}(\sim 500 \mathrm{~g})$ is significantly smaller than that of ${ }^{235} \mathrm{U}(\sim 700 \mathrm{~g})$. If ${ }^{233} \mathrm{U}$ is not isotopically diluted with DU, there is the potential of the ${ }^{233} U$ controlling the disposal site criticality analysis and criticality licensing requirements. The quantities of ${ }^{233} \mathrm{U}$ wastes are very small compared to other fissile material wastes. There are potentially large cost impacts if a minor isotope controls a disposal facility design and licensing case.

If the waste is being processed, isotopic dilution often minimizes waste volumes. Certain criticality control strategies can increase waste volumes. This is not an issue for wastes as defined herein but is a consideration if it is decided to dispose of exception-case materials. Consider an extreme case. For $1 \mathrm{~kg}$ of ${ }^{233} \mathrm{U}$, the minimum waste volume is $-0.02 \mathrm{~m}^{3}\left(10 \mathrm{~g} \mathrm{U} / \mathrm{cm}^{3}\right)$ if criticality control is by isotopic dilution with DU vs $\sim 1 \mathrm{~m}^{3}$ if criticality control is by concentration limits using the WIPP criticality control strategy.

WIPP prevents nuclear criticality by placing concentration limits on fissile materials in the wastes. That limit is 200 plutonium-equivalent grams per 55 -gal drum. In the WIPP approach to criticality control, the same rules apply to ${ }^{233} \mathrm{U}$; i.e., the ${ }^{233} \mathrm{U}$ limit is $200 \mathrm{~g}^{233} \mathrm{U} / 55$-gal drum. The goal is to minimize risks during processing, storage, and transport operations. As a consequence, this limit would likely apply to any WIPP-type repository and most other waste management operations. If there is a kilogram of ${ }^{233} \mathrm{U}$ in a small volume of waste, the waste must be divided among 5 drums so no drum contains $>200 \mathrm{~g}^{233} \mathrm{U}$. 
The addition of DU to fissile uranium waste and using isotopic dilution (rather than concentration limits) as the criticality control strategy may result in the counter-intuitive result of minimizing waste volumes. If there is $1 \mathrm{~kg}$ of ${ }^{233} \mathrm{U}$ in a small volume of waste, criticality control may be ensured by adding $200 \mathrm{~kg}$ of DU (see following). If DU dioxide is used (with a density that exceeds $10 \mathrm{~g} / \mathrm{cm}^{3}$ ), the volume of DU that must be added is $\sim 0.02 \mathrm{~m}^{3}$. This volume easily fits into a single drum.

- Precedent. An analysis (DOE June 1996) for disposition of surplus HEU (that is declared as waste) concluded that the uranium enrichment should be reduced for long-term criticality control. Using isotopic dilution for ${ }^{233} \mathrm{U}$ criticality control is consistent with earlier decisions on disposal of ${ }^{23} \mathrm{U}$ containing wastes.

- Acceptance within the technical community. The NWTRB (1996)-the congressionally-mandated technical review board for the YM project-analyzed long-term repository criticality issues associated with the proposed YM repository and recommended the consideration of the use of DU for control of nuclear criticality in such facilities.

\subsubsection{Allowable ${ }^{233} \mathrm{U}$ Concentrations in Wastes}

If isotopic dilution (addition of ${ }^{238} \mathrm{U}$ ) is to be used to minimize the potential for nuclear criticality, the technical question is: How much DU is required? Repository studies on ${ }^{233} \mathrm{U}$ have not been performed; however, many studies on nuclear criticality have been done with ${ }^{235} \mathrm{U}$. Using that information, nuclear criticality calculations (Elam 1997; Appendix B of this report) were then completed to determine what isotopic dilutions of ${ }^{233} \mathrm{U}$ with ${ }^{238} \mathrm{U}$ correspond to different ${ }^{235} \mathrm{U}$ enrichments. This determination allows data on waste systems containing ${ }^{235} \mathrm{U}$ to be converted into data applicable to ${ }^{233} \mathrm{U}$ wastes. There is both direct and indirect geological data on nuclear criticality in the natural environment:

- History. The historical geological record (Cowan 1976; Smellie 1995; Brookins 1984 and 1990; Von Marvic 1993) shows that nuclear criticality has occurred in natural uranium ore bodies. For example, 16 natural nuclear reactors have been identified at Oklo, Gabon, Africa. The nuclear chain reactions began when the ${ }^{235} \mathrm{U}$ enrichment of natural uranium was about $3.6 \mathrm{wt} \%$. After operation and the ensuing generation of heat and fission products, ${ }^{235} \mathrm{U}$ enrichments of the uranium were as low as $1.3 \mathrm{wt} \%$ - equivalent to $0.74 \mathrm{wt} \%{ }^{233} \mathrm{U}$ in DU with a ${ }^{235} \mathrm{U}$ content of $0.2 \mathrm{wt} \%$

(Appendix B). Today, natural uranium deposits have a ${ }^{235} \mathrm{U}$ enrichment level of $0.71 \mathrm{wt} \%$ because of the long-term decay of ${ }^{235} \mathrm{U}$. Nuclear criticality can no longer occur in natural uranium ore bodies under geological conditions because of these low enrichment levels (Fig. 4.2).

- Geochemical modeling of uranium ore deposits. The Commissariat a L'Energie Atomique (French Atomic Energy Commission) has studied the conditions during which natural nuclear reactors (ore deposits) form during the concentrating of uranium from rock (Naudet 1978). The analysis indicates that nuclear criticality may occur at enrichments as low as $1.28 \mathrm{wt} \%{ }^{235} \mathrm{U}$ with criticality becoming reasonably probable in some geological environments as enrichments approach $1.64 \mathrm{wt} \%{ }^{235} \mathrm{U}$. Others have estimated that criticality may occur in natural environments with enrichments approaching only $1 \mathrm{wt} \%{ }^{235} \mathrm{U}$ (Cowan 1976)-equivalent to $0.66 \mathrm{wt} \%{ }^{233} \mathrm{U}$ in ${ }^{238} \mathrm{U}$ or $0.53 \mathrm{wt} \%$ ${ }^{233} \mathrm{U}$ in DU with a ${ }^{235} \mathrm{U}$ content of $0.2 \mathrm{wt} \%$ (Elam 1997). 


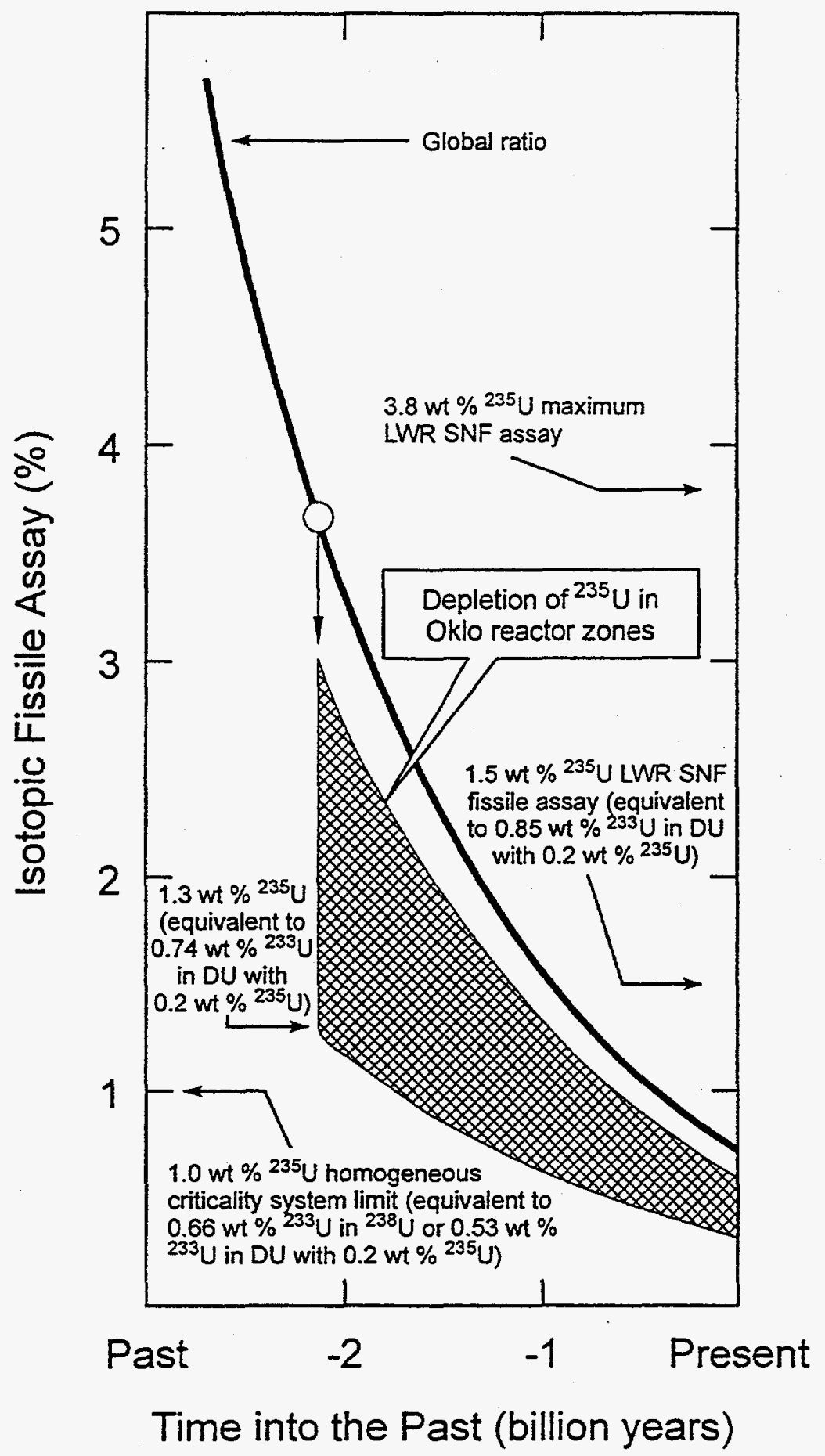

Fig. 4.2. Natural uranium enrichment levels occurring over geological time. 
- Geochemical modeling of low-level radioactive disposal sites. The NRC (June 1997) has modelled SLD sites to determine the potential for nuclear criticality. The analysis indicates a potential for nuclear criticality because of geochemical concentration processes unless the fissile content in the waste is severely restricted or the fissile uranium is isotopically diluted with DU.

Nuclear criticality assessments have been conducted for a variety of other applications. A summary of results is provided herein:

- Engineering experiments and analysis. Criticality calculations (American National Standards Institute, Inc. 1983) and laboratory experiments (Paxton and Pruvost 1987) with the types of materials found in the natural environment indicate that nuclear criticality could, in theory, occur with fissile enrichment concentrations as low as $\sim 1 \mathrm{wt} \%{ }^{235} \mathrm{U}$-equivalent to $0.66 \mathrm{wt} \%{ }^{233} \mathrm{U}$ in ${ }^{238} \mathrm{U}$ or $0.53 \mathrm{wt} \%{ }^{233} \mathrm{U}$ in DU with a ${ }^{235} \mathrm{U}$ content of $0.2 \mathrm{wt} \%$ (Elam 1997), but there is no experimental evidence that this has occurred in nature.

- Environmental analysis. An analysis (DOE June 1996) for disposition of surplus HEU (that is declared as waste) concluded that the uranium enrichment may be reduced to as low as $0.9 \mathrm{wt} \%$ ${ }^{235} \mathrm{U}$ for long-term criticality control. This is a conservative number chosen to bound environmental impacts of process operations to dilute enriched uranium with DU.

- Waste facility safety assessments. Waste process equipment, waste tanks, LLW disposal sites, and other waste management facilities contain wastes with small quantities of enriched uranium. In many facilities, it is not practicable to control the system geometry, the chemistry, or the presence of neutron absorbers. Selective precipitation of uranium into significant deposits is possible. Based on analysis and experiments, many sites require isotopic dilution of ${ }^{235} U$ with ${ }^{238} U$ to ensure that nuclear criticality does not occur. For example, ORNL (Lockheed Martin Energy Systems, Inc. February 1996) requires that any uranium sent to the liquid process waste system contain at least 100 parts ${ }^{238}$ U per part ${ }^{235} \mathrm{U}$.

- Industrial facility assessments. Nuclear criticality safety assessments for industrial facilities (Lewis 1997) indicate that criticality is not a concern if the ${ }^{235} \mathrm{U}$ assay is below $1 \mathrm{wt} \%{ }^{235} \mathrm{U}$ in ${ }^{238} \mathrm{U}$.

The previous data suggest that a reasonable strategy to prevent nuclear criticality in disposal facilities is to require sufficient DU fill in each WP such that the ratio of ${ }^{235} \mathrm{U}$ to ${ }^{238} \mathrm{U}$ is $<1$ wt $\%{ }^{235} \mathrm{U}$ equivalent. The $1 \mathrm{wt} \%$ is also the homogeneous criticality limit for ${ }^{235} \mathrm{U}$ in an optimized system containing water and silicon oxide. Such a limit can be extended to any other fissionable material by determining the corresponding homogeneous criticality limit for that specific isotope in a system containing the isotope, water, and silicon oxide. This has been done for ${ }^{233} \mathrm{U}$ with the result that $1 \mathrm{wt} \%{ }^{235} \mathrm{U}$ in ${ }^{238} \mathrm{U}$ is equivalent to $0.66 \mathrm{wt} \%{ }^{233} \mathrm{U}$ in ${ }^{238} \mathrm{U}$ or $0.53 \mathrm{wt} \%{ }^{233} \mathrm{U}$ in DU with a ${ }^{235} \mathrm{U}$ content of $0.2 \mathrm{wt} \%$ (Elam 1997).

The waste-management subcriticality equivalence calculations between ${ }^{233} \mathrm{U}$ and ${ }^{235} \mathrm{U}$ used the following methodology (Elam 1997). The water-moderated homogeneous infinite media multiplication constant, $k_{\text {inf }}$ for $1 \mathrm{wt} \%{ }^{235} \mathrm{U}$ in uranium was selected as the maximum, yet subcritical, enrichment as the reference value 
for dilution of ${ }^{233} \mathrm{U}$ with $\mathrm{DU}\left(\sim 0.2 \mathrm{wt} \%{ }^{235} \mathrm{U}\right.$ in uranium) to assure subcriticality. Compounds of uranium, enriched to no more than $1 \mathrm{wt} \%{ }^{235} \mathrm{U}$, have been computationally and experimentally demonstrated to remain subcritical in homogeneous water mixtures that are computationally and experimentally equivalent to infinite systems. The maximum multiplication constant $\left(\mathrm{k}_{\text {inf }}\right)$ for an optimized, infinite, homogeneous system containing ${ }^{235} \mathrm{U},{ }^{238} \mathrm{U}$, water, and silicon dioxide was determined; that is, the concentrations of water and silicon dioxide were varied to find the maximum value of $k_{\text {inf }}$. Parametric calculations were then performed to determine the maximum ${ }^{233} \mathrm{U} w \mathrm{w} \%$ in a second infinite, homogeneous system containing ${ }^{233} \mathrm{U}$, DU, water, and silicon dioxide that would have a $\mathrm{k}_{\mathrm{eff}}$ value that was $95 \%$ of the $\mathrm{k}_{\mathrm{inf}}$ of the initial ${ }^{235} \mathrm{U}$ systems. The use of a $k_{\text {inf }}$ for the ${ }^{233} U$ that was $95 \%$ of the value of the $k_{\text {eff }}$ of the ${ }^{235} U$ system provided a conservative calculation that addresses uncertainties for homogeneous mixtures of ${ }^{233} \mathrm{U},{ }^{235} \mathrm{U},{ }^{238} \mathrm{U}, \mathrm{SiO}_{2}$, and $\mathrm{H}_{2} \mathrm{O}$ for which the neutron fission chain reactions are predominantly maintained by thermal neutrons. The optimum ${ }^{233} \mathrm{U}$ system and optimum ${ }^{235} \mathrm{U}$ system had different ratios of $\mathrm{DU}$ to water and $\mathrm{SiO}_{2}$. The calculations determined the effective neutronic equivalency of the ${ }^{233} U$ and ${ }^{235} U$ in repository systems where each system is in its neutronically most reactive homogeneous configuration.

\subsubsection{Whole-Repository Issues}

The potential for nuclear criticality from a disposal site is dependent upon multiple factors including: (1) the total disposal facility inventory of fissile material, (2) the quantity of fissile uranium (plutonium and some other fissile materials are not expected to be mobile in most geological environments), and (3) the uranium enrichment within the disposal facility. For any disposal site, ${ }^{233} U$ is only one of several contributors.

In this context it is noted that over long time periods, most other fissionable materials decay to uranium isotopes. Consequently, these other isotopes will add to the fissile uranium inventory in the disposal site including added ${ }^{233} \mathrm{U}$. The fissionable isotopes of potential concern are shown in Fig. 4.3. This figure [American Nuclear Society (ANS) 1981; General Electric 1996; Clayton 1973; ORNL February 1994] shows all known fissionable isotopes with half-lives in excess of one year, the subcritical-mass limit (SCML), the half-life, and the major radioactive decay modes. The higher actinides with short half-lives, such as isotopes of einsteinium and fermium, are not shown and are not of concern in the context of long-term repository criticality issues because they decay to lower actinides before failure of the WP in a repository. Short-lived isotopes may be a criticality concern during process operations or short-term storage operations. The SCML (ANS 1981) is the mass of the specific isotope "that results in a system known to be subcritical, provided the limiting value of no other controlled parameter of the system is violated." The CM for a specific 
isotope is just above the masses shown in Fig. 4.3. These SCMLs are defined for specific systems such as a metal sphere surrounded with water. For many of these isotopes, smaller CMs exist for exotic systems that contain the specific isotope and exotic materials such as nuclear-grade beryllium. However, such exotic systems could not be credibly created by the earth's geochemistry. For a number of isotopes, it is known that the specific isotope in sufficient quantities would form a $\mathrm{CM}(\mathrm{cm}=y e s)$ but the $\mathrm{CM}$ has not been determined. In other cases, the nuclear data is sufficiently incomplete that it is not known if a critical mass $(\mathrm{cm}=$ questionable $)$ of the specific isotope can be created.

\subsubsection{Implementation of a Criticality Control Strategy Based on DU}

Criticality control for ${ }^{233} \mathrm{U}$-containing wastes can be achieved by mixing ${ }^{233} \mathrm{U}$ to $0.66 \mathrm{wt} \%{ }^{233} \mathrm{U}$ in ${ }^{238} \mathrm{U}$ or to $0.53 \mathrm{wt} \%{ }^{233} \mathrm{U}$ in DU with a ${ }^{235} \mathrm{U}$ content of $0.2 \mathrm{wt} \%$ (Elam 1997). In many cases, long-term criticality control can be accomplished by simple addition of DU to the WP. In some cases, isotopic (chemical) mixing of the ${ }^{233} \mathrm{U}$ and $\mathrm{DU}$ before waste packaging may be required.

Uranium in a WP over time will be found in multiple chemical forms (T. M. Ahn November 1996). The dissolution process for uranium species into groundwater is a multistep process. Fortuitously, the laboratory experiments (W. J. Gray, L. W. Thomas, and R. E. Einziger 1993) indicate that the dissolution rate-limiting step is the same for many different uranium compounds. In such cases (Forsberg May 1998), perfect mixing of ${ }^{233} \mathrm{U}$ with DU and conversion of all uranium to the same chemical form within a single WP is not required for long-term criticality control. DU can simply be added to the WP. The ${ }^{233} U$ and DU will codissolve and isotopically mix in the groundwater.

To use this option, there must be reasonable assurance that criticality will not occur before isotopic mixing of the uranium isotopes in groundwater. In many cases, this condition can be met. For example, if the ${ }^{233} \mathrm{U}$-containing wastes meet the criticality-control requirements for WIPP-type facilities, this method of long-term criticality control is applicable. The operational criticality control strategy for WIPP-type facilities is to limit the fissionable mass in any WP to sufficiently low levels such that the neutron absorbers in the container walls prevent nuclear criticality even if hundreds of containers are packed in arrays. The total fissionable mass per container is substantially below the minimum critical mass. Under these circumstances, fissionable materials from many WPs must be dissolved, transported, and precipitated in a small volume to enable nuclear criticality to occur. The geochemistry required to create a criticality event under these circumstances with pure ${ }^{233} U$ ensures that criticality will not occur if appropriate amounts of DU are in each WP. (There are some chemical species of uranium such as nitrates that dissolve at different rates than metals and oxides. In such cases, the ${ }^{233} U$ and DU may need to be in the same chemical forms or other actions such as use of large excesses of DU may be required.) 
Thorium Series

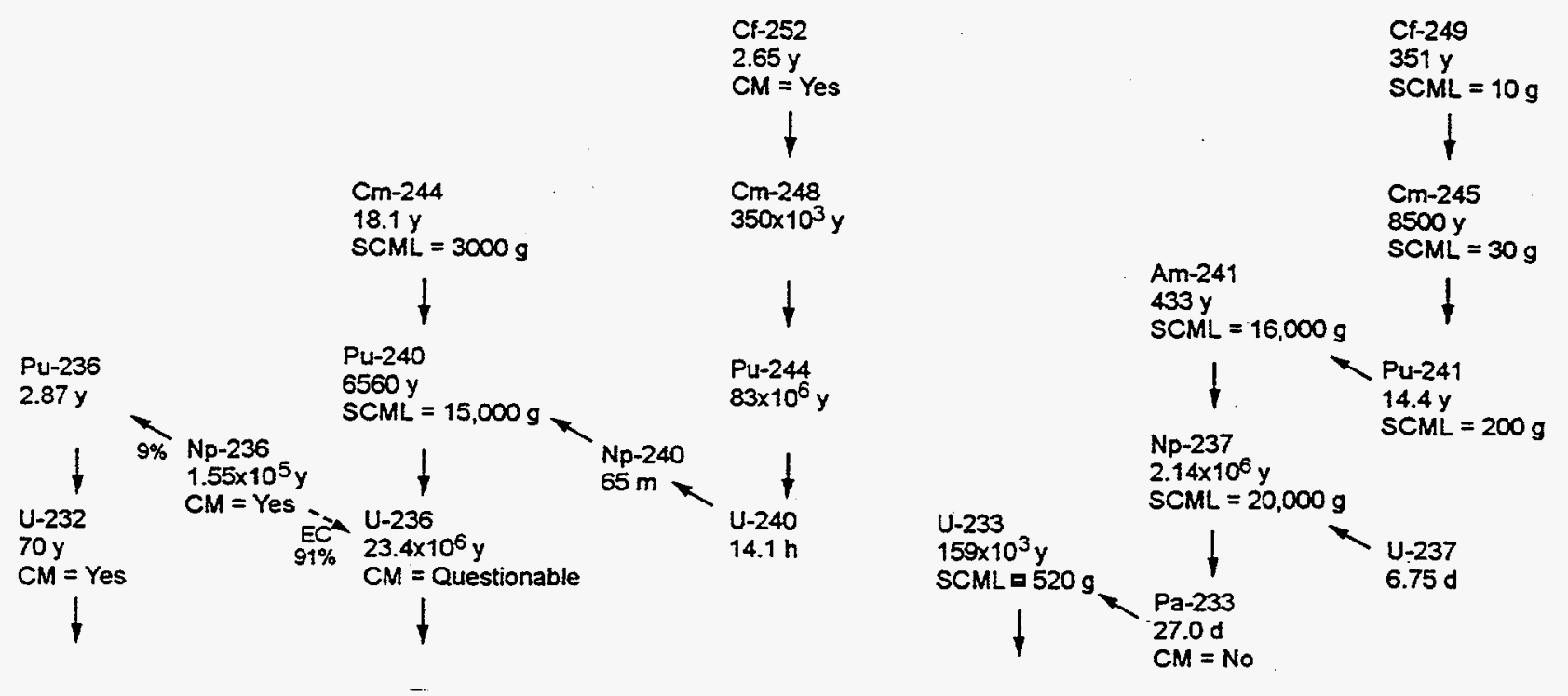

Uranium Series

C -250

$13.1 \mathrm{y}$

Am-242m $\quad C M=$ Yes

$152 \mathrm{y}$

SCML $=13 \mathrm{~g}$

$\mathrm{Cm}-242$

$163 d$

$\uparrow^{1 T}$

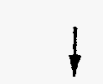

Am-242

$16 \mathrm{~h}$

$C M=$ Yes

Pu-238

$88 y$

SCML $=3000$ $0.0005 \%$

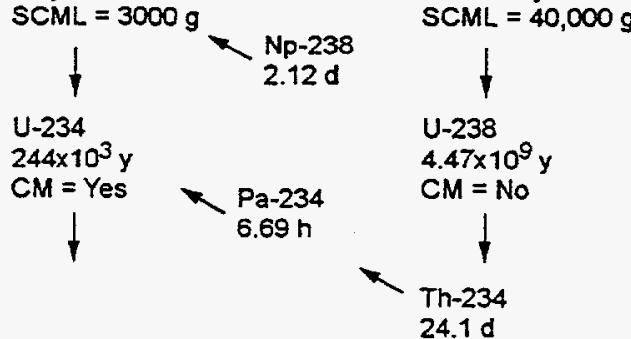

Neptunium Series

Cm-245

8500

Am-241

$433 y$

Np-237

$.14 \times 10^{6}$

Actinium Series

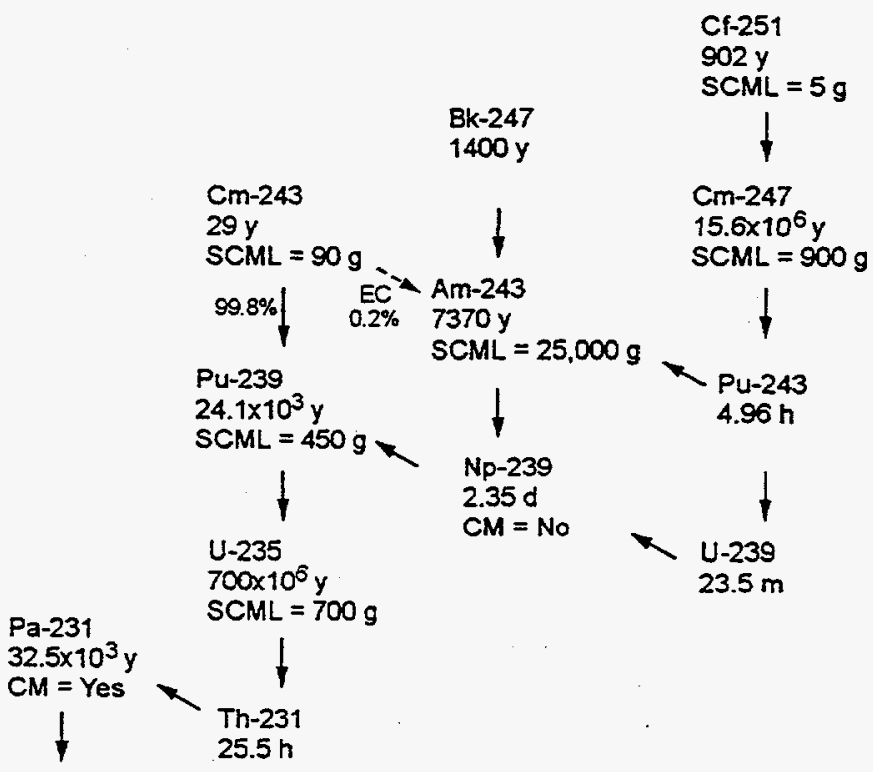

Fig. 4.3. Decay pathways, half-lives, and SCMLs of fissionable isotopes. 
In these cases, there are many operational strategies for isotopic dilution of ${ }^{233} \mathrm{U}$-containing waste with DU. For wastes that are being packaged for disposal, the following approach could be used: Determine from records or measurements the quantity of ${ }^{233} \mathrm{U}$ in the waste and then add $\mathrm{DU}$ in oxide form in paper, cloth, plastic, or metal bags to the WP or waste process as the ${ }^{233} \mathrm{U}$-containing wastes are added. The bag size would be chosen for convenience in handling. DU oxides are preferred because they are relatively chemically stable. The use of prepacked DU oxides avoids potential handling difficulties. The DU oxide bags can be loaded by automated packaging systems that minimize worker exposure. Excess DU is not a concern for this application. Uncertainties in the quantities of ${ }^{233} \mathrm{U}$ can be addressed by addition of more DU. The packaging material for the DU must be compatible with the process. If the only activity is packaging the wastes in drums, the only performance requirement on the bags is that they degrade and fail more rapidly than uranium dissolves in groundwater. Most paper, cloth, plastic, and metal materials meet this requirement. This long-term criticality control strategy that does not require mixing of ${ }^{233} U$ and DU within the WP is only viable if other methods are used to assure operational short-term criticality control.

In a few cases, chemical mixing of the ${ }^{233} \mathrm{U}$ and $\mathrm{DU}$ before packaging may be required to assure longterm criticality control. The historic example is high-temperature, gas-cooled reactor fuel. The fissile uranium is in the form of microspheres clad with carbides and graphite. This cladding material may last for hundreds of millions of years under appropriate conditions (Lotts 1992). Under these very unusual conditions, any DU in the WP may migrate from microspheres before the microspheres fail and the fissile uranium can mix with the DU.

\subsubsection{Availability of DU}

A large excess of DU exists worldwide that far exceeds the potential needs for criticality control. Currently, no substantial use exists for this material. In the United States, about 400,000 t of DU is in storage (Hertzler, Nishimoto, and Otis 1994). DOE is currently looking for uses for this material.

\subsection{REGULATORY REQUIREMENTS}

The regulatory requirements for YM and WIPP are somewhat different and are, therefore, discussed separately. These differences can be attributed to different historical factors and the very-large technical differences related to nuclear criticality between the proposed YM repository and WIPP. Because the proposed YM repository may accept 63,000 MTIHM of SNF, it may contain in excess of $100,000 \mathrm{CMs}$ of fissile material. As such, the issue of long-term criticality in the YM-disposal site is major. The fissile content of WIPP is significantly less. 


\subsubsection{YM}

The regulatory structure for the proposed YM repository (Fig 4.4) is well defined, but there are significant uncertainties about the final performance standards that the repository must meet. Furthermore, there are different technical perspectives on the appropriate criticality control strategies for the repository among various organizations with differing responsibilities for YM. The current status of those activities that impact repository criticality control is described herein.

The regulatory structure for the YM repository is defined by federal law. The U.S. Environmental Protection Agency (EPA) is responsible for issuing general environmental standards for the repository. Standards generally applicable to disposal of HLW, SNF, and TRUW were promulgated in the 1980s; however, because of court challenges and changes in the law, EPA is required to develop new standards. This activity is currently underway. The new standards, by law, must be consistent with the U.S. National Academy of Sciences (NAS) 1995 recommendations on performance standards for the proposed YM repository. NAS recommended that disposal site performance be evaluated out beyond the time of maximum public exposure-this time is after WP failure and within the time frame during which nuclear criticality may impact repository releases of radionuclides. This is a fundamental change. Nuclear criticality occurs only after there is time for package failure and fissile material transport in water. If a repository performance standard is limited in time, there may not be sufficient time for nuclear criticality to occur. In such cases, nuclear criticality is not a major licensing concern.

Based on the EPA standards, the NRC develops regulations that are the bases for licensing the repository for operations. The current regulations will likely be modified to reflect changes in the EPA standard when that standard is completed. The current NRC regulations (1995) require that it be demonstrated by deterministic methods that nuclear criticality will not occur in the repository.

It is proposed by the YM project to use a probabilistic methodology to demonstrate that nuclear criticality will not occur (Scott and Doering 1997). There are two complications to this approach:

- NRC Regulations. The current NRC regulations require that it be demonstrated using a deterministic methodology that nuclear criticality will not occur in the repository. The NRC has the option to change the regulations if it believes that such a change will not reduce public health and safety. The YM project has prepared a technical basis for making such a request (Scott and Doering 1997).

- Technical Feasibility. The NWTRB (1996)-the Congressionally-mandated independent technical review board for the YM project that makes recommendations to Congress and the Secretary of Energy - analyzed long-term repository criticality issues associated with the proposed YM repository and stated: "Although external [to the WP] criticality may be unlikely, it can not be dismissed without thorough analysis. The Board understands that DOE intends to use probabilistic risk analysis methodology to address external criticality. While such an approach is appealing, it may turn out to be costly and time-consuming to the point of impracticality in a repository context because of the very large number of events and geometric configurations possible in a repository...." The board subsequently recommended the consideration of the use of DU for control of nuclear criticality in such facilities. 


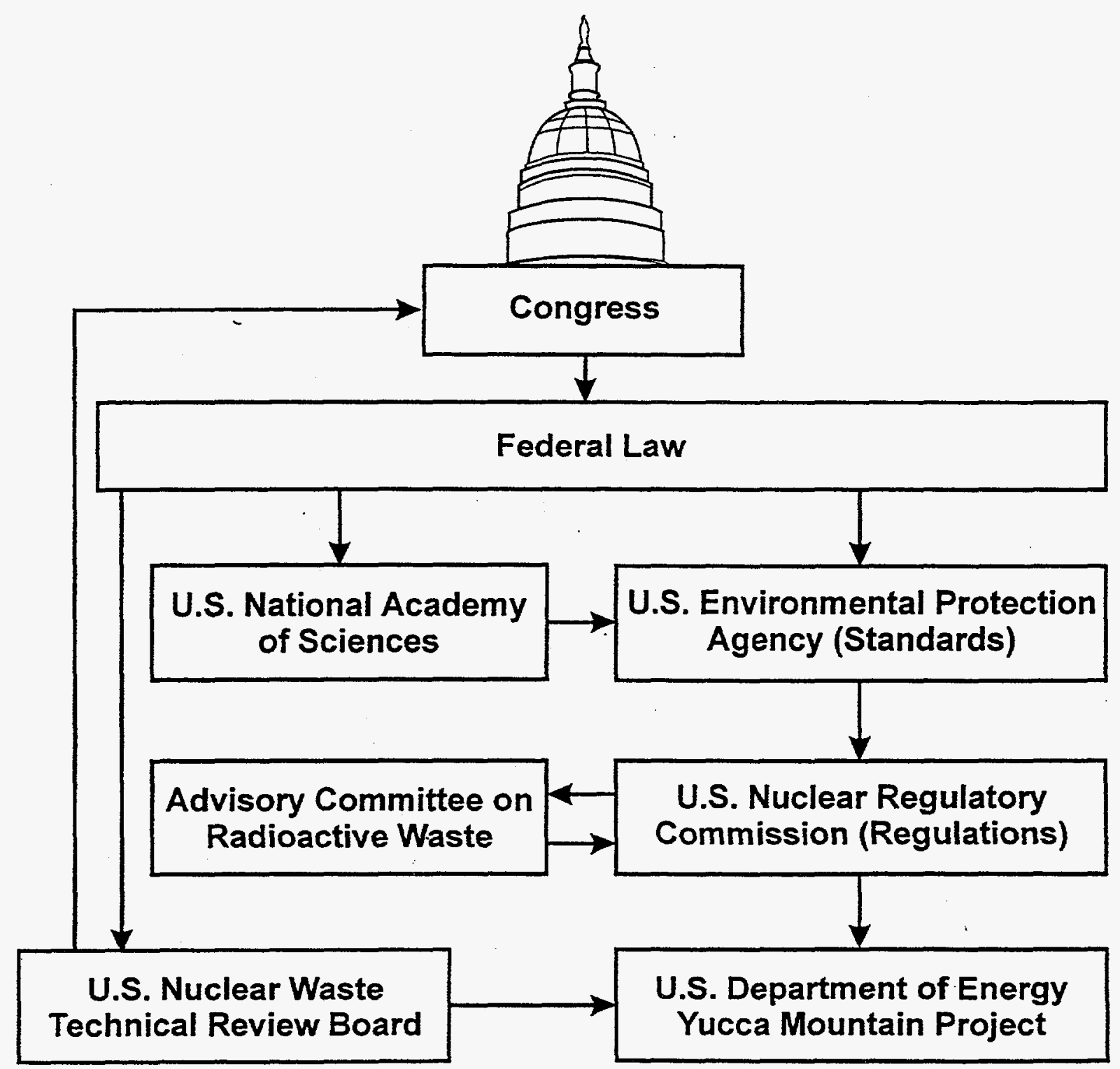

Fig. 4.4. Advisory and regulatory structure for the YM project. 
There are two conclusions that can be drawn from this data: (1) There is regulatory uncertainty, and (2) isotopic dilution to control criticality-a deterministic criticality control strategy-would be acceptable under all of the proposed standards and regulations. These suggest that, if there are not large penalties, isotopic dilution of ${ }^{233} \mathrm{U}$ wastes with $\mathrm{DU}$ is a preferred regulatory strategy.

\subsubsection{WIPP}

The WIPP regulatory structure is substantially different than that of YM. EPA certifies, by rule, compliance with 40 CFR 191, the general environmental standard for HLW, SNF, and TRUW. EPA has recently promulgated a rule certifying such compliance. Different criticality approaches have been adopted for operational and long-term criticality control.

The operational criticality control requirements for WIPP are based on analysis (Boyd and Fecteau 1993; Westinghouse Savannah River Company 1997) and use a deterministic methodology. The results of the analysis (DOE April 1996) was to limit the fissile content of any 55-gal waste drum sent to WIPP to $200 \mathrm{~g}$ equivalent of plutonium or $325 \mathrm{~g}$ equivalent plutonium for a larger $\mathrm{RH}$ waste container. Uranium-233 in this

criticality analysis has the same mass limits per container $\left(200 \mathrm{~g}^{233} \mathrm{U} / 55\right.$-gal drum) as does plutonium. With these limits, WPs can be stacked in any configuration up to three high with minimal risk of criticality occurring.

The long-term criticality control strategy for WIPP (Rechard et al., November 1996; Rechard 1996) is somewhat different than that for YM. This reflects institutional and technical differences between the two repositories. WIPP is certified by EPA (1997) with the requirement to limit total radionuclide releases from WIPP below a defined level for 10,000 years. This can be demonstrated by using a probabilistic approach (Rechard 1997) which considers both the probability of nuclear criticality occurring and the consequences. Both the methodology and time period for compliance are different than for YM. In addition, there are several technical factors that significantly reduce the difficulty in meeting licensing requirements. First, the total fissile inventory in WIPP is much smaller than YM. Second, the WIPP facility is located in salt. Because of the high nuclear cross section of salt, nuclear criticality is unlikely in the repository. For nuclear criticality to occur, the fissile materials must be transported out of the local geological environment.

WIPP, when it opens, will accept TRUW that also contains ${ }^{233} U$. Consequently, the criticality analysis covers ${ }^{233} \mathrm{U}$ in WIPP. However, the assumptions in those analysis assume small total quantities of fissile uranium isotopes going to WIPP. If a decision was made to dispose of exception-case material at WIPP or a future WIPP-type facility, the larger quantities of ${ }^{233} \mathrm{U}$ may require additional analysis. If the ${ }^{233} \mathrm{U}$ is isotopically diluted with DU, it would meet all potential technical and licensing criticality requirements. 


\subsection{OTHER CONSIDERATIONS}

DOE has completed an EIS and issued a record of decision (ROD) for the disposition of excess HEU. The ROD (DOE July 1996) states that, where economically justified, HEU will be converted to LEU to be used as fuel in nuclear power reactors. HEU is converted to LEU by the addition of LEU, natural uranium, or DU. The HEU not suitable for conversion to power reactor fuel (because of other uranium isotopes) is to be blended with DU and disposed of as waste. The final enrichment level is to be below $1 \mathrm{wt} \%$ to minimize the potential for nuclear criticality in disposal facilities.

The decision to use isotopic dilution to eliminate the potential of nuclear criticality from HEU in a disposal facility does not require that the same approach be used to minimize the potential for nuclear criticality for ${ }^{233} U$ wastes. It does, however, establish a precedent.

\subsection{CONCLUSIONS}

\subsubsection{Categorization of ${ }^{233} \mathrm{U}$-Containing Materials}

For a ${ }^{233} \mathrm{U}$-containing material to be classified as a waste as defined in this report, nuclear criticality control must be assured such that ${ }^{233}$ U-containing materials may be managed as any other radioactive waste. It is recommended that two alternative definitions be allowed to define the criticality-control dividing line between waste and exception-case material. $A{ }^{233} \mathrm{U}$-containing material is waste (in terms of criticality control) if it meets WIPP criticality control requirements ( $<200 \mathrm{~g}^{233} \mathrm{U} / 55$-gal drum) or the ${ }^{233} \mathrm{U}$ is isotopically diluted to $<0.66 \mathrm{wt} \%{ }^{233} \mathrm{U}$ in ${ }^{238} \mathrm{U}$. The WIPP criticality control requirement (see Sect. 4.3.2) follows the precedents established for management of plutonium-containing wastes and historical practice for management of ${ }^{233} \mathrm{U}$ wastes. This criticality control requirement is also similar to requirements in other countries (Ogilvie 1997). Any ${ }^{233} U$ containing material with higher concentrations of ${ }^{233} U$ that is to be disposed of will require (unless isotopically diluted with ${ }^{238} \mathrm{U}$ ) some type of exception-case handling to be sent to a WIPP- or YM-type facility. The WIPP criticality limits are general criticality limits that apply to many waste management facilities and would be expected to apply to any future WIPP-type facility. Criticality control limits are also defined for other types of containers with the concentration limits $<1 \mathrm{~kg}^{233} \mathrm{U} / \mathrm{m}^{3}$. 


\subsubsection{Existing Waste Not Requiring Further Processing or Packaging for Other Purposes}

No action is recommended for existing ${ }^{233} \mathrm{U}$ wastes that meet WIPP WAC, as would be applied to ${ }^{233} \mathrm{U}$ containing wastes. The WIPP WAC limits the fissile content of $\mathrm{CH}$ waste to $200 \mathrm{~g}$ equivalent of plutonium per 55-gal drum. This equals $200 \mathrm{~g}{ }^{233} \mathrm{U}$ per 55-gal drum because the WIPP WAC conservately treats ${ }^{233} \mathrm{U}$ as equivalent to plutonium when defining nuclear criticality safety limits.

The existing WIPP WAC addresses operational criticality issues for ${ }^{233} \mathrm{U}$-containing wastes. The potential for long-term criticality depends upon the migration and concentration of uranium, over time, which in turn, is a strong function of the total fissile uranium in a section of the repository-not the contents of a single drum. Given the cost and radiation exposure to workers to repackage wastes, adding DU at this time to existing WPs or other actions to limit the potential of long-term nuclear criticality are not warranted until resolution of multiple technical and institutional repository criticality issues indicates such actions are clearly required. If there are long-term criticality issues with existing wastes, other engineering options may allow long-term criticality control without opening existing WPs. Examples include emplacement of existing ${ }^{233} \mathrm{U}$ waste containers next to containers containing DU.

\subsubsection{Repackaged or New Wastes (Including Exception-Case Material to be Disposed of)}

For criticality control, sufficient DU $\left({ }^{238} \mathrm{U}\right)$ should be added to any future ${ }^{233} \mathrm{U}$ WP to isotopically dilute the ${ }^{233} \mathrm{U}$ to a concentration level of $<0.66 \mathrm{wt} \%$ in ${ }^{238} \mathrm{U}$. This approach would meet the criticality control requirements for either a WIPP-or YM-type repository. If this approach is adopted, such a policy would address numerous concerns while avoiding substantial costs. There is a technical consensus that isotopic dilution of ${ }^{233} \mathrm{U}$ with DU eliminates all nuclear criticality concerns. The cost of adding DU to a WP before it is sealed is potentially low. DOE has large excesses of DU that may require disposal if no use is found. The cost at a future date to reopen any WP to add DU is significant with added radiation exposures. There may be significant complications if high-assay ${ }^{233} \mathrm{U}$ is sent to a disposal site because the $\mathrm{CM}$ of ${ }^{233} \mathrm{U}$ is lower than any other significant uranium isotope and, thus, may control part of the criticality analysis for the disposal site. Isotopic dilution would ensure that a minor fissile isotope does not unduly control licensing of a major waste management facility. This approach parallels the criticality control strategy adopted by DOE for disposition of excess HEU that is declared waste. 



\section{ARMS CONTROL, SAFEGUARDS, AND WASTE MANAGEMENT}

\subsection{INTRODUCTION}

Uranium-233, like HEU and plutonium, can be used to build nuclear weapons. As a direct consequence, controls and requirements are placed on the storage, transport, processing, and disposal of ${ }^{233} U$-containing materials. The sources of these requirements are based on three types of considerations (Fig. 5.1):

(1) prevention of theft of weapons-usable material in the United States by domestic or foreign terrorists, (2) U.S. and international efforts to prevent the proliferation of nuclear weapons, and (3) potential nuclear arms control agreements with Russia and other weapons states.

Waste management facilities are not designed for secure processing and storing of weapons-usable materials. Therefore, the concentrations of ${ }^{233} \mathrm{U}$ in the wastes combined with the physical and chemical forms of the waste must be such that the ${ }^{233} \mathrm{U}$ is not attractive as a weapons-usable material. The conditions under which this unattractiveness occurs determine what ${ }^{233} \mathrm{U}$-containing material can be treated as waste and what ${ }^{233} \mathrm{U}$-containing material must be treated as weapons-usable fissile material.

This section addresses the safeguards and arms control influences in defining what is waste and what is concentrated fissile material containing ${ }^{233} \mathrm{U}$. However, there are two complications. First, since ${ }^{233} \mathrm{U}$ was never used on a large scale, some of the safeguards and arms control issues that have been resolved in management of plutonium and HEU have not been as fully addressed for ${ }^{233} U$. Second, with the end of the cold war, arms-control objectives are changing. Thus, the set of technical and policy issues associated with all weapons-usable fissile materials have not yet been resolved. These issues impact waste definitions.

As stated earlier (Chapter 1), the IAEA, DOE, and NRC agree that ${ }^{233} \mathrm{U}$ is equivalent to plutonium in terms of nuclear weapons. The security requirements for both materials are identical. As a consequence, safeguards and arms-control issues for both materials are similar. The precedents and practices for plutonium can in many cases be directly applied to management of ${ }^{233} \mathrm{U}$ containing materials.

\subsection{STRUCTURE OF THE DIVIDING LINE BETWEEN WEAPONS-USABLE ${ }^{233} \mathrm{U}$ AND WASTES}

There are four considerations in developing a dividing line between wastes and weapons-usable fissile materials: economics, domestic safeguards, international safeguards, and arms control. Different criteria control the dividing line in each case. 


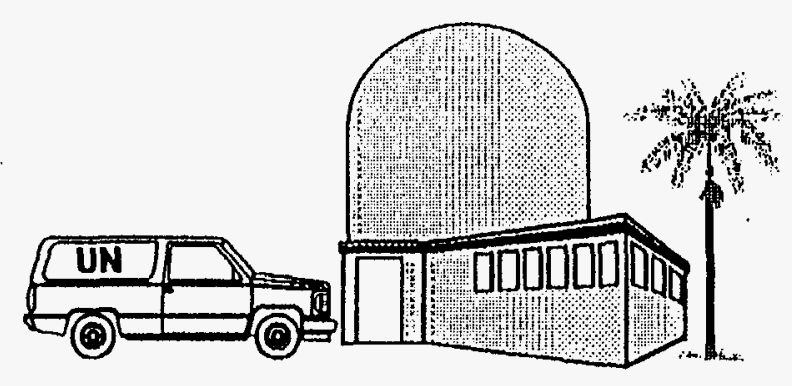

International Safeguards (Secret National Government

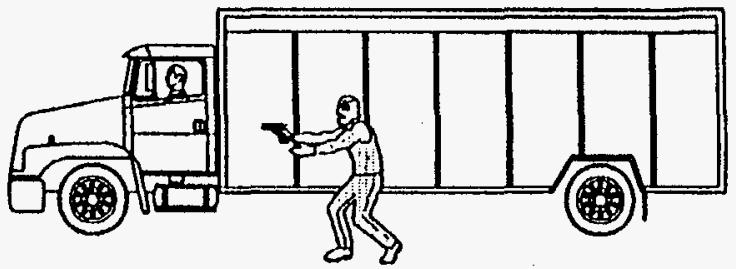

Domestic Safeguards (Theft of Nuclear Materials)

Weapons Program)
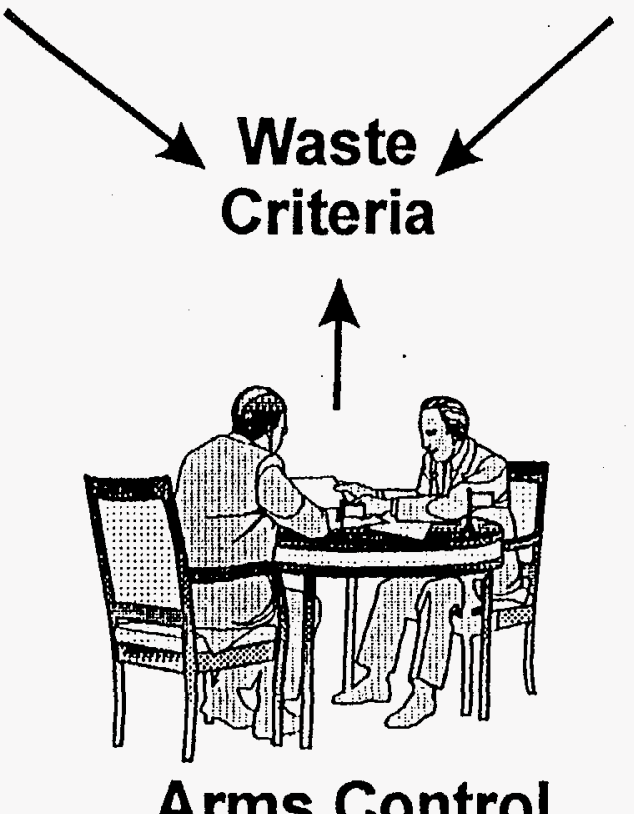

Arms Control

(Fissile Materials Cutoff

Treaty Negotiations) 


\subsubsection{Economics}

Historically, a clear division has existed between wastes and some concentrated fissile materials. This division was based on economic criteria for materials containing HEU and plutonium. These fissile materials are required to manufacture nuclear weapons and were in short supply during the cold war. For any scrap and residue stream, the stream was considered waste if the cost of the recovery of the stream's fissile material exceeded the cost of producing new fissile material (Fig. 5.2). If clean fissile materials could be recovered from a scrap and residue stream for less than the cost of producing new material, the stream was processed with recovery of fissile materials.

$\mathrm{HEU}$, plutonium, and ${ }^{233} \mathrm{U}$ are the three fissile materials that can be produced in large quantities to manufacture nuclear weapons or use as a nuclear-reactor fuel. Uranium-233 was investigated for use in nuclear weapons, as a fuel for nuclear reactors, and for other purposes. However, large-scale use was never implemented. Because there was no need, economic criteria to divide ${ }^{233} U$-containing materials into a fissilematerial category and waste category were never developed. Because of the similarities in the production of ${ }^{233} \mathrm{U}$ and plutonium, if ${ }^{233} \mathrm{U}$ had been used in the large-scale manufacture of nuclear weapons, the ${ }^{233} \mathrm{U}$ discard limits defining ${ }^{233} \mathrm{U}$ wastes would have been similar to the plutonium limits.

With the end of the cold war, the boundary between wastes and concentrated fissile materials used in the weapons community has changed because fissile materials are in excess. For example, the maximum plutonium discard limit during the cold war was $0.15 \mathrm{wt} \%$. From 1985 to 1990 , the discard limit was $0.5 \mathrm{wt} \%$. Today, DOE's plutonium discard limit is $5 \mathrm{wt} \%$ if plutonium is immobilized or encapsulated to reduce the potential for recovery.

\subsubsection{Domestic Safeguards}

\subsubsection{Institutional Structure}

Concentrated fissile materials must be guarded to prevent their theft by domestic or international terrorists. Existing and proposed waste-management processing, storage, transport, and disposal facilities are not required to have as stringent physical protection as facilities processing or storing weapons-usable materials. For a fissile-containing material to be processed and disposed of as a waste in existing and planned waste management facilities, the fissile content must be sufficiently low such that it is not an attractive target for theft. In the past, the economic criteria resulted in fissile concentrations in waste such that security requirements for waste management facilities were limited. With the end of the cold war and with little or no need for weapons-usable fissile material, economic criteria no longer assures that wastes contain only low concentrations of fissile materials. 

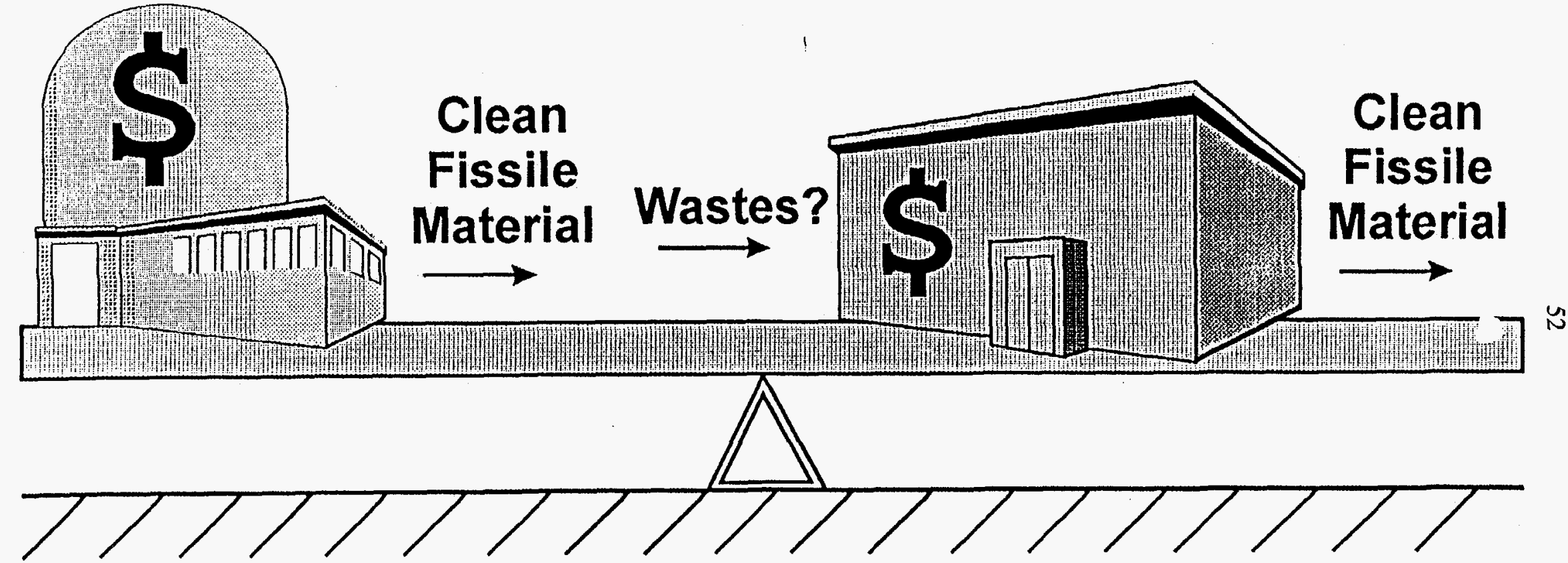

Fig. 5.2. A fissile-containing material is economically considered waste if the cost of fissile material recovery exceeds the cost of producing new fissile materials. 
The NRC regulations are consistent with IAEA recommendations for domestic safeguards. NRC physical protection and materials control and accounting requirements for a geological repository were published as a proposed rule in 60FR42079 (August 15, 1995). Publication of the final rule is eminent. DOE has a separate set of domestic safeguards requirements. This difference has important implications for ${ }^{233} \mathrm{U}$ wastes because ${ }^{233} \mathrm{U}$ wastes may be processed or disposed of in facilities regulated by either the NRC or DOE. For the proposed YM repository, NRC regulations apply. For WIPP, or a second WIPP-type repository, DOE Orders (DOE September 1994) apply. However, it has been proposed by DOE and the administration that many of the regulatory functions of DOE be transferred to the NRC. If such a change occurs, WIPP and future WIPP-type facilities may be placed under the safeguards regulatory structure of the NRC.

\subsubsection{DOE Domestic Safeguards and Wastes}

DOE has developed a graded safeguards system to apply to all fissile materials. The graded system requires different levels of security and different levels of material accounting for different fissile materials. The highest levels of security and accounting are required for nuclear weapons components with reduced requirements for other fissile materials.

DOE has also developed a series of requirements for its waste management systems that also include some security requirements. The lowest levels of safeguards security on materials with low concentrations of fissile materials are similar to the security requirements typical of many waste management operations. Therefore, it has been decided to terminate DOE safeguards on wastes sent to waste management facilities such as WIPP. In effect, security requirements are defined by DOE Orders for waste management. Consequently, the termination of DOE safeguards on wastes provides one definition of the dividing line between wastes and concentrated fissile materials.

DOE nuclear materials safeguards categories, which make up the basis for DOE physical protection and material control and accounting requirements for nuclear materials, are shown in Table 5.1. Attractiveness refers to the desirability of the material if a nuclear weapon is to be constructed. Attractiveness levels (A through $E$ ) are a measure of the processing difficulty of converting a kilogram of a particular fissile material in some matrix into weapons parts. Attractiveness Level A materials include weapons parts, whereas attractiveness Level E materials would include wastes in certain storage facilities, transport systems, and WIPP. Categories define quantities of fissile material. Category IV quantities of material have the lowest security requirements (DOE July 15, 1994). Category IV materials must be stored in a locked area. If the material is unclassified, it may be shipped by commercial carrier. Category $I V$ "shipments shall be arranged with a capacity to trace and identify, within 24 hours of request, the precise location where a shipment went astray, in the event that it fails to arrive at the destination at the prescribed time" (DOE July 15, 1994). 
Table 5.1. DOE nuclear material safeguards categories ${ }^{a}$

\begin{tabular}{|c|c|c|c|c|c|c|c|c|c|}
\hline & \multirow{2}{*}{$\begin{array}{c}\text { Attractiveness } \\
\text { level }\end{array}$} & \multicolumn{4}{|c|}{$\begin{array}{c}P U \text { and }{ }^{233} \cup \text { Categories } \\
(\mathrm{kg})\end{array}$} & \multicolumn{4}{|c|}{$\begin{array}{c}\text { Contained }{ }^{235} \text { U Category } \\
(\mathrm{kg})\end{array}$} \\
\hline . & & $\mathbf{I}$ & II & III & IV & 1 & II & III & IV \\
\hline WEAPONS & $\Lambda$ & $\begin{array}{c}\text { All } \\
\text { quantities }\end{array}$ & N/A & $N / A$ & $\mathrm{~N} / \mathrm{A}$ & $\begin{array}{c}\text { All } \\
\text { quantities }\end{array}$ & $\mathrm{N} / \mathrm{A}$ & $\mathrm{N} / \mathrm{A}$ & $\mathrm{N} / \mathrm{A}$ \\
\hline \multicolumn{10}{|l|}{ Assembled weapons and test devices } \\
\hline PURE PRODUCTS & B & $\geq 2$ & $20.4<2$ & $\geq 0.2<0.4$ & $<0.2$ & 25 & $21<5$ & $20.4<1$ & $<0.4$ \\
\hline \multicolumn{10}{|l|}{$\begin{array}{l}\text { Pits, major components, buttons, ingots, } \\
\text { recastable metal, directly convertible } \\
\text { materials }\end{array}$} \\
\hline HIGH-GRADE MATERIAL & $\mathrm{C}$ & $\geq 6$ & $22<6$ & $20.4<2$ & $<0.4$ & 220 . & $26<20$ & $\geq 2<6$ & $<2$ \\
\hline \multicolumn{10}{|l|}{$\begin{array}{l}\text { Carbides, oxides solutions ( } 225 \mathrm{~g} / \mathrm{L}) \\
\text { nitrates, etc.; fuel, elements and } \\
\text { assemblies; alloys and mixtures; } \mathrm{UF}_{4} \text { or } \\
\mathrm{UF}_{6}\left(250 \mathrm{wt} \%{ }^{233} \mathrm{U}\right)\end{array}$} \\
\hline LOW-GRADE MATERIAL & $\mathrm{D}$ & N/A & $\geq 16$ & $23<16$ & $<3$ & $\mathrm{~N} / \mathrm{A}$ & $\geq 50$ & $28<50$ & $<8$ \\
\hline \multicolumn{10}{|l|}{$\begin{array}{l}\text { Solutions ( } 1-25 \mathrm{~g} / \mathrm{l}) \text {, process residues } \\
\text { requiring extensive reprocessing } \\
\text { moderately irradiated material, }{ }^{238} \mathrm{Pu} \\
\text { (except waste), } \mathrm{UF}_{4} \text { or } \mathrm{UF}_{6}(220 \mathrm{wt} \% \\
\left.<50 \mathrm{wt} \%{ }^{235} \mathrm{U}\right)\end{array}$} \\
\hline ALL OTHER MATERIALS & $\mathrm{E}$ & $\mathrm{N} / \mathrm{A}$ & N/A & N/A & $\begin{array}{l}\text { Reportable } \\
\text { quantities }\end{array}$ & $\mathrm{N} / \mathrm{A}$ & N/A & N/A & $\begin{array}{l}\text { Reportable } \\
\text { quantities }\end{array}$ \\
\hline $\begin{array}{l}\text { Highly irradiated forms, solutions } \\
(21 \text { gl), uranium containing }<20 \mathrm{wt} \% \\
{ }^{235} \mathrm{U} \text { (any form or quantity) }\end{array}$ & & & & & & & & & \\
\hline
\end{tabular}

${ }^{\mathrm{a}} \mathrm{N} / \mathrm{A}=$ not applicable. 
Table 5.2 shows the recently amended (McCallum July 22, 1996; Crawford August 1997) concentration limits for termination of DOE safeguards on plutonium-containing materials-one dividing line between wastes and concentrated fissile materials.

The termination limits depend upon the chemical form of the material. If the plutonium is difficult to recover, higher concentrations of plutonium in the material are allowed. Determination of DOE's Safeguards Termination Limits (STLs) is a complicated task that depends upon (1) estimates of the threat of domestic or foreign terrorists stealing such material, (2) the capabilities of such terrorists to chemically recover the fissile material from the waste, (3) the capabilities of U.S. security forces to recover such material before the terrorists can use it, and (4) costs of security.

There have been recent proposals to increase the allowed concentration of plutonium in wastes to $10 \mathrm{wt} \%$ and effectively terminate DOE domestic safeguards-but with several other restrictions. These restrictions would include limiting the quantity of plutonium per container to $<200 \mathrm{~g}$ per drum (WIPP criticality limit). In effect, there would be both concentration limits on the fissile material in the waste and limits on the fissile material per package. No action has yet been taken on these proposals.

\subsubsection{DOE Domestic Safeguards as Applied to ${ }^{233} \mathrm{U}$ Wastes}

The recent amendments to DOE STLs (attractiveness Level E material) define the limits for plutonium, but do not define those limits for ${ }^{233} \mathrm{U}$. However, because DOE's nuclear materials categorization system (Table 5.1) treats plutonium and ${ }^{233} \mathrm{U}$ as identical, it would be expected that the same concentration limits for termination of DOE safeguards in Table 5.2 for plutonium would apply to ${ }^{233} \mathrm{U}$.

If the proposal to terminate DOE's safeguards on plutonium up to $10 \mathrm{wt} \%$ while limiting the plutonium content of the container to $200 \mathrm{~g}$ is approved, it may be possible to terminate safeguards on LWBR materials under similar conditions. The LWBR fresh fuel includes fuel pellets with 2 to $12 \mathrm{wt} \%{ }^{233} \mathrm{U}$ as uranium dioxide in high-fired thorium oxide. The assay of a fuel pin or package is lower because of the presence of other materials. Experience has demonstrated that recovery of the ${ }^{233} \mathrm{U}$ from high-fired thorium oxide is equal or substantially more difficult than the recovery of plutonium from special nuclear material (SNM) microencapsulated in refractory compounds or in solid dilution (Table 5.2).

There is a third way to terminate DOE safeguards for ${ }^{233} \mathrm{U}$ materials that are to be treated as wastes. Uranium-233 can be isotopically blended with ${ }^{238} \mathrm{U}$ and converted into a non-weapons usable material. This reduces the attractiveness level of materials containing ${ }^{233} U$ to attractiveness Level E. DOE safeguards system (Table 5.1) recognizes that if HEU is isotopically blended to $<20 \mathrm{wt} \%{ }^{235} \mathrm{U}$ in ${ }^{238} \mathrm{U}$, it effectively becomes non-weapons-usable material and consequently its attractiveness level is reduced to Level E-the same as wastes. Recent studies (Forsberg March 1998) have shown that isotopically diluting ${ }^{233} \mathrm{U}$ to $<12 \mathrm{wt} \%{ }^{233} \mathrm{U}$ in ${ }^{238} \mathrm{U}$ is equivalent to isotopically diluting HEU to $<20 \mathrm{wt} \%{ }^{235} \mathrm{U}$ in ${ }^{238} \mathrm{U}$. Activities are underway to incorporate this knowledge-after careful review-into the DOE Orders. 
Table 5.2. Attractiveness Level E criteria for SNM allowing for termination of DOE domestic safeguards

\begin{tabular}{|c|c|c|}
\hline \multirow[b]{2}{*}{ Description/form } & \multicolumn{2}{|c|}{ wt $\%\left(g / \mathrm{m}^{3}\right)^{\mathrm{a}}$} \\
\hline & $\begin{array}{l}\text { Maximum SNM concentration upon which } \\
\text { MC\&A and physical protection can be } \\
\text { terminated if conditions in DOE } \\
\text { Order } 5633.3 B, I, 1,1 \text { are met }\end{array}$ & $\begin{array}{c}\text { Maximum SNM concentration upon which } \\
\text { only physical protection measures equivalent } \\
\text { to Category IV requirements can be applied } \\
\text { if conditions in DOE Order } 5633.3 B, I, 1,1 \text { are } \\
\text { met }\end{array}$ \\
\hline $\begin{array}{l}\text { SNM solutions and oxides: nitrate, caustic, chloride solutions, } \\
\text { contaminated (impure) oxides, metal fines and turnings, glovebox } \\
\text { sweepings }\end{array}$ & $\begin{array}{c}0.1 \\
\left(2,500 \mathrm{~g} / \mathrm{m}^{3}\right)\end{array}$ & N/A \\
\hline $\begin{array}{l}\text { SNM amenable to dissolution and subsequent separation: pyrochemical } \\
\text { salts; chloride melt; hydroxide cake; floor sweepings; alumina; } \\
\text { condensates; reduction residues; sand, slag, and crucibles; MgO crucibles }\end{array}$ & $\begin{array}{c}0.1 \\
\left(2,500 \mathrm{~g} / \mathrm{m}^{3}\right)\end{array}$ & $\begin{array}{c}0.2 \\
\left(5,000 \mathrm{~g} / \mathrm{m}^{3}\right)\end{array}$ \\
\hline $\begin{array}{l}\text { SNM in organic matrices or requiring mechanical separation disassembly } \\
\text { and subsequent multiple recovery operations: high-efficiency particulate } \\
\text { air (HEPA) filters; organic solutions; oils and sludges; graphite or carbon } \\
\text { scrap; surface contaminated plastics; metal components; combustible } \\
\text { rubber }\end{array}$ & $\begin{array}{c}0.2 \\
\left(5,000 \mathrm{~g} / \mathrm{m}^{3}\right)\end{array}$ & $\begin{array}{c}1.0 \\
\left(25,000 \mathrm{~g} / \mathrm{m}^{3}\right)\end{array}$ \\
\hline $\begin{array}{l}\text { SNM bound in matrix of solid, sintered, or agglomerated refractory } \\
\text { materials: SNM embedded in glass or plastic, high fired incinerator ash, } \\
\text { spent resins, salt sludges, raffinates and sulfides }\end{array}$ & $\begin{array}{l}0.5 \\
\left(12,500 \mathrm{~g} / \mathrm{m}^{3}\right)\end{array}$ & $\begin{array}{c}2.0 \\
\left(50,000 \mathrm{~g} / \mathrm{m}^{3}\right)\end{array}$ \\
\hline $\begin{array}{l}\text { SNM microencapsulated in refractory compounds or in solid-dilution: } \\
\text { vitrified, bituminized, cemented, or polymer-encapsulated materials, SNM } \\
\text { alloyed with refractory elements (W, Pt, Cr, stainless steel), ceramic/glass } \\
\text { salvage }\end{array}$ & $\begin{array}{l}1.0 \\
\left(25,000 \mathrm{~g} / \mathrm{m}^{3}\right)\end{array}$ & $\begin{array}{l}5.0 \\
\left(125,000 \mathrm{~g} / \mathrm{m}^{3}\right)\end{array}$ \\
\hline
\end{tabular}

${ }^{\mathrm{a}}$ Concentration in $\mathrm{g} / \mathrm{m}^{3}$ if a waste density of $2.5 \mathrm{~g} / \mathrm{cm}^{3}$ is assumed.

Source: McCallum July 22, 1996; Crawford August 1997. 


\subsubsection{International Safeguards}

The United States, as its national and international policy, has strongly supported IAEA efforts to prevent the proliferation of nuclear weapons. IAEA safeguards are designed to detect a nation state that is diverting weapons-usable material from its domestic nuclear power and research programs into clandestine nuclear-weapons programs. However, international safeguards are not designed to address theft of weapons materials by individuals or organized groups. Under its safeguards agreement with the IAEA, the U.S. makes eligible for IAEA inspection facilities not associated with activities of national security significance. These include facilities on weapons complex sites where excess weapons usable material is stored, but not facilities where weapons design information may be revealed.

The IAEA safeguards permit the disposal of wastes either with or without termination of safeguards. For wastes containing high concentrations of fissile materials, safeguards are maintained on the wastes in the disposal facility. For wastes with low concentrations of fissile materials, safeguards may be fully terminated. The IAEA allows termination of safeguards on wastes provided that recovery of fissile materials from those wastes is substantially more difficult than production of equivalent fissile materials by the nation state by alternative routes, i.e., the fissile material in the waste is practically irrecoverable. The U.S. position has been that recovery of fissile materials from wastes with no safeguards should be at least a factor of 10 more difficult than production of fissile materials by alternative routes.

Table 5.3 shows the IAEA STLs for conditioned wastes containing plutonium or uranium with an enrichment $<5 \mathrm{wt} \%{ }^{235} \mathrm{U}$ in ${ }^{238} \mathrm{U}$ (IAEA March 1990; Larrimore July 1995). The IAEA has not explicitly defined STLs for ${ }^{233} \mathrm{U}$; however, implicit STLs can be defined based on other IAEA decisions. The IAEA perspective is that nonisotopically diluted ${ }^{233} \mathrm{U}$ is equivalent to plutonium; thus, ${ }^{233} \mathrm{U}$ STLs should be identical to those defined for plutonium. If the ${ }^{233} U$ is isotopically diluted with ${ }^{238} U$ to be equivalent to $<5 \mathrm{wt} \%{ }^{235} \mathrm{U}$ in ${ }^{238} \mathrm{U}\left(<2.4 \mathrm{wt} \%{ }^{233} \mathrm{U}\right.$ in ${ }^{238} \mathrm{U}$ containing $0.2 \mathrm{wt} \%{ }^{235} \mathrm{U}$; see Appendix B), the uranium STLs, as shown in Table 5.3, can be used for ${ }^{233}$ U. The IAEA has not defined STLs for natural uranium or DU; thus, STLs for ${ }^{233} U$ that is isotopically diluted to very low enrichments are not defined.

The IAEA recommends different levels of physical protection (August 1993) and applies different safeguards requirements depending upon fissile quantities, enrichment levels, and radiation levels. Many waste management facilities and disposal sites are designed to accept wastes with fissile contents above IAEA STLs provided the security requirements are limited. Thus, the fissile material category of a waste stream with significant fissile material is important. Table 5.4 shows IAEA categorization of fissile materials with the table extended to include ${ }^{233} \mathrm{U}$. Two important considerations impact ${ }^{233} \mathrm{U}$ waste management. 
Table 5.3. IAEA STLs for plutonium and uranium

\begin{tabular}{|c|c|c|c|c|}
\hline Category & SNM material & $\begin{array}{c}\text { Plutonium } \\
\left(\mathrm{g} / \mathrm{m}^{3}\right)\end{array}$ & $\begin{array}{c}\text { HEU } \\
\left(\mathrm{g}^{235} \mathrm{U} / \mathrm{MT}\right)^{\mathrm{a}}\end{array}$ & $<5 w t \%{ }^{235} U$ in ${ }^{238} U$ \\
\hline $\begin{array}{l}\text { Readily } \\
\text { recoverable }\end{array}$ & $\begin{array}{l}\text { Aqueous solutions, organic } \\
\text { solutions, oils }\end{array}$ & $<0.001$ & $<0.5$ & $<15 \mathrm{~g} / \mathrm{MT}$ \\
\hline $\begin{array}{l}\text { Readily } \\
\text { recoverable }\end{array}$ & $\begin{array}{l}\text { Contamination on other } \\
\text { materials }\end{array}$ & $<20$ & $<20$ & $<100 \mathrm{~g} / \mathrm{MT}$ \\
\hline Recoverable & $\begin{array}{l}\text { Salts, condensates, } \\
\text { coatings, cakes, slag }\end{array}$ & $<20$ & $<20$ & $<100 \mathrm{~g} / \mathrm{MT}$ \\
\hline $\begin{array}{l}\text { Very difficult } \\
\text { to recover }\end{array}$ & $\begin{array}{l}\text { Surface-contaminated } \\
\text { material, alloys, reactor } \\
\text { fuels, HEPA filters }\end{array}$ & 20 & $<20$ & $\begin{array}{l}<100 \mathrm{~g} / \mathrm{MT} \text { (HEPA filters) } \\
<200 \mathrm{~g} / \mathrm{MT} \\
\quad \text { (combustible/incombustible waste) }\end{array}$ \\
\hline $\begin{array}{l}\text { Extremely } \\
\text { difficult to } \\
\text { recover }\end{array}$ & $\begin{array}{l}\text { Pu embedded in matrix, } \\
\text { high fired ash, leached } \\
\text { solids, spent resins }\end{array}$ & 20 & $<20$ & $\begin{array}{l}<200 \mathrm{~g} / \mathrm{MT} \text { leached residues } \\
<2,000 \mathrm{~g} / \mathrm{MT} \text { final extraction residues }\end{array}$ \\
\hline $\begin{array}{l}\text { Practically } \\
\text { irrecoverable }\end{array}$ & $\begin{array}{l}\text { Conditioned waste, } \\
\text { refractory alloys and } \\
\text { ceramics }\end{array}$ & $\begin{array}{l}\text { Vitrified, highly irradiated: } 2,500 \\
\text { Cementitious, highly irradiated: } 2,000 \\
\text { Cementitious: } 160 \\
\text { Bituminous: } 60\end{array}$ & $\begin{array}{l}\text { Vitrified/highly irradiated: } \\
<2,500 \\
\text { Cementitious/highly irradiated: } \\
<2,000 \\
\text { Cementitious: }<160 \\
\text { Bituminous: }<60\end{array}$ & $\begin{array}{l}\text { Vitrified/highly irradiated: } \\
<1,000,000 \mathrm{~g} / \mathrm{m}^{3} \\
\text { Cementitious } / \text { highly irradiated: } \\
<1,000,000 \mathrm{~g} / \mathrm{m}^{3} \\
\text { Cementitious: }<80,000 \mathrm{~g} / \mathrm{m}^{3} \\
\text { Bituminous: }<40,000 \mathrm{~g} / \mathrm{m}^{3}\end{array}$ \\
\hline
\end{tabular}

${ }^{a} U . S$. government recommended values for LEU and HEU materials that were provided in correspondence with IAEA. 
Table 5.4. Proposed categorization of nuclear material including ${ }^{233} \mathrm{U}$ isotopic distinctions

\begin{tabular}{|c|c|c|c|c|}
\hline \multirow[b]{2}{*}{ Material } & \multirow[b]{2}{*}{ Form } & \multicolumn{3}{|c|}{ Category } \\
\hline & & I & II & $\mathbf{I I}^{\mathrm{c}}$ \\
\hline Plutonium $^{\mathrm{a}}$ & Unirradiated $^{b}$ & $2 \mathrm{~kg}$ or more & $<2 \mathrm{~kg}$, but $>500 \mathrm{~g}$ & $500 \mathrm{~g}$ or less, but $>15 \mathrm{~g}$ \\
\hline \multirow[t]{4}{*}{${ }^{235} \mathrm{U}$} & Unirradiated $^{b}$ & & & \\
\hline & Uranium enriched to $20 \mathrm{wt} \%{ }^{235} \mathrm{U}$ or more & $5 \mathrm{~kg}$ or more & $<5 \mathrm{~kg}$, but $>1 \mathrm{~kg}$ & $1 \mathrm{~kg}$ or less, but $>15 \mathrm{~g}$ \\
\hline & Uranium enriched to $10 \mathrm{wt} \%{ }^{235} \mathrm{U}$, but $<20 \mathrm{wt} \%$ & & $10 \mathrm{~kg}$ or more & $<10 \mathrm{~kg}$ \\
\hline & Uranium enriched above natural, but $<10 \mathrm{wt} \%{ }^{235} \mathrm{U}$ & & & $10 \mathrm{~kg}$ or more \\
\hline \multirow[t]{4}{*}{${ }^{233} \mathrm{U}$} & Unirradiated $^{b}$ & & & \\
\hline & Uranium with 12 wt $\%{ }^{233} \mathrm{U}$ or more & $2 \mathrm{~kg}$ or more & $<2 \mathrm{~kg}$, but $>500 \mathrm{~g}$ & $500 \mathrm{~g}$ or less, but $>15 \mathrm{~g}$ \\
\hline & Uranium with $>6 \mathrm{wt} \%{ }^{233} \mathrm{U}$, but $<12 \mathrm{wt} \%$ & & $4 \mathrm{~kg}$ or more & $<4 \mathrm{~kg}$ \\
\hline & Uranium with $>0.66 \mathrm{wt} \%$, but $<6$ wt $\%{ }^{233} \mathrm{U}$ & & & $4 \mathrm{~kg}$ or more \\
\hline
\end{tabular}

${ }^{\text {aAll }}$ plutonium except that with isotopic concentration exceeding $80 \%$ in ${ }^{238} \mathrm{Pu}$.

baterial not irradiated in a reactor or material irradiated in a reactor but with a radiation level $s 100 \mathrm{rad} / \mathrm{h}$ at $1 \mathrm{~m}$ unshielded.

${ }^{\complement}$ Quantities not falling in Category III and natural uranium, DU, and thorium should be protected at least in accordance with prudent management practice.

Source: IAEA 1993. 
- SNF categorization. SNF is the largest potential category of fissile wastes. The IAEA states that SNF should be protected at Category I, II, or III security levels and safeguards depending on the category of fresh fuel with the category reduced by one level if the SNF has a radiation level that exceeds $1 \mathrm{~Gy} / \mathrm{h}(100 \mathrm{rad} / \mathrm{h})$. In practice, this implies that facilities such as the proposed YM repository will accept IAEA Category II fissile materials, but are not designed for IAEA Category I fissile materials.

- Isotopic dilution of ${ }^{233} U$. The IAEA regulations (1993) do not recognize that mixing ${ }^{233} \mathrm{U}$ with DU will create a mixture that is unsuitable for manufacturing nuclear weapons. However, it is widely recognized within the technical and policy community that isotopic dilution of ${ }^{233} \mathrm{U}$ with DU will eliminate the ${ }^{233} \mathrm{U}$ as a weapons-usable material. Historically, little consideration has been given to converting ${ }^{233} \mathrm{U}$ to a non-weapons-usable material; thus, the required regulatory structure was not established. The technical basis for converting ${ }^{233} \mathrm{U}$ to non-weapons-usable material by diluting it with ${ }^{238}$ U has been recently developed (Forsberg 1998). Activities are currently underway to obtain official agreement that isotopic dilution eliminates the weapons potential of ${ }^{233} \mathrm{U}$. The isotopic purity that renders ${ }^{233} \mathrm{U}$ non-weapons-usable $(<12 \mathrm{wt} \%)$ is less than that for $\mathrm{HEU}(<20 \mathrm{wt} \%)$.

It is planned for the proposed YM repository to have IAEA safeguards. It is further expected that the facility will accept many wastes with significant quantities of fissile material, but the facility will not accept weapons-usable IAEA Category I material. This implies that only IAEA Category II or greater material will be allowed into the repository. The WIPP facility is currently under consideration for placement on the eligible facility list to become eligible for IAEA safeguards.

\subsubsection{Arms Control and the Spent Fuel Standard}

With the end of the cold war, the United States has implemented a policy to encourage worldwide reductions in inventories of weapons-usable materials. This policy has potentially major impacts on waste management and may create new waste management requirements. The objectives include mutually verifiable reductions in weapons-usable fissile materials with Russia and ultimately other countries. As part of this policy, the United States has proposed converting excess weapons-usable material into a form that makes recovery of weapons-usable material difficult. The final form must meet the spent fuel standard for disposal of fissile materials. The standard states that excess weapons-usable fissile materials should be no more accessible for use in nuclear weapons than plutonium found in commercial nuclear-power reactor SNF (NAS, 1994). To obtain agreement with Russia, the same rules will apply to both countries.

The post-cold-war changes in national policy imply that wastes containing fissile materials may be required to meet the spent fuel standard; otherwise, any country could adopt waste management policies that declare fissile materials as waste and bypass the intent of proposed arms control treaties that limit weaponsusable fissile-material. To date, there are no stated exceptions for materials called wastes. Each weapons state now has an interest in what fissile-containing material is defined as waste (Fig. 5.3). There are many ways the spent fuel standard can be met: 
ORNL DWG 98C-92

\section{COLD WAR}

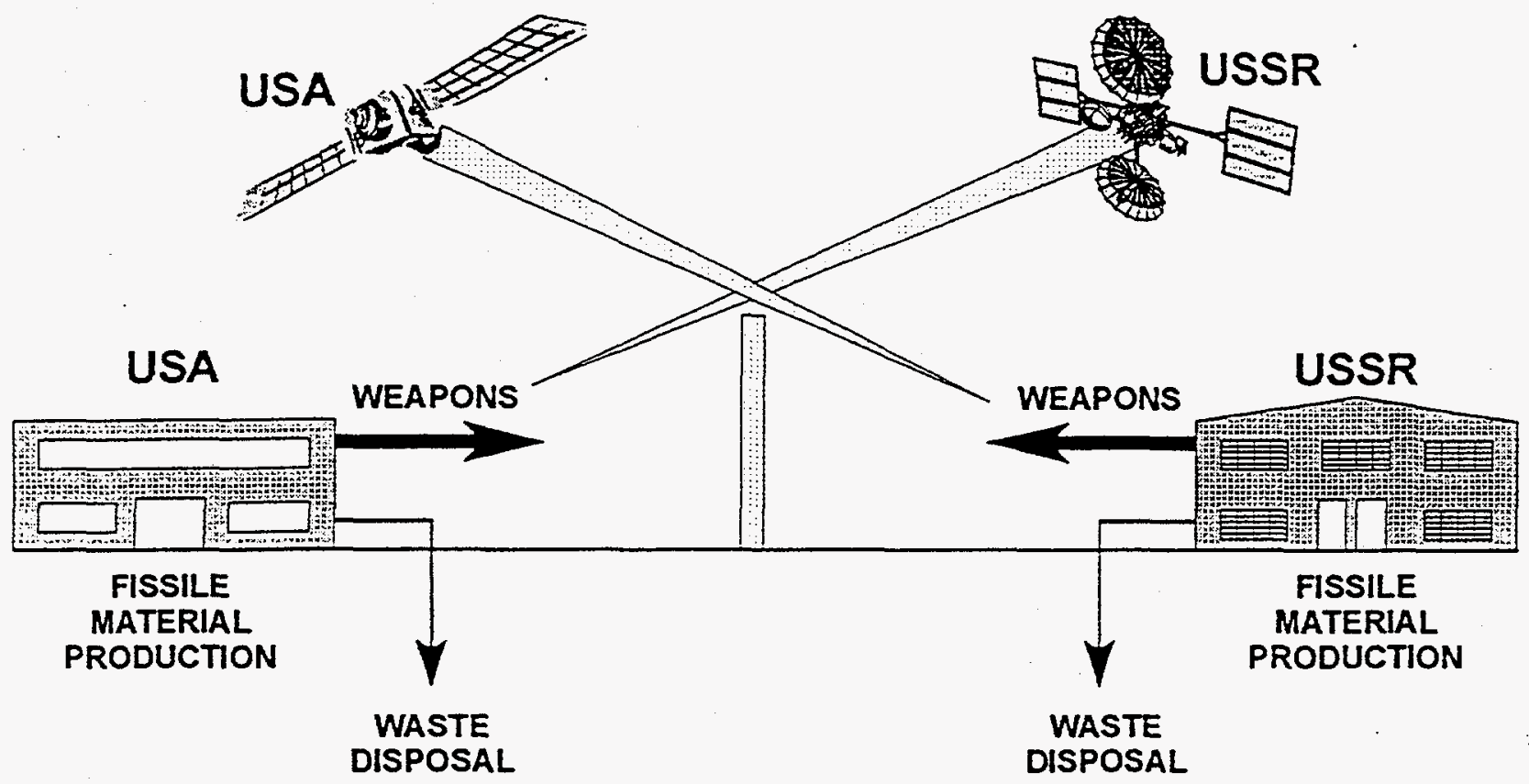

\section{POST-COLD WAR (FISSILE MATERIALS CUTOFF TREATY SCENARIO)}

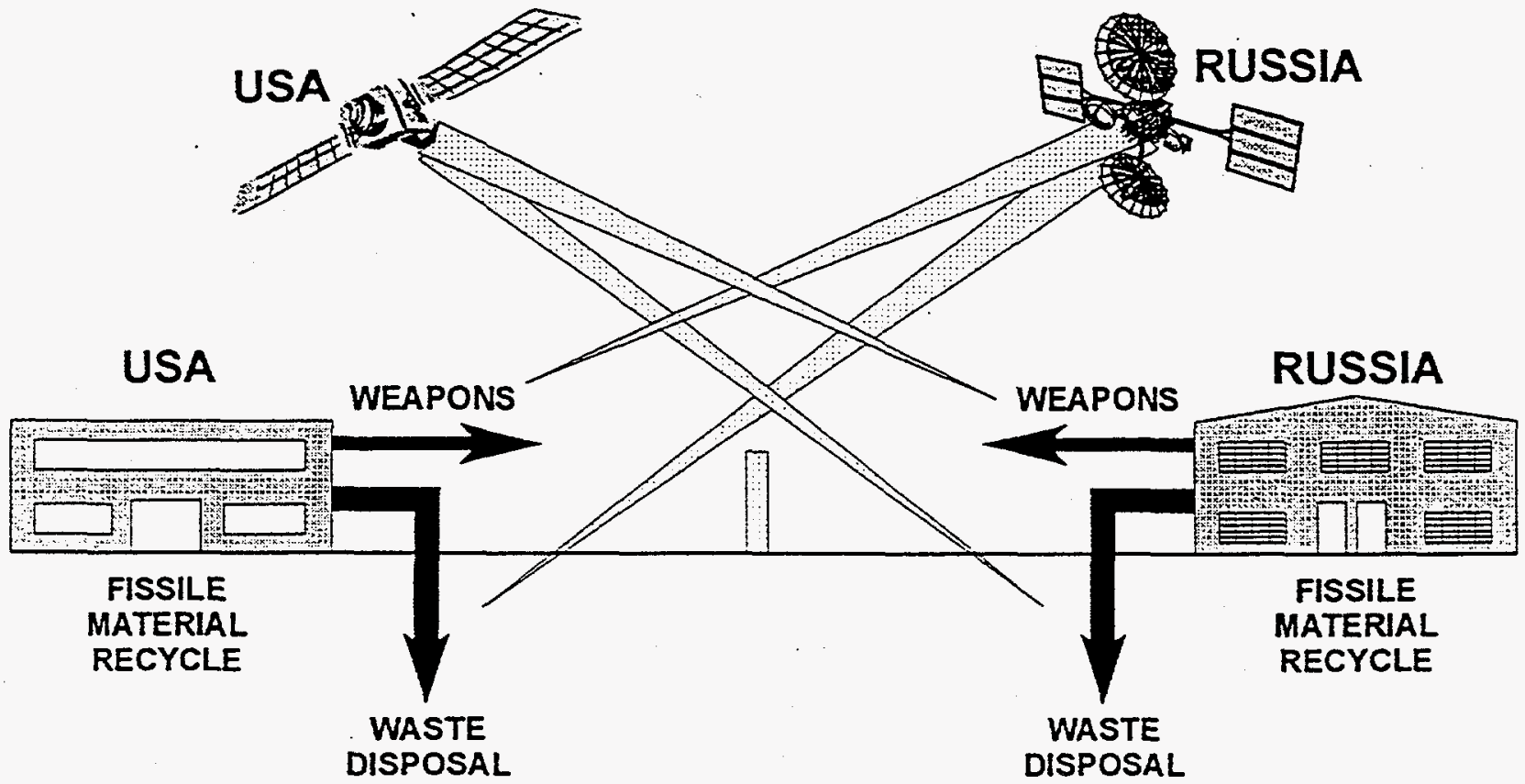

Fig. 5.3. The proposed post-cold-war fissile materials cutoff treaty implies that weapons states have an interest in fissile-material waste management in foreign countries. 
- STLs. By definition, any waste that meets IAEA STLs meets the spent fuel standard. The definition of IAEA STLs is based on making recovery of fissile wastes much more difficult than making new fissile materials such as from recovery of plutonium or ${ }^{233} \mathrm{U}$ in SNF. (However, termination of DOE domestic safeguards on a waste does not necessarily imply that the waste meets the spent fuel standard. The objectives of domestic safeguards are different from those of arms control.)

- Isotopic dilution. It has been decided that uranium isotopically diluted to non-weapons-usable uranium as defined by the IAEA meets the spent fuel standard (DOE, July 29, 1996). Enriched uranium with $<20 \mathrm{wt} \%{ }^{235} \mathrm{U}$ in ${ }^{238} \mathrm{U}$ is defined as non-weapons-usable ${ }^{235} \mathrm{U}$. The equivalent value for ${ }^{233} \mathrm{U}$ is $<12 \mathrm{wt} \%{ }^{233} \mathrm{U}$ in ${ }^{238} \mathrm{U}$.

- Cold-war economic discard limits. The cold-war economic discard limits are based on the difficulty of recovering fissile materials from wastes vs making new materials. New plutonium and ${ }^{233} \mathrm{U}$ were recovered from SNF. By definition, most fissile containing materials that were declared wastes in the cold war meet the spent fuel standard.

\subsection{ISSUES ASSOCIATED WITH DOMESTIC SAFEGUARDS}

Following the end of the cold war, DOE developed the new domestic STLs, which are shown in Table 5.2; however, there are significant uncertainties. As new national policies are implemented, they may impact STL values and definitions. This, in turn, will impact what materials may be managed as wastes because waste management facilities have limited security. Some of the key issues are described herein.

\subsubsection{Definition of an STL}

The term Safeguards Termination Limit is used by multiple organizations, but it has different meanings in each context.

- IAEA. The IAEA STL defines the concentration of fissile material below which international safeguards do not apply. International safeguards have the objective to detect illicit construction of nuclear weapons by nation states.

- Commercial. The commercial nuclear industry follows the regulations as defined by the various national regulatory authorities. In the United States, the regulator is the NRC. Most national regulatory authorities, including the $\mathrm{NRC}$, follow IAEA recommendations. In recent years, many foreign commercial organizations that recycle commercial plutonium have chosen to process wastes until the plutonium content in the waste is below IAEA STLs. From the perspective of process economics, this is not cost effective. However, eliminating IAEA safeguards on certain waste streams simplifies commercial transactions, reduces security requirements, reduces paper work, and tips the economic scale for some commercial operations.

- DOE. DOE STLs allow termination of safeguards on wastes with the requirement that waste management orders be complied with. A comparison of Tables 5.2 and 5.3 highlights the differences between DOE domestic and IAEA STLs. These reflect differences in goals. 


\subsubsection{Regulatory Authority}

There are potential regulatory uncertainties because of differences in DOE and NRC regulations. In some waste management operations, DOE has chosen commercial facilities for waste treatment. Such facilities are regulated by the NRC. DOE and the U.S. administration have proposed to Congress to transfer many regulatory functions to the NRC, but Congress has not yet considered specific legislation. The proposed YM facility will follow NRC regulations; but the WIPP facility follows DOE Orders. Different waste management strategies put ${ }^{233} \mathrm{U}$ wastes under different regulatory structures.

\subsubsection{Effectiveness of DOE STLs to Protect Against Domestic Threats}

Disagreement exists within the technical community [DOE-Idaho Operations Office (ID) 1997] about the adequacy of the new DOE STLs under all circumstances. A brief description of documented specific concerns (Westinghouse Savannah River Co. 1996; DOE-ID 1997) is provided herein:

- DOE STLs not conservative. Disagreements about the adequacy of the DOE STLs are based on the difficulty of recovery of the fissile materials from wastes by subnational groups. There are two issues:

Maximum concentration. The higher the fissile concentration, the smaller the quantity of waste that must be stolen to acquire a significant quantity of weapons-usable material. The new maximum DOE STLs are higher than the old limits.

Waste matrix. Certain waste matrixes may allow relatively easy recovery of fissile material from a waste steam. Multiple studies have evaluated the relative difficulty of recovery of fissile materials from different waste matrixes. The conclusions of these studies on the relative difficulty of recovery of plutonium from the same matrixes differ, in some cases, by orders of magnitude.

- ' DOE STLs and Waste Management Practices. DOE STLs have the explicit requirement that safeguards can be terminated only on wastes remaining under DOE waste management orders. There are characteristics of DOE's waste-management system that provide significant protection against the theft of fissile material in wastes. However, there is the concern that some fraction of the fissilecontaining wastes may be treated differently than the bulk of the waste and, thus, may not be implicitly protected.

An example can clarify this issue. Most (maybe all) plutonium-containing wastes will be sent to WIPP. The WIPP WACs to ensure criticality control during transport and disposal limit the plutonium and ${ }^{233} \mathrm{U}$ content in wastes to $<1 \mathrm{~kg}$ plutonium per cubic meter. This implies that the quantity of fissile material in any WP that meets WIPP WAC in many instances will be lower than that allowed by DOE STLs. 


\subsubsection{Concerns About Concentrated Fissile Materials Inside Larger WPs}

A particularly complex safeguards issue is the presence of concentrated fissile materials in a WP (Fig. 5.4). Let us consider two packages with identical quantities of plutonium or ${ }^{233} U$ : In one package, the fissile concentration is in a small can with packing between the can and barrel. In the second package, the plutonium or ${ }^{233} \mathrm{U}$ is uniformly distributed in the waste. While the quantities of fissile material in each package are identical, the safeguards characteristics are very different. The potential exists for terrorists with access to the packages to pull the small cans out of the barrels rapidly and acquire a significant quantity of fissile material. Fortunately, potential design solutions can minimize this risk.

This particular scenario is potentially a realistic scenario. Some of the ${ }^{233} \mathrm{U}$ material that may ultimately be considered wastes are concentrated materials inside larger packages (see Sect. 2). For many waste management facilities, the criticality limit is $200 \mathrm{~g}$ plutonium equivalent per drum ( $200 \mathrm{~g}{ }^{233} \mathrm{U} / \mathrm{drum}$ ). If a waste stream contains a moderately concentrated fissile material, one way to meet the criticality requirement is to place a small can with $200 \mathrm{~g}$ of fissile material per drum. If this is done, there are potential safeguard issues. One TRUPACK II-loaded truck (for transport of TRUW, but potentially usable for some ${ }^{233} \mathrm{U}$ wastes) contains 42 drums. If each drum is loaded with $200 \mathrm{~g}$ of ${ }^{233} \mathrm{U}$ or plutonium per drum, the truck contains $8.4 \mathrm{~kg}$ of fissile material-an amount considered sufficient to build a nuclear weapon. These trucks are typically unguarded vehicles and are not designed for high levels of security.

The TRUPACK-II container is currently licensed to accept up to 325 fissile gram equivalent ${ }^{239} \mathrm{Pu}$. This limitation is based on criticality concerns in certain accident conditions. A low fissile limit was chosen for this shipping cask to simplify licensing. Because of the low fissile content of wastes during the cold war, it was not expected that any 14 drum TRUPACK-II would approach a plutonium loading of $325 \mathrm{~g}$. Much of the more concentrated ${ }^{233} \mathrm{U}$ wastes are packaged in 55-gal shipping containers (see Sect. 2). This allows up to $200 \mathrm{~g}$ of ${ }^{233} \mathrm{U}$ per drum for all drums in a TRUPACK-II container. More recently, the Rocky Flats site has developed a similar concept called pipe-and-go that allows shipment of up to $200 \mathrm{~g}$ of plutonium per drum for all drums in a TRUPACK-II container. The questions of whether some constraint on the total quantity of fissile material in a TRUPACK needs to be limited for safeguards purposes has not been fully resolved.

\subsubsection{Resolution}

The policy issues and technical issues associated with domestic safeguards are currently being addressed. Major changes could occur. Figure 5.5 summarizes the various plutonium STLs and related parameters. 
Semihomogeneous

Waste

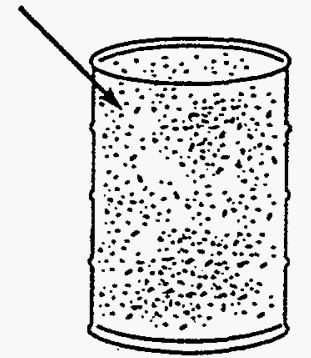

IAEA Safeguards Termination Limits

- For processed waste

- Semihomogenous waste

- Concentration limits $-<0.1 \mathrm{wt} \% \mathrm{Pu}$ in highly radioactive glass

- Lesser quantities in other waste forms

As a weapons state, the United States can use different values for domestic safeguards

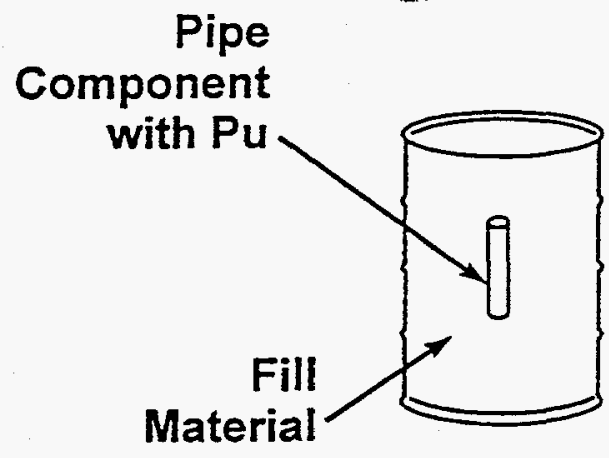

Major policy discussions on pipe-and-go option for plutonium scrap and residue disposal at WIPP

- Concentrated plutonium inside pipe component (up to $5 \mathrm{wt} \%$ )

- More than 1 significant quantity/truck - IAEA SQ = material for one bomb - 200-g Pu criticality limit/drum

- Possible option: to allow higher concentrations of fissile material but limit total fissile mass in transport or in WIPP storage

Fig. 5.4. The plutonium or ${ }^{233} \mathrm{U}$ waste form has a potential major impact on safeguards. 

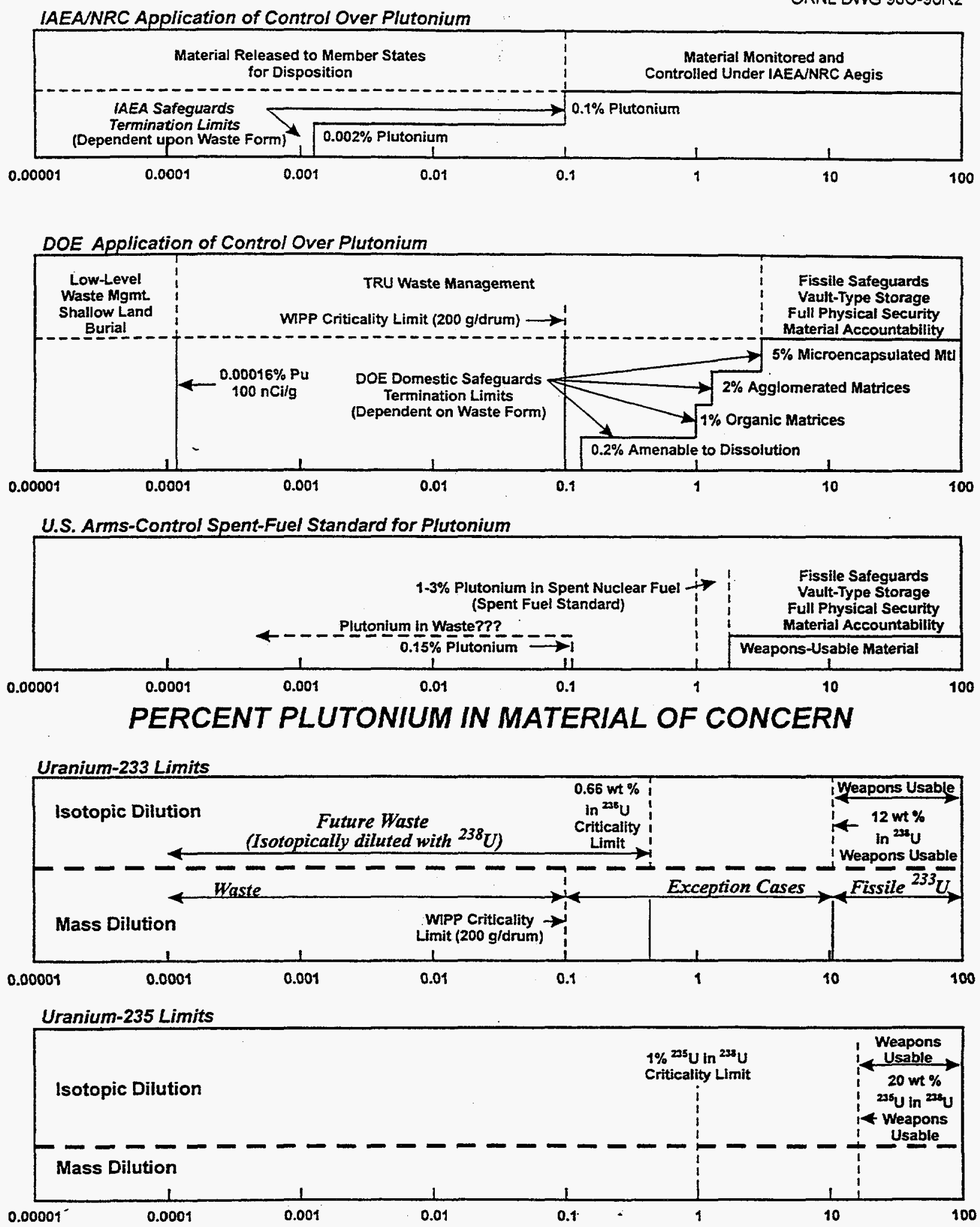

PERCENT FISSILE URANIUM IN URANIUM-238

Fig. 5.5. Plutonium and uranium safeguards, SNF, and nuclear criticality limits. 


\subsection{ISSUES ASSOCIATED WITH THE SPENT FUEL STANDARD}

The spent fuel standard is well understood as it is applied to relatively clean fissile materials. However, some policy issues associated with lower assay materials have not yet been resolved, and it is these unresolved policy issues that can impact the definition of waste and fissile materials for ${ }^{233} \mathrm{U}$.

By strict definition, any plutonium scrap and residue remaining at the end of the cold war does not meet the spent fuel standard. Plutonium scrap and residue were being stored for future processing because it was recognized that it was more economical to recover the plutonium from this material than to recover plutonium from production reactor SNF. Because the nuclear properties of ${ }^{233} U$ are similar to those of plutonium, a strict definition of fissile vs waste material that meets the spent fuel standard can be constructed for ${ }^{233} \mathrm{U}$ parallel to plutonium practice. This would allow definition of maximum allowable concentrations of ${ }^{233} \mathrm{U}$ in different chemical and physical matrixes. Similarly, any plutonium or ${ }^{233} \mathrm{U}$ above the plutonium discard limit $(0.15 \mathrm{wt} \%)$ at the end of the cold war does not meet a strict definition of the spent fuel standard.

In specific situations, DOE has declared as waste certain plutonium scrap and residue streams, and these are not required to meet the spent fuel standard. Such decisions have been based on the need to address sitespecific safety issues and other factors. An example is the disposal of plutonium sand, slag, and crucibles at the Plutonium Finishing Plant at Hanford containing $40 \mathrm{~kg}$ of plutonium (Federal Register July 10, 1996). This material is being converted to a cement-based waste form containing $2 \mathrm{wt} \%$ plutonium. The cement was nonradioactive. In comparison, plutonium that meets the spent fuel standard is highly radioactive and contains $1-3$ wt $\%$ plutonium.

A general policy on what materials must meet the spent fuel standard has not yet been formulated. Until such a policy is approved, a case-by-case determination by DOE may be required of the applicability of the spent fuel standard to individual batches of impure, fissile-containing materials with fissile concentrations above IAEA STLs. These batches include both plutonium and ${ }^{233} \mathrm{U}$ that has not been isotopically diluted below $12 \mathrm{wt} \%{ }^{233} \mathrm{U}$ in ${ }^{238} \mathrm{U}$. The final disposition of several tons of plutonium and several hundred kilograms of ${ }^{233} \mathrm{U}$ (in much larger quantities of other materials) may be impacted by the determination of what and how much material must meet the spent fuel standard.

In this context, technical options exists also to meet the spent fuel standard which do not require irradiation of fissile materials or meeting the IAEA STLs, as are currently defined. The IAEA STLs were defined for waste forms. There may be options to create engineered waste forms designed specifically to meet the spent fuel standard which are different from conventional waste forms (Sylvester et al. 1997). 


\subsection{SAFEGUARDS AND ARMS-CONTROL ${ }^{233}$ U FISSILE MATERIAL-WASTE BOUNDARIES}

\subsubsection{Existing Waste Categories}

The end of the cold war has resulted in significant changes in nuclear materials management policies. While the broad policies are well defined, the practical issues for implementing these policies are still being resolved. Therefore, sharp dividing lines between what is waste and what is fissile material does not exist. For this reason, for the purposes of domestic safeguards, IAEA safeguards, and arms control, the existing ${ }^{233} \mathrm{U}$ inventory should be divided into three categories:

- Waste

- Exception cases. Exception case material is defined as material that should be examined on a caseby-case basis to determine if it is waste. Many of the post-cold-war arms control and domestic safeguards issues have not been resolved for plutonium and HEU. Depending upon what is decided concerning the management of these materials, decisions can be made as to what ${ }^{233} \mathrm{U}$ materials are wastes or concentrated fissile materials.

- Concentrated fissile material. All other ${ }^{233} \mathrm{U}$-containing materials (excluding SNF) are defined as concentrated fissile material.

The dividing lines between these categories (Sect. 5.5.2) are chosen so that there is reasonable assurance that any material classified as a waste or concentrated fissile material will not be reclassified at a later date. However, with exception-case material, there is the potential for future decisions and rulings to impact management of these materials. Material currently in this category would be treated as it currently is, but with the explicit recognition that there are significant uncertainties. This categorization does lead to the following proposed future action on exception wastes before clarification of safeguards and arms control policies occur:

If exception materials are treated or repackaged for other reasons, the treatment or repackaging shoutd convert exception materials into (1) waste materials and or (2) concentrated fissile materials. This minimizes long-term uncertainties and potential future problems.

\subsubsection{Boundary Definitions}

The proposed dividing line between wastes and exception case material for arms control and safeguards is that it is waste if the ${ }^{233} \mathrm{U}$ (a) has an approximately homogeneous concentration of $<1 \mathrm{~kg}{ }^{233} \mathrm{U} / \mathrm{m}^{3}$ or (b) the enrichment level is $<12 \mathrm{wt} \%{ }^{233} \mathrm{U}\left(<12 \mathrm{wt} \%{ }^{233} \mathrm{U}\right.$ in $\left.{ }^{238} \mathrm{U}\right)$. More restrictive conditions apply to nonhomogeneous materials. The boundary is only for $\mathrm{DOE}$ wastes or wastes under the jurisdiction of DOE 
The dividing line is chosen so that wastes clearly meet requirements for domestic safeguards, meet the spent fuel standard, and are acceptable for any geological repository. The two clauses reflect the two ways this can be accomplished.

- Clause $A$. The proposed concentration limit for ${ }^{233} \mathrm{U}\left(1 \mathrm{~kg}{ }^{233} \mathrm{U} / \mathrm{m}^{3}\right)$ equals the plutonium concentration limit of plutonium-containing wastes accepted by WIPP (an operational nuclear criticality constraint for TRUW) and is below the maximum plutonium (and defacto ${ }^{233} \mathrm{U}$ ) economic discard limit $(0.15 \mathrm{wt} \%)$, used in the cold war as the basis for classifying wastes. Wastes meet the spent fuel standard.

- Clause $B$. The alternative safeguards and arms-control requirement is that the ${ }^{233} \mathrm{U}$ be isotopically diluted with ${ }^{238} \mathrm{U}$ and thus become non-weapons usable ${ }^{233} \mathrm{U}$. With isotopic dilution, only DOE attractiveness-Level-E, IAEA-Category-IV material exists and wastes meet the spent fuel standard.

The requirement in Clause $A$ for an approximately homogeneous concentration of ${ }^{233} U$ in the wastes explicitly recognizes that a small can of more concentrated ${ }^{233} \mathrm{U}$ in a large WP has fundamentally different safeguards and arms control implications than if the ${ }^{233} \mathrm{U}$ is distributed throughout the wastes. A more restrictive set of conditions apply if concentrated ${ }^{233} \mathrm{U}$ is in the package. Concentrated material contains $>0.15 \mathrm{wt} \%{ }^{233} \mathrm{U}$ (maximum cold-war waste threshold for plutonium). Uranium-233 containing materials with local concentrations of up to $12 \mathrm{wt} \%{ }^{233} \mathrm{U}$ plus other fissile materials in a very difficult to recover matrix (typically high-fired $\mathrm{UO}_{2}-\mathrm{ThO}_{2}$ ) can be classified as waste if the total fissile contents of the package is $<250 \mathrm{~g} / \mathrm{m}^{3}$ of fissile material. The modified boundary is to assure that only IAEA Category II quantities or less are likely to be present in typical waste management operations. This limit is equivalent to $50 \mathrm{~g} / \mathrm{drum}$. The 50-g/drum cutoff limit for concentrated ${ }^{233} \mathrm{U}$ implies that a fully loaded TRUPACK II truck contains an IAEA Category II or less quantity of fissile materials.

The boundary between exception-case wastes and concentrated fissile materials for ${ }^{233} \mathrm{U}$ is defined at $12 \mathrm{wt} \%$ fissile materials $\left({ }^{233} \mathrm{U},{ }^{235} \mathrm{U}\right.$, and $\left.{ }^{239} \mathrm{Pu}\right)$. The boundary includes all of the LWBR materials as exception-case materials. It is a natural dividing line because of one unusual characteristic of the ${ }^{233} \mathrm{U}$ inventory-there is no significant ${ }^{233} \mathrm{U}$-containing material between the highest-assay LWBR fresh fuel $\left(12 \mathrm{wt} \%{ }^{233} \mathrm{U}\right)$ and the relatively pure ${ }^{233} \mathrm{U}$.

The high-assay limit for the exception-case material is also chosen because the unusual characteristics of the specific ${ }^{233} U$ materials in this category. Depending upon the results of future evaluations, the unique properties may allow some reduction in safeguards and security requirements based on precedents for wastes containing plutonium. The $12 \mathrm{wt} \%$ is the maximum assay of the ${ }^{233} \mathrm{U}$ material in a much larger structure-including unirradiated fuel assemblies. The average ${ }^{233} \mathrm{U}$ concentration is $<5 \mathrm{wt} \%$ over a package - the maximum allowed concentration for reductions in safeguards and physical protection for any 
plutonium-containing material under DOE Orders. Second, most of the exception-case material is in the form of a high-fired, uranium dioxide-thorium dioxide matrix. Experience has shown that this is one of the most difficult matrixes in existence for recovery of uranium. Last, the radiation fields associated with this material are high compared to plutonium scrap and residue.

\subsubsection{New and Repackaged Wastes}

Some of the ${ }^{233} \mathrm{U}$ waste inventory must be ultimately repackaged to meet repository WACs. However, much of the exception-case material will have to be repackaged to meet WACs. New wastes will be generated by these operations and by future processing of ${ }^{233} U$ fissile materials (1) to stabilize fissile materials for long-term storage or (2) for fissile material disposition. The evaluations within this section indicate that the following actions should be taken with these future wastes to minimize domestic safeguards and arms control issues:

For arms control and safeguards purposes, it is recommended that-where practical-sufficient $D U\left({ }^{238} U\right)$ be added to any future waste to isotopically dilute the ${ }^{233} U$ to a concentration level of $<12$ wt \% in ${ }^{238} \mathrm{U}$. 


\section{CONCLUSIONS}

Sections 3 through 5 described different constraints that define the boundary between ${ }^{233} \mathrm{U}$-containing wastes and concentrated ${ }^{233} \mathrm{U}$ fissile materials. Combining the constraints yields the following conclusions and definitions.

\subsection{NONNUCLEAR WACs}

The characteristics of ${ }^{233}$ U-containing wastes are similar to other radioactive wastes. As a planning basis, existing ${ }^{233} U$-containing wastes should be managed like TRUW. If exception-case material is considered an economic waste, the technical characteristics would allow it to be disposed of in a WIPP- or YM-type repository.

\subsection{SAFEGUARDS, NUCLEAR CRITICALITY, AND ARMS CONTROL IMPACTS}

Safeguards, nuclear criticality, and arms control each place constraints on the definition of ${ }^{233} U$ wastes and concentrated ${ }^{233} \mathrm{U}$ fissile materials. After combining these constraints, the following definitions are proposed to define ${ }^{233} U$ containing wastes and ${ }^{233} U$ fissile materials. These definitions are for materials currently in inventory. The definitions should not necessarily be used for future wastes (see Sect. 6.3).

- Waste. Uranium-233-containing material is waste if it meets three requirements: (1) there is no existing, planned, or proposed use; (2) the ${ }^{233} \mathrm{U}$ (a) has a concentration of $<1 \mathrm{~kg}{ }^{233} \mathrm{U} / \mathrm{m}^{3}$ or (b) the enrichment level is $<0.66 \mathrm{wt} \%{ }^{233} \mathrm{U}$ in ${ }^{238} \mathrm{U}$; and (3) the ${ }^{233} \mathrm{U}$ (a) has an approximately homogeneous concentration of $<1 \mathrm{~kg}{ }^{233} \mathrm{U} / \mathrm{m}^{3}$ or (b) the enrichment level is $<12 \mathrm{wt} \%{ }^{233} \mathrm{U}$ in ${ }^{238} \mathrm{U}$. More restrictive definitions apply for inhomogeneous materials. The three requirements for a ${ }^{233} \mathrm{U}$ material to be considered waste address three criteria: economics, criticality control, and safeguardsarms control.

- Exception case. Exception case material is defined as material that should be examined on a caseby-case basis to determine if it is waste. Many of the post-cold-war arms control and safeguards issues have not been resolved for plutonium and HEU. Depending upon what is decided with the management of those materials, decisions can be made about the definition of ${ }^{233} \mathrm{U}$-containing materials. For the purposes herein, exception-case material includes materials not in the definition of wastes as described above and containing up to $12 \mathrm{wt} \%{ }^{233} \mathrm{U}$ (chemical dilution in non- ${ }^{238} \mathrm{U}$ containing materials).

- Concentrated fissile material. All other ${ }^{233}$ U containing materials (excluding SNF). 


\subsection{RECOMMENDATIONS FOR NEW WASTES AND WASTE THAT IS REPACKAGED}

Some of the ${ }^{233} \mathrm{U}$ waste inventory must be repackaged to meet repository WACs. Much of the exception-case material will have to be repackaged to meet WAC if it is economically considered a waste. New wastes will be generated by these repacking operations and by future processing of ${ }^{233} U$ fissile materials (1) to stabilize fissile materials for long term storage or (2) for fissile material disposition. The evaluations within this report indicate that the following action should be taken with these future wastes to minimize domestic safeguards, arms control, and criticality issues associated with future wastes:

It is recommended that-where practicably-sufficient $D U\left({ }^{238} U\right)$ be added to any future WP to isotopically dilute the ${ }^{233} U$ to an isotopic concentration level of $<0.66 w t \%$ in ${ }^{238} U$.

There are several bases for this recommendation. Isotopic dilution of ${ }^{233} \mathrm{U}$ to 0.66 wt $\%{ }^{233} \mathrm{U}$ in ${ }^{238} \mathrm{U}$ credibly eliminates the potential for nuclear criticality. Isotopic dilution of ${ }^{233} U$ to $<12 \mathrm{wt} \%$ with ${ }^{238} \mathrm{U}$ converts weapons-usable ${ }^{233} U$ into non-weapons-usable, low-enriched ${ }^{233} U$. This conversion minimizes safeguards and security requirements for processing, storage, transport, and disposal. (The requirements for criticality control impose a more restrictive condition than those for safeguards.) Last, isotopic dilution of ${ }^{233} \mathrm{U}$ with DU meets potential future arms control requirements and meets the spent fuel standard for disposal of fissile materials.

\subsection{WASTE AND FISSILE INVENTORIES BASED ON THE ABOVE CLASSIFICATION}

Table 2.1 shows the inventory of ${ }^{233} \mathrm{U}$-containing materials based on the above classification. Relatively small quantities as measured by volume are in the exception-case category. There are several important characteristics of the exception-case material. Most (if not all) of the ${ }^{233} \mathrm{U}$ is in the form of uranium dioxide mixed with thorium dioxide. This is chemically a very stable material. Much of the ${ }^{233} \mathrm{U}$ in drums is in pipe components; i.e., the ${ }^{233} \mathrm{U}$ is concentrated. Last, much (if not all) of this material must be repacked for disposal if it is to be disposed as waste. Consequently, the option will exist to convert it into a form that addresses criticality, safeguards, and arms control issues. 


\section{REFERENCES}

Ahn, T. M., November 1996. Dry Oxidation and Fracture of LWR Spent Fuel, NUREG-1565, U.S. Nuclear Regulatory Commission, Washington D.C.

American Nuclear Society, 1981. Nuclear Criticality Control of Special Actinide Elements: An American National Standard, ANSI/ANS-8.15-1981, La Grange Park, Illinois.

American National Standards Institute, Inc., October 7, 1983. American National Standard for Nuclear Criticality Safety in Operations with Fissionable Materials Outside Reactors, ANSI/ANS-8.1-1983, American Nuclear Society, La Grange Park, Illinois.

Ashline, R. C. and C. W. Forsberg, April 1996. "U.S. Light-Water Reactor Spent Fuel Inventory-Fissile Distribution," Proc. 1996 International High-Level Radioactive Waste Management Conference, Las Vegas, Nevada. April 29-May 3, 1996, American Society of Civil Engineers.

Bereolos, P. J., et al. October 27, 1997. Strategy for Future Use and Disposition of U-233: History, Inventories, Storage Facilities, and Potential Future Uses, ORNL/MD/LTR-61, Oak Ridge National Laboratory, Oak Ridge, Tennessee (draft).

Bolton, S. R., A. B. Christensen, and E. J. Hallinan, March 1989. Final Safety Analysis Report: Storage of Unirradiated and Irradiated Light-Water Breeder Reactor Fuel in Underground Dry Wells at ICPP, INEL-WIN-107-4.7A, Rev. 1, Idaho Falls, Idaho.

Boyd, W. A. and M. W. Fecteau, November 1993. "Criticality Safety of Transuranic Storage Arrays at the Waste Isolation Pilot Plant," Nucl. Technol. 104:207-218.

Brookins, D. G., 1984. Geochemical Aspects of Radioactive Waste Disposal, Springer-Verlag, New York.

Brookins, D. G., 1990. "Radionuclide Behavior at the Oklo Nuclear Reactor, Gabon," Waste Management, 10,285.

Buscheck, T. A. and J. J. Nitao, December 1993. "Repository-Heat-Driven Hydrothermal Flow at Yucca Mountain, Part I,"Nucl. Technol., 104:(3), 418.

Buscheck, T. A., J. J. Nitao, and D. G. Wilder, December 1993. "Repository-Heat-Driven Hydrothermal Flow at Yucca Mountain, Part II," Nucl. Technol., 104(3), 449.

Clayton, E. D., 1973. "Fissionability and Criticality: From Protactinium to Californium and Beyond,"Nucl. Sci. Eng., 52,417.

Cloud, P., 1988. Oasis in Space: Earth History From the Beginning, W. W. Norton \& Co., New York, New York.

Coony, F. M., April 3, 1998. Rust Federal Services of Hanford, Inc., Richland, Washington, correspondence to Stephen N. Storch, Oak Ridge National Laboratory, Oak Ridge, Tennessee. 
Cowan, G. A., July 1976. “A Natural Fission Reactor," Scientific American, 235, 36.

Crawford, D. W., August 1997. Safeguards Termination Limits on Immobilized Nuclear Material, J. Nuclear Materials Management, p. 13.

Defense Nuclear Facilities Safety Board, March 3, 1997. Recommendation 97-1 to the Secretary of Energy, Washington D.C.

Deffeyes, K. S. and I. D. MacGregor, January 1980. "World Uranium Resources," Scientific American, 242(1), 66 .

Detrick, C. A., May 6, 1997. "Unirradiated Shippingport LWBR Fuel,"WAPD-EA-318, Bettis Atomic Power Laboratory, West Mifflin, Pennsylvania, correspondence to Stephen N. Storch, Oak Ridge National Laboratory, Oak Ridge, Tennessee.

Drez, P., March 20, 1998. Drez Environmental Associates, Albuquerque, New Mexico, correspondence to Stephen N. Storch, Oak Ridge National Laboratory, Oak Ridge, Tennessee, "Requested U-233 Information from LANL and RL."

Drez, P. E., April 3, 1998. Drez Environmental Associates, Albuquerque, New Mexico, correspondence to Stephen N. Storch, Oak Ridge National Laboratory, Oak Ridge, Tennessee.

Elam, K. R., C. W. Forsberg, C. M. Hopper, and R. Q. Wright, 1997. Isotopic Dilution Requirements for ${ }^{233}$ U Criticality Safety in Processing and Disposal, ORNL/TM-13524, Lockheed Martin Energy Research Corporation, Oak Ridge National Laboratory, Oak Ridge, Tennessee.

Federal Register, July 10, 1996. Record of Decision for the EIS for PFP Stabilization, 61(133):36352.

Forsberg, C. W., 1997. "Long-Term Criticality Control in Radioactive Waste Disposal Facilities Using Depleted Uranium," p. 91 in Proc. of the Topical Meeting on Criticality Safety Challenges in the Next Decade, Chelan, Washington, September 7-11, 1997, American Nuclear Society, La Grange Park, Illinois.

Forsberg, C. W., C. M. Hopper, J. L. Richter, and H. C. Vantine, February 1998. Definition of WeaponsUsable Uranium-233, ORNL/TM-13517, Lockheed Martin Energy Research Corp., Oak Ridge National Laboratory, Oak Ridge, Tennessee.

GE Nuclear Energy, 1996. Nuclides and Isotopes: Fifteenth Edition, San Jose, California.

Gray, W. J., L. W. Thomas, and R. E. Einziger, 1993. "Effects of Air Oxidation on the Dissolution Rate of LWR Spent Nuclear Fuel," Symposium Proc. Scientific Basis for Nuclear Waste Management XVI, Boston, Massachusetts, November 30-December 4, 1992, 294:47, Materials Research Society, Pittsburgh, Pennsylvania.

Hammond, D. A., March 13, 1998. Lockheed Martin Idaho Technologies Company, INEEL, Idaho Falls, Idaho, correspondence to Charles Forsberg, Lockheed Martin Energy Research Corporation, Oak Ridge National Laboratory, Oak Ridge, Tennessee. 
Harper, C. L. and S. B. Jacobsen, September 27, 1996. "Noble Gases and Earth's Accretion," Science, 273, 1814.

Harvill, J., March 2, 1998. Carlsbad Technical Assistance Contractor, National TRU Program, Carlsbad, New Mexico, correspondence to Stephen N. Storch, Oak Ridge National Laboratory, Oak Ridge, Tennessee.

Hertzler, T., D. D. Nishimoto, and M. D. Otis, May 1994. Depleted Uranium Disposal Options Evaluation, EGG-MS-1 1297, Idaho National Engineering Laboratory, Idaho Falls, Idaho.

Hofmann, A. W., January 24, 1997. "Early Evolution of Continents," Science, 275, 498.

International Atomic Energy Agency, 1975. The Oklo Phenomenon, Proc. of a Symposium on the Oklo Phenomenon, June 23-27, 1975, Libreville, Gabon, Vienna, Austria.

International Atomic Energy Agency, 1978. Natural Fission Reactors, Proc. Technical Committee on Natural Fission Reactors, Paris, France, December 19-21, 1977, Vienna, Austria.

International Atomic Energy Agency, March 1990. Consultants'Report on Meeting for Development of Technical Criteria for Termination of Safeguards for Material Categorized as Measured Discards, STR-251 (Rev. 2), Vienna, Austria.

International Atomic Energy Agency, August 1993. The Physical Protection of Nuclear Materials, INFCIRC/225/Rev. 3, Vienna, Austria.

Larrimore, J. A., July 1995. "Termination of International Safeguards on Nuclear Material Discards: An IAEA Update," pp. 202-207 in Proc. Institute of Nuclear Materials Management, July 9-12, 1995, Vol. 36.

Lewis, S. T., 1997. "Uranium Enriched to Less Than One Weight Percent ${ }^{235} \mathrm{U}$-Safe for Operation at Uranium Enrichment Plants," p. 163 in Proc. of Topical Meeting on Criticality Safety Challenges in the Next Decade, Chelan, Washington, September 7-11, 1998, American Nuclear Society, La Grange Park, Illinois.

Lockheed Martin Energy Systems, February 1996. Waste Acceptance Criteria for the Oak Ridge Reservation, ES/WM-10, Rev. 1, Oak Ridge, Tennessee.

Lockheed Martin Idaho Technologies Company, November 12-14, 1996. "U-233 Storage and IFSF Seismic Review," presentation to Defense Nuclear Facilities Safety Board Technical Staff, Idaho National Engineering Laboratory, Idaho Falls, Idaho.

Lotts, A. L., et al., February 1992. Options for Treating High-Temperature Gas-Cooled Reactor Fuel for Repository Disposal, ORNL/TM-12027, Oak Ridge National Laboratory, Martin Marietta Energy Systems, Inc., Oak Ridge, Tennessee.

McCallum, E. J., July 22, 1996. Additional Attractiveness Level E Criteria for Special Nuclear Materials (SNM), U.S. Department of Energy, Germantown, Maryland. 
Mitchell, J. A., J. P. Semans, and G. G. Smith, October 1974. ${ }^{233}$ U Oxide-Thorium Oxide Detailed Cell Critical Experiments (LWBR Development Program), WAPD-TM-1101, Bettis Atomic Power Laboratory, West Mifflin, Pennsylvania.

Naudet, S. R., 1978. "Etude Parametrique De La Criticite Des Reacteurs Naturels," IAEA-TC-1 19/22, Natural Fission Reactors, Proc. Technical Committee on Natural Fission Reactors, Paris, France, December 19-21, 1977, International Atomic Energy Agency, Vienna, Austria .

Nielsen, J., April 3, 1998. Los Alamos National Laboratory, Los Alamos, New Mexico, correspondence to Stephen N. Storch, Oak Ridge National Laboratory, Oak Ridge, Tennessee.

Oak Ridge National Laboratory, February 18, 1994. ORNL Nuclear Criticality Safety Program Procedure NCS-1.0, Rev. 0, Appendix A: Control Limits on Fissionable Nuclides at ORNL, Martin Marietta Energy Systems, Oak Ridge, Tennessee.

Ogilvie, F. M. and N. Harris, 1997. "Handling and Disposal of Decommissioning Wastes at BNFL Sellafield," p. 31 in Proc. of the Topical Meeting on Criticality Safety Challenges in the Next Decade, Chelan, Washington, September 7-11, 1997, American Nuclear Society, La Grange Park, Illinois.

Olander, D. R., 1996. "Release, Transport, and Deposition of Pu and HEU in Geologic Media," Proc. DOE Nuclear Fuel and Fissile Material Management, June 16-20, 1996, Reno, Nevada, American Nuclear Society, La Grange Park, Illinois.

Rechard, R. P., June 1996. An Introduction to the Mechanics of Performance Assessment Using Examples of Calculations Done for the Waste Isolation Pilot Plant Between 1990 and 1992, SAND93-1378 (rev.), Sandia National Laboratories, Albuquerque, New Mexico.

Rechard, R. P., C. T. Stockman, L. C. Sanchez, J. S. Rath, and J. Liscum-Powell, November 26, 1996. FEP Screening Argument - RNT-1: Nuclear Criticality in Near-Field and Far-Field, SWCR-A:1.2.07.3:PA:QA:TSK:RNT-1, Sandia National Laboratories, Albuquerque, New Mexico.

Rechard, R. P., June 1997. "Exploring the Potential for Criticality in Geological Repositories for Nuclear Waste," Proc. ISREL '97, International Conference on Safety and Reliability, Lisbon, June 17-20, ISBN 008-042835-5.

Sadler, D., June 11, 1997. Lockheed Martin Idaho Technologies Company, Idaho Falls, Idaho, correspondence to Stephen N. Storch, Oak Ridge National Laboratory, Oak Ridge, Tennessee, transmitting information on dry storage well positions of Bettis shipments of unirradiated LWBR fuel to the INEEL/ICPP.

Schick, Jr., W. C., et al., September 1987. Proof of Breeding in the Light-Water Breeder Reactor (LWBR Development Program), WAPD-TM-1612, Bettis Atomic Power Laboratory, West Mifflin, Pennsylvania.

Scott, M. and T. Doering, 1997. "Rethinking Regulation for Disposal Criticality," in Proc. Topical Meeting Criticality Safety Challenges in the Next Decade, Chelan, Washington, September 7-11, 1997, American Nuclear Society, La Grange, Illinois.

Smellie, J., March 1995. "The Fossil Nuclear Reactors of Oklo, Gabon," Radwaste Mag., 2(2), 18. 
Smith, D. K., B. E. Scheetz, C. A. F. Anderson, and K. L. Smith, 1982. "Phase Relations in the UraniumOxygen-Water System and Its Significance on the Stability of Nuclear Waste Forms," Uranium, 1, 79.

Smith, D. K., W. P. Freeborn, and B. E. Scheetz, 1983. "Compatibility Relationships in the U-Fe-O(-H) System at $400^{\circ} \mathrm{C}$ : The Implications of the Ferric-Ferrous Buffer for the Immobilization of Uranium and Transuranic Elements," Mater. Res. Soc. Symp. Proc. 15, 91.

Sylvester, P. J., I. H. Campbell, and D. A. Bowyer, January 24, 1997. "Niobium/Uranium Evidence for Early Formation of the Continental Crust," Science, 275: 521.

U.S. Congress, 1996. Department of Energy National Security and Military Applications of Nuclear Energy Authorization Act of 1980 as amended, Public Law 96-164, Washington, D.C.

U.S. Congress, 1996. Waste Isolation Pilot Plant Land Withdrawal Act, Public Law 102-579, as amended.

U.S. Department of Energy, September 26, 1988. DOE Order 5820.2A, Radioactive Waste Management, Washington, D.C.

U.S. Department of Energy, July 15, 1994. Protection and Control of Safeguards and Interacts, DOE Order 5632.1C, Washington, D.C.

U.S. Department of Energy, September 7, 1994. Control and Accountability of Nuclear Materials, DOE Order 5633.3B, Washington, D.C.

U.S. Department of Energy, Carlsbad Area Office, April 1996. Waste Acceptance Criteria for the Waste Isolation Pilot Plant, DOE/WIPP-069, Rev. 5, Carlsbad, New Mexico.

U.S. Department of Energy, Office of Fissile Materials Disposition, June 1996. Disposition of Surplus Highly-Enriched Uranium Final Environmental Impact Statement, DOE/EIS-0240, Washington, D.C.

U.S. Department of Energy, July 29, 1996. Record of Decision for the Disposition of Surplus HighlyEnriched Uranium Final Environmental Impact Statement, Washington, D.C.

U.S. Department of Energy, Carlsbad Area Office, September 1997. Waste Isolation Pilot Plant Disposal Phase Final Supplemental Environmental Impact Statement, DOE/EIS-0026-S-2, Carlsbad, New Mexico.

U.S. Department of Energy, December 1997. Integrated Data Base Report-1996: U.S. Spent Nuclear Fuel and Radioactive Waste Inventories, Projections, and Characteristics, DOE/RW-0006, Rev. 13, Washington, D.C.

U.S. Department of Transportation, December 21, 1990. 49 CFR Part 178.360, "Specification 2R; Inside Containment Vessel," Final Rule, Fed. Regist. 55, 52716.

U.S. National Academy of Sciences, 1994. Management and Disposition of Excess Weapons Plutonium, Washington, D.C. 
U.S. National Academy of Sciences, 1995. Technical Bases for Yucca Mountain Standards, National Academy Press, Washington, D.C.

U.S. Nuclear Regulatory Commission, 1995. "Performance of Particular Barriers After Permanent Closure," Code of Federal Regulations, 10 CFR Part 60.113, Washington, D.C.

U.S. Nuclear Regulatory Commission, June 1997. The Potential for Criticality Following Disposal of Uranium at Low-Level Waste Facilities, NUREG/CR-6505, Washington, D.C.

U.S. Nuclear Waste Technical Review Board, 1996. Report to the U.S. Congress and the Secretary of Energy: 1995 Findings and Recommendations, Arlington, Virginia.

Von Marvic, H., 1993. Oklo Working Group Meeting: Proc. Second Joint CEC-CEA Progress Meeting Held in Brussels, April 6-7, 1992, EUR 14877, Commission of the European Communities, Brussels, Belgium.

Westinghouse Savannah River Company, September 1996. Impact of Limits for the Reduction or Termination of Safeguards on Low-Grade Residues, WSRC-RP-96-489, Aiken, South Carolina.

Westinghouse Savannah River Company, August 1997. Nuclear Criticality Safety Evaluation: Contact Handled Waste at the Waste Isolation Pilot Plant (WIPP), PECD-WIP-970004, Revision 0, Aiken, South Carolina.

Wronkiewicz, D. J., et al., 1992. "Uranium Release and Secondary Phase Formation During Unsaturated Testing of $\mathrm{UO}_{2}$ at $90^{\circ} \mathrm{C}, " J$. Nuclear Mater., 190, 107.

Yong, L., March 24, 1998. Advanced Integrated Management Services, Inc., Oak Ridge, Tennessee, correspondence to Stephen N. Storch, Oak Ridge National Laboratory, Oak Ridge, Tennessee.

Yong, L., May 12, 1998. Advanced Integrated Management Services, Inc., Oak Ridge, Tennessee, correspondence to Stephen N. Storch, Oak Ridge National Laboratory, Oak Ridge, Tennessee. 
Appendix A:

DETAILED CHARACTERISTICS OF SITE ${ }^{233}$ U-BEARING MATERIALS 


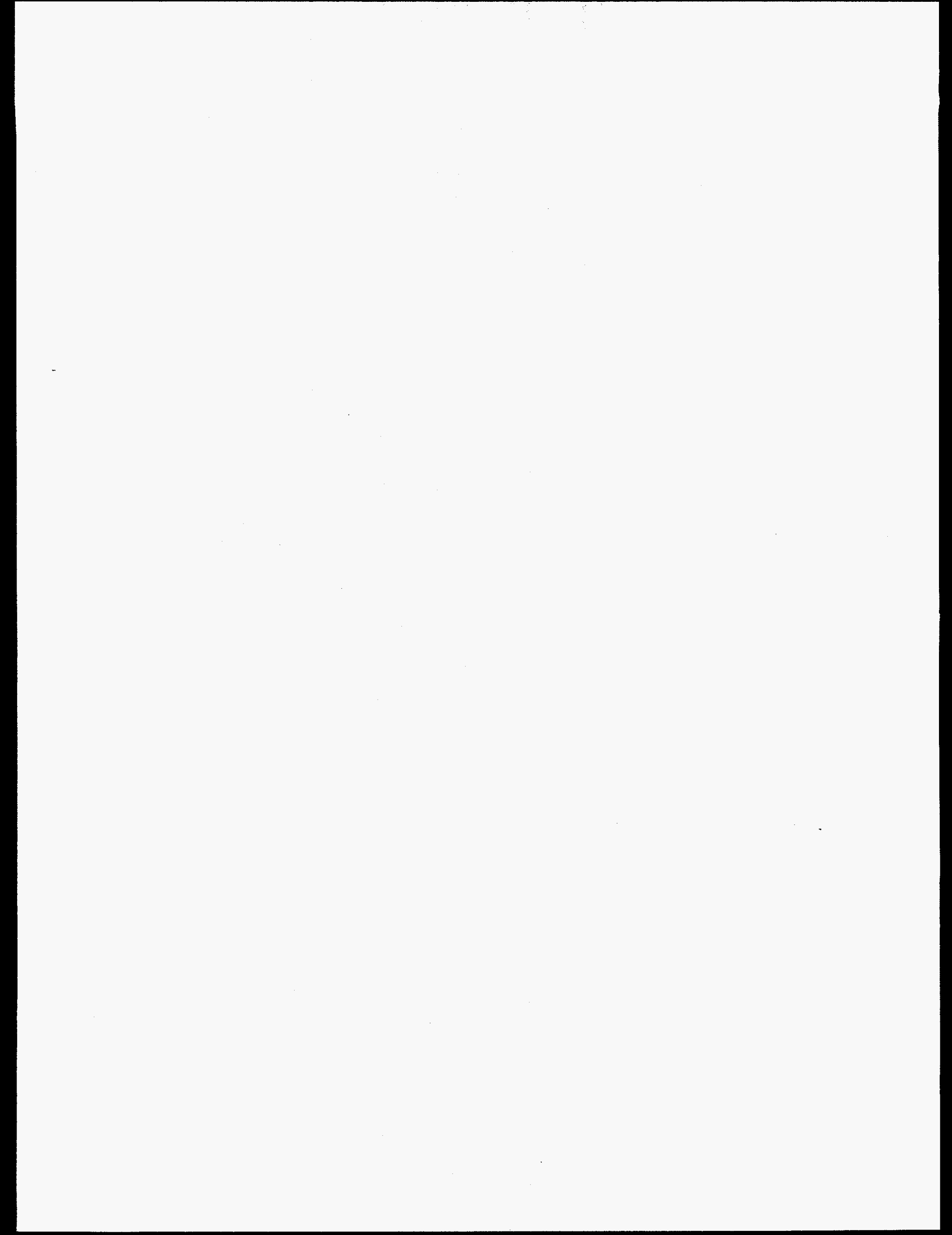




\section{Appendix A: DETAILED CHARACTERISTICS OF SITE ${ }^{233}$ U-BEARING MATERIALS}

\section{A.1 DISCUSSION}

This appendix reports detailed site ${ }^{233} U$ material inventory information that provided the basis for the discussion on ${ }^{233} \mathrm{U}$ material inventories in Sect. 2 of the main body of this report. The data presented in the tables of this appendix are based on the references cited in Sect. A.2.

Table A.1 (Bereolos, et al. June 1998) provides a listing of ${ }^{233} \mathrm{U}$ nonwaste (fissile) materials at

12 domestic sites. The information reported in certain columns of tables in this appendix is based on specific codes defined for material forms, packaging types, and nuclear material types in Tables A.2-A.4, respectively. Most of the ${ }^{233} \mathrm{U}$-bearing fissile material is stored either at INEEL (and ICPP) or ORNL. Detailed data for the fissile materials stored at INEEL and ORNL sites are provided in Tables A.5 (Chemical Technology Division September 22, 1995; DOE Idaho Operations Office July 19, 1995; Liable August 1, 1996; and Bright November 12, 1996) and A.6 (Krichinsky August 25, 1997), respectively.

Tables A.7 and A.8 (based on Bolton, Christensen, and Hallinan March 1989) report additional information on the unirradiated LWBR fuel at INEEL. Detailed fuel characteristics are given in Table A.7, and detailed features of the storage canisters used to store this fuel are given in Table A.8.

Information on the characteristics of DOE site TRUW (mixed and nonmixed) containing ${ }^{233} \mathrm{U}$-bearing materials is provided in Tables A.9-A.12 (Harvill March 2, 1998; and DOE December 1997).

Characteristics for CH TRUW are given in Tables A.9 and A.11, and characteristics for RH TRUW are given in Tables A.10 and A.12. Based on major differences between the as-generated and final-form TRUW volumes reported for some sites in Tables A.9 and A.10, it is estimated that about two-thirds of the total final-form TRUW volume (most of which resides at INEEL) will be repackaged.

Table A.13 (based on Drez April 3, 1998; Hammond March 13, 1998; Nielsen April 3, 1998; and Yong May 6, 1998) provides detailed information on the ${ }^{233} \mathrm{U}$ concentrations in containers at four DOE sites which have significant quantities of ${ }^{233} \mathrm{U}$-bearing wastes. For purposes of this report, the site ${ }^{233} \mathrm{U}$ waste data given in Table A.13 are based on the following assumptions:

- $\quad{ }^{233} \mathrm{U}$ wastes in 30 -gal drums will be repackaged into 55-gal drums

- ${ }^{233} \mathrm{U}$ wastes in a 110-gal drum will be repackaged into two 55-gal drums

- ${ }^{233} \mathrm{U}$ wastes that are in a crate are assumed to be repackaged into a 55-gal drum

- All INEEL ${ }^{233} \mathrm{U}$ wastes are assumed to be in 55-gal drums

Table A.14 (based on Yong March 24, 1998 and May 6, 1998) gives the ${ }^{233} U$ concentration and mass content for drums containing ${ }^{233} \mathrm{U}$-bearing materials at ORNL. Breakdowns of the concentration and mass content are given for all drums containing ${ }^{233} \mathrm{U}$, those drums containing both ${ }^{233} \mathrm{U}$ and $\mathrm{Pu}$ in concentrations $>100 \mathrm{nCi} / \mathrm{g}$, and those drums containing ${ }^{233} \mathrm{U}$ (and no plutonium) in concentrations $>100 \mathrm{nCi} / \mathrm{g}$. 


$$
\text { A-4 }
$$

Table A.1. Summary, by site, of domestic ${ }^{233} U$ material (nonwaste) characteristics and inventories ${ }^{\mathrm{a}}$

\begin{tabular}{|c|c|c|c|c|}
\hline Site & $\begin{array}{c}\text { No. of } \\
\text { packages }\end{array}$ & $\begin{array}{c}\text { Total U } \\
(\mathrm{kg})\end{array}$ & $\begin{array}{l}{ }^{233} \mathrm{U} \\
(\mathrm{kg})\end{array}$ & $\begin{array}{l}{ }^{235} \mathrm{U} \\
(\mathrm{kg})\end{array}$ \\
\hline Argonne National Laboratory-East & 5 & 0.028 & 0.028 & 0 \\
\hline Argonne National Laboratory-West & 63 & $0.155^{b}$ & $0.154^{b}$ & 0 \\
\hline Bettis Atomic Power Laboratory & 13 & 0.406 & 0.385 & 0.014 \\
\hline General Atomics & 2 & $<0.001$ & $<0.001$ & $<0.001$ \\
\hline Hanford Site & 3 & 0.597 & 0.079 & 0 \\
\hline Idaho National Engineering and Environmental Laboratory & 186 & 358.6 & 351.6 & 0 \\
\hline Lawrence Livermore National Laboratory & 50 & 3.321 & 3.253 & 0 \\
\hline Los Alamos National Laboratory & 109 & 7.243 & 7.105 & 0 \\
\hline Oak Ridge National Laboratory & 1,049 & $1,387.7$ & 427.3 & 796.3 \\
\hline Pacific Northwest National Laboratory & 15 & 0.048 & 0.047 & 0 \\
\hline Rocky Flats Environmental Test Site & 5 & 0.004 & 0.004 & 0 \\
\hline Oak Ridge Y-12 Plant & $\underline{5}$ & 42.6 & 0.8 & 38.7 \\
\hline Totals & 1,505 & $1,800.7$ & 790.8 & 835.0 \\
\hline
\end{tabular}

${ }^{2}$ Based on Bereolos et al. June 1998. Excludes materials that are categorized as waste or SNF that may be candidate ${ }^{233} \mathrm{U}$ materials after recovery or separation.

bincludes cumulative contribution from 62 packaged items having $<0.1 \mathrm{~kg}$. 
Table A.2. Material-form code definitions

\begin{tabular}{|c|c|c|}
\hline Material type & Form & Code \\
\hline Weapon component & $\begin{array}{l}\text { Parts } \\
\text { Pits } \\
\text { Canned subassembly }\end{array}$ & $\begin{array}{l}\text { PA } \\
\text { PT } \\
\text { CS }\end{array}$ \\
\hline Metal & $\begin{array}{l}\text { Pure } \\
\text { Impure } \\
\text { Alloys }\end{array}$ & $\begin{array}{l}\text { MP } \\
\text { MI } \\
\text { MA }\end{array}$ \\
\hline Oxides & $\begin{array}{l}\text { Pure } \\
\text { Impure } \\
\text { Other (specify) }\end{array}$ & $\begin{array}{l}\text { PO } \\
\text { PI } \\
\text { OO }\end{array}$ \\
\hline Compounds & $\begin{array}{l}\text { Uranium hexafluoride } \\
\text { Other (specify) }\end{array}$ & $\begin{array}{l}\text { UF } \\
\text { UO }\end{array}$ \\
\hline Sources and samples & $\begin{array}{l}\text { Sealed } \\
\text { Other (specify) }\end{array}$ & $\begin{array}{l}\text { SS } \\
\text { SO }\end{array}$ \\
\hline Combustibles & $\begin{array}{l}\text { Graphite } \\
\text { Paper, plastics, wood, mop heads, etc. } \\
\text { Other (specify) }\end{array}$ & $\begin{array}{l}\mathrm{CG} \\
\mathrm{CP} \\
\mathrm{CO}\end{array}$ \\
\hline Noncombustibles & $\begin{array}{l}\text { Glass } \\
\text { Nonuranium metal } \\
\text { Other (specify) }\end{array}$ & $\begin{array}{l}\text { NG } \\
\text { NM } \\
\text { NO }\end{array}$ \\
\hline Process residues & $\begin{array}{l}\text { Reduction } \\
\text { Incinerator ash } \\
\text { Sludge } \\
\text { Filters } \\
\text { Other (specify) }\end{array}$ & $\begin{array}{l}\text { RR } \\
\text { IA } \\
\text { SR } \\
\text { RF } \\
\text { RO }\end{array}$ \\
\hline Solutions & $\begin{array}{l}\text { Nitric acid } \\
\text { Basic } \\
\text { Organic } \\
\text { Other (specify) }\end{array}$ & $\begin{array}{l}\text { SN } \\
\text { SC } \\
\text { OS } \\
\text { SZ }\end{array}$ \\
\hline Reactor fuel & $\begin{array}{l}\text { Unirradiated } \\
\text { Targets } \\
\text { Slightly irradiated } \\
\text { Other (specify) }\end{array}$ & $\begin{array}{l}\text { RU } \\
\text { RT } \\
\text { RS } \\
\text { RO }\end{array}$ \\
\hline Hold-up & Materials in pipes, tanks, ducts, equipment, etc. & HO \\
\hline
\end{tabular}

${ }^{a}$ When seal is broken, canned subassembly is called parts. 
Table A.3. Packaging types and codes

\begin{tabular}{|c|c|c|c|}
\hline General description & Packaging code & Subcode & Packaging details \\
\hline Cans & $\mathrm{C}$ & $\begin{array}{l}0 \\
1 \\
2 \\
3 \\
4\end{array}$ & $\begin{array}{l}\text { Food-pack/rim seal (tinned) } \\
\text { Food-pack/rim seal (stainless) } \\
\text { Slip lid } \\
\text { Screw lid } \\
\text { Other (specify) }\end{array}$ \\
\hline Plastic bagging & $\mathrm{B}$ & $\begin{array}{l}0 \\
1 \\
2 \\
3\end{array}$ & $\begin{array}{l}\text { Unknown } \\
\text { Polyethylene } \\
\text { Polyvinylchloride } \\
\text { Other (specify) }\end{array}$ \\
\hline Metal foil & $\mathrm{F}$ & $\begin{array}{l}0 \\
1 \\
2 \\
3\end{array}$ & $\begin{array}{l}\text { Unknown } \\
\text { Aluminum } \\
\text { Lead } \\
\text { Other (specify) }\end{array}$ \\
\hline Vessels & $\mathrm{V}$ & $\begin{array}{l}0 \\
1 \\
2 \\
3 \\
4 \\
5 \\
6 \\
7\end{array}$ & $\begin{array}{l}\text { Unknown } \\
\text { Welded } \\
\text { Knife-edge seal (i.e., Conflat( }) \\
\text { Elastomeric seal (O-ring) } \\
\text { Compression seal (Swagelockß etc.) } \\
\text { Screw lid } \\
\text { Gas cylinder }\left(\mathrm{UF}_{6} \text { ) }\right. \\
\text { Other (specify) }\end{array}$ \\
\hline Glass & G & $\begin{array}{l}0 \\
1 \\
2 \\
3\end{array}$ & $\begin{array}{l}\text { Other (specify) } \\
\text { Screw lid } \\
\text { Sealed vials/capsules } \\
\text { Glass-metal seal }\end{array}$ \\
\hline Plastic containers & $\mathrm{P}^{\mathrm{a}}$ & $\begin{array}{l}0 \\
1 \\
2 \\
3\end{array}$ & $\begin{array}{l}\text { Polyethylene/polypropylene-sealed } \\
\text { Polyethylene/polypropylene-unsealed } \\
\text { Polyethylene/polypropylene-unknown } \\
\text { Other (specify) }\end{array}$ \\
\hline Unknown & $\mathbf{U}$ & $\begin{array}{l}0 \\
1 \\
2 \\
3\end{array}$ & $\begin{array}{l}\text { Unknown } \\
\text { Suspected to be metal } \\
\text { Suspected to be plastic } \\
\text { Other (specify) }\end{array}$ \\
\hline Drums & $\mathrm{D}$ & $\begin{array}{l}1 \\
2 \\
3 \\
4\end{array}$ & $\begin{array}{l}55 \text {-gal } \\
30 \text {-gal } \\
<0 \text {-gal } \\
\text { Unspecified (add V if vented) }\end{array}$ \\
\hline Tanks & $\mathrm{T}$ & $\begin{array}{l}0 \\
1 \\
2 \\
3\end{array}$ & $\begin{array}{l}\text { Unknown } \\
\text { Raschig ring-filled } \\
\text { Geometrically favorable } \\
\text { Other (specify) }\end{array}$ \\
\hline
\end{tabular}


Table A.3. Packaging types and codes (continued)

\begin{tabular}{|c|c|c|c|}
\hline General description & Packaging code & Subcode & Packaging details \\
\hline Wooden crates or boxes & W & $\begin{array}{l}0 \\
1 \\
2 \\
3 \\
4\end{array}$ & $\begin{array}{l}\text { Metal burial box } \\
\text { Cardboard } \\
\text { Wooden } \\
\text { Fiberglass } \\
\text { Other (specify) }\end{array}$ \\
\hline Shipping containers and overpacks & $\mathrm{X}$ & $\begin{array}{l}0 \\
1 \\
2 \\
3\end{array}$ & $\begin{array}{l}\text { 5A overpack } \\
6 \mathrm{M} 110 \text {-gal } \\
\text { Other (specify) } \\
\text { Birdcage (storage only) }\end{array}$ \\
\hline
\end{tabular}

${ }^{a} \mathrm{P}=$ bottle. 
Table A.4. Nuclear material-type codes

\begin{tabular}{|c|c|c|c|c|c|}
\hline $\begin{array}{l}\text { Type } \\
\text { code }\end{array}$ & Type description & $\begin{array}{c}\text { Reporting } \\
\text { unit }\end{array}$ & $\begin{array}{l}\text { Type } \\
\text { code }\end{array}$ & Type description & $\begin{array}{c}\text { Reporting } \\
\text { unit }\end{array}$ \\
\hline \multicolumn{3}{|c|}{ Uranium-depleted in ${ }^{235} U$, wt $\%$} & 44 & ${ }^{241} \mathrm{Am}$ & g \\
\hline 10 & Total & $\mathrm{kg}$ & 45 & ${ }^{243} \mathrm{Am}$ & g \\
\hline 11 & $<0.21$ & $\mathrm{~kg}$ & 46 & Curium & g \\
\hline 12 & $0.21-<0.24$ & $\mathrm{~kg}$ & 47 & Berkelium & $\mu \mathrm{g}$ \\
\hline 13 & $0.24-<0.26$ & $\mathrm{~kg}$ & 48 & Californium & $\mu g$ \\
\hline 14 & $0.26-<0.28$ & $\mathrm{~kg}$ & & Plutonium & \\
\hline 15 & $0.28-<0.31$ & $\mathrm{~kg}$ & 50 & Total & $g$ \\
\hline 16 & $0.31-<0.50$ & $\mathrm{~kg}$ & & ${ }^{240} \mathrm{Pu}$ & \\
\hline 17 & $0.50-<0.60$ & $\mathrm{~kg}$ & 51 & $<4.00$ & $\mathrm{~g}$ \\
\hline 18 & $0.60-0.711$ & $\mathrm{~kg}$ & 52 & $4.00-<.00$ & g \\
\hline \multicolumn{3}{|c|}{ Uranitum-enriched in ${ }^{235} U, w t \%$} & 53 & $7.00-<10.00$ & $\mathbf{g}$ \\
\hline 20 & Total & $\mathrm{g}$ & 54 & $10.00-<13.00$ & g \\
\hline 21 & $>0.711-<0.90$ & g & 55 & $13.00-<16.00$ & $\mathrm{~g}$ \\
\hline 22 & $0.90-<1.15$ & $\mathrm{~g}$ & 56 & $16.00-<19.00$ & $g$ \\
\hline 23 & $1.15-<1.60$ & $\mathrm{~g}$ & 57 & 19.00 and above & $\mathrm{g}$ \\
\hline 24 & $1.60-<2.00$ & g & & Lithium-enriched in ${ }^{6} L i$ & $\mathrm{~kg}$ \\
\hline 25 & $2.00-<.60$ & g & 60 & Total & $\mathbf{k g}$ \\
\hline 26 & $2.60-2.90$ & $g$ & 61 & $>$ Normal to $<55.00$ & $\mathrm{~kg}$ \\
\hline 27 & $2.90-3.10$ & $\mathbf{g}$ & 62 & $55.00-<80.00$ & $\mathrm{~kg}$ \\
\hline 28 & $3.10-<3.40$ & $\mathrm{~g}$ & 63 & 80.00 and above & $\mathrm{kg}$ \\
\hline 29 & $3.40-<3.90$ & $\mathrm{~g}$ & & Uranium-enriched in ${ }^{233} U$ & \\
\hline 30 & $3.90-<4.10$ & $\mathrm{~g}$ & 70 & Total & $g$ \\
\hline 31 & $4.10-<5.00$ & $\mathbf{g}$ & 71 & $<5 \mathrm{ppm}^{232} \mathrm{U}$ & g \\
\hline 32 & $5.00-<10.00$ & $\mathrm{~g}$ & 72 & $5-<10 \mathrm{ppm}^{232} \mathrm{U}$ & $\mathrm{g}$ \\
\hline 33 & $10.00-20.00$ & $\mathrm{~g}$ & 73 & $10-<50 \mathrm{ppm} 232 \mathrm{U}$ & $\mathbf{g}$ \\
\hline 34 & $20.00-<35.00$ & $\mathrm{~g}$ & 74 & $50 \mathrm{ppm}$ and above ${ }^{232} \mathrm{U}$ & $\mathbf{g}$ \\
\hline 35 & $35.00-<45.00$ & g & 81 & Normal uranium $\left(0.711 \mathrm{wt} \%{ }^{235} \mathrm{U}\right)$ & $\mathbf{k g}$ \\
\hline 36 & $45.00-<80.00$ & $g$ & 82 & ${ }^{237} \mathrm{~Np}$ & $\mathrm{~g}$ \\
\hline
\end{tabular}


A-9

Table A.4. Nuclear material-type codes (continued)

\begin{tabular}{ccc|ccc}
\hline $\begin{array}{c}\text { Type } \\
\text { code }\end{array}$ & Type description & $\begin{array}{c}\text { Reporting } \\
\text { unit }\end{array}$ & $\begin{array}{c}\text { Type } \\
\text { code }\end{array}$ & \multicolumn{1}{c}{ Type description } & $\begin{array}{c}\text { Reporting } \\
\text { unit }\end{array}$ \\
\hline 37 & $80.00-<92.00$ & $\mathrm{~g}$ & 83 & $238 \mathrm{Pu}$ & $\mathrm{g}\left(1 \times 10^{-1}\right)$ \\
38 & $92.00-<94.00$ & $\mathrm{~g}$ & 86 & $\mathrm{D} 2$ & $\mathrm{~kg}\left(1 \times 10^{-1}\right)$ \\
39 & 94.00 and above & $\mathrm{g}$ & 87 & Tritium & $\mathrm{g}\left(1 \times 10^{-2}\right)$ \\
& $242 \mathrm{Pu}$ & $\mathrm{g}$ & 88 & Thorium & $\mathrm{kg}$ \\
40 & Total & $\mathrm{g}$ & $\mathrm{g}$ & Uranium in cascades & $\mathrm{g}$ \\
41 & $20-60$ & $\mathrm{~g}$ & & This series available for local use & \\
42 & $>60$ & & & & \\
\hline
\end{tabular}




\section{A-10}

Table A.5. ${ }^{233} \mathrm{U}$ material characteristics at INEEL-ICPP ${ }^{2}$

\begin{tabular}{|c|c|c|c|c|c|c|c|}
\hline \multirow[b]{2}{*}{$\begin{array}{l}\text { Material form } \\
\text { description }^{b}\end{array}$} & \multirow[b]{2}{*}{$\begin{array}{c}\text { Packaging } \\
\text { types }^{c}\end{array}$} & \multirow[b]{2}{*}{$\begin{array}{c}\text { No. of } \\
\text { packages }\end{array}$} & \multicolumn{2}{|c|}{ Material-type code ${ }^{\mathrm{d}, e}$} & \multirow[b]{2}{*}{$\begin{array}{c}\text { Total Uf } \\
\text { (kg) }\end{array}$} & \multirow[b]{2}{*}{$\begin{array}{c}{ }^{233} \mathrm{U}^{\mathrm{e}, \mathrm{f}} \\
(\mathrm{kg})\end{array}$} & \multirow[b]{2}{*}{$\begin{array}{l}{ }^{235} \mathrm{ve}^{e, f} \\
(\mathrm{~kg})\end{array}$} \\
\hline & & & ${ }^{233} \mathrm{U}$ & ${ }^{235} \mathrm{U}$ & & & \\
\hline $\mathrm{ROS}$ & $\mathrm{C} 4$ & 6 & 71 & & * & $*$ & 0 \\
\hline ROB & $\mathrm{C4}$ & 140 & 72 & & $*$ & $*$ & 0 \\
\hline ROS & $\mathrm{C4}$ & 1 & 73 & & $*$ & * & 0 \\
\hline$P O^{h}$ & $\mathrm{C} 3$ & 1 & 71 & & * & $*$ & 0 \\
\hline $\mathrm{PO}^{\mathrm{h}}$ & $\mathrm{C} 3$ & 1 & 71 & & * & * & 0 \\
\hline$S^{h}$ & P3 & 3 & 71 & & $*$ & $*$ & 0 \\
\hline $\mathrm{PO}^{\mathrm{h}}$ & $\mathrm{C} 4$ & 1 & 71 & & * & * & 0 \\
\hline$S N^{h}$ & P3 & 1 & 71 & & * & $*$ & 0 \\
\hline$R U^{h}$ & $\mathrm{Co}$ & 6 & 71 & & * & * & 0 \\
\hline $\mathrm{PO}^{h}$ & $\mathrm{~B} 1$ & 39 & 71 & 39 & * & $*$ & * \\
\hline $\mathrm{PO}^{\mathrm{h}}$ & $\mathrm{CO}$ & 1 & 72 & & * & * & 0 \\
\hline$R U^{i}$ & $x_{2}$ & 41 & 72 & & 323.5 & 317.4 & 0 \\
\hline $\mathrm{RU}^{\mathrm{ij}}$ & D1 & 68 & 73 & & 13.2 & 12.8 & 0 \\
\hline$R U^{i j}$ & $\mathrm{X} 1$ & 77 & 73 & & 21.9 & 21.4 & 0 \\
\hline $\mathrm{RO}^{\mathrm{k}}$ & $x_{2}$ & 47 & 74 & $34,36,37,38$ & 550.4 & 508.6 & 10.1 \\
\hline $\mathrm{RO}^{\mathrm{l}}$ & $x_{2}$ & 38 & 71 & & 10.5 & .8 & 0 \\
\hline $\mathbf{R O}^{1}$ & $\mathrm{x} 2$ & 634 & 72 & & 168.4 & 15.3 & 0 \\
\hline $\mathrm{RO}^{1}$ & $\mathrm{X}_{2}$ & 193 & 73 & & 36.5 & 5.8 & 0 \\
\hline $\mathrm{RO}^{\mathbf{l}}$ & $x 2$ & 737 & 74 & & 116.6 & 24.4 & 0 \\
\hline$R O^{m}$ & $\times 2$ & 84 & 71 & & 31.1 & 3.7 & 0 \\
\hline $\mathrm{RO}^{\mathrm{m}}$ & $\mathrm{x} 2$ & 78 & 72 & & 30.0 & 5.2 & 0 \\
\hline $\mathrm{RO}^{\mathrm{m}}$ & $\mathrm{x} 2$ & 376 & 73 & & 154.8 & 45.0 & 0 \\
\hline $\mathrm{RO}^{\mathrm{m}}$ & $\mathrm{x} 2$ & 206 & 74 & & 92.3 & 36.3 & 0 \\
\hline Totals $^{n}$ & $x 2$ & 186 & 72,73 & & 358.6 & 351.6 & 0 \\
\hline
\end{tabular}

${ }^{2}$ Based on Chemical Technology Division September 22, 1995; DOE Idaho Operations Office July 19. 1995; Liable August 1, 1996; and Bright November 12, 1996.

b Material-type and form codes listed in Table A.2.

'Packaging types and codes listed in Table A.3.

$\mathrm{d}_{\text {Nuclear material-type codes listed for }}{ }^{233} \mathrm{U}$ and ${ }^{235} \mathrm{U}$ in Table A.4.

EAccountable amounts only. See Table A4.

$f_{\text {An asterisk }}(*)$ is used to represent mass quantities of material $<0.1 \mathrm{~kg}$.

8 Scrap from Bettis Atomic Power Laboratory.

hiscellaneous lab materials.

iUnirradiated Shippingport LWBR fuel.

jLocated at INEEL RWMC.

$\mathrm{k}_{\text {Irradiated LWBR SNF. }}$

'Peach Bottom fuel (Core 1 and 2).

Fort St. Vrain Reactor fuel. 
A-11

Table A.6. Summary of ${ }^{233} \mathrm{U}$ material characteristics at $\mathrm{ORNL}^{\mathrm{a}}$

\begin{tabular}{|c|c|c|c|c|c|c|c|}
\hline \multirow[b]{2}{*}{$\begin{array}{c}\text { Material form } \\
\text { description }^{b}\end{array}$} & \multirow[b]{2}{*}{$\begin{array}{l}\text { Packaging } \\
\text { types }^{c}\end{array}$} & \multirow[b]{2}{*}{$\begin{array}{c}\text { No. of } \\
\text { packages }\end{array}$} & \multicolumn{2}{|c|}{ Material-type code ${ }^{\mathrm{d}, e}$} & \multirow[b]{2}{*}{$\begin{array}{c}\text { Total U } \\
\text { (kg) }\end{array}$} & \multirow[b]{2}{*}{$\begin{array}{c}{ }^{233} \mathrm{U}^{\mathrm{e}} \\
(\mathrm{kg})\end{array}$} & \multirow[b]{2}{*}{$\begin{array}{r}{ }^{235} \mathrm{U}^{\mathrm{e}} \\
(\mathrm{kg})\end{array}$} \\
\hline & & & ${ }^{233} \mathrm{U}$ & ${ }^{235} \mathrm{U}$ & & & \\
\hline Uranium metal and alloys & $\mathrm{C} 4^{\mathrm{f}}$ & 27 & $71-73$ & & 17.344 & 16.989 & 0 \\
\hline Salts (UO) & C3 & 4 & 74 & & 3.191 & 2.919 & 0 \\
\hline MSRE $\mathfrak{g}$ & $\mathrm{C} 4$ & 1 & 74 & & 0.189 & 0.159 & 0 \\
\hline \multirow[t]{6}{*}{ UOx powder (OO) } & $\mathrm{C}^{\mathrm{f}}$ & 44 & $71-73$ & & 8.150 & 7.984 & 0 \\
\hline & $\mathrm{C}$ & 22 & 71 & & 15.358 & 15.015 & 0 \\
\hline & $\mathrm{V} 1^{\mathrm{h}}$ & 128 & 72 & & 45.674 & 44.766 & 0 \\
\hline & $\mathrm{C} 3$ & 142 & 72 & & 96.453 & 91.153 & 0 \\
\hline & $\mathrm{C} 4^{\mathrm{f}}$ & 27 & 73 & & 11.143 & 10.720 & 0 \\
\hline & $\mathrm{C} 4^{\mathrm{i}}$ & 140 & 74 & & 67.371 & 61.569 & 0 \\
\hline \multirow[t]{2}{*}{$\mathrm{U}_{3} \mathrm{O}_{8}$ monolith $(\mathrm{OO})$} & $\mathrm{C}^{\mathrm{j}}$ & 27 & 73 & & 65.188 & 60.265 & 0 \\
\hline & $\mathrm{C} 4^{\mathrm{j}}$ & 403 & 74 & 36 & $1,042.585$ & 101.143 & 796.334 \\
\hline Mound $(P O)^{k}$ & $\mathrm{X} 1$ & 20 & $71-73$ & & 3.648 & 3.493 & 0 \\
\hline Miscellaneous (MP) $)^{l}$ & $\mathrm{C} 4^{\mathrm{f}}$ & 64 & 71,72 & & 11.415 & 11.166 & 0 \\
\hline Totals & $\mathrm{C} 3, \mathrm{C} 4, \mathrm{~V} 1, \mathrm{X} 1$ & 1,049 & $71-74$ & 36 & $1,387.709$ & 427.341 & 796.334 \\
\hline
\end{tabular}

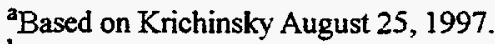

baterial-type and form codes listed in Table A.2.

'Packaging types and codes listed in Table A.3.

d Nuclear material-type codes listed for ${ }^{233} U$ and ${ }^{235} \mathrm{U}$ in Table A.4.

Accountable amounts only. See nuclcar material-type codes listed in Table A.4.

$f_{\text {Cans of various types. }}$

golten Salt Reactor Experiment.

${ }^{\text {h}}$ Stainless steel plates welded shut.

${ }^{i}$ Welded aluminum cans.

jStainless steel cans welded shut.

kMaterial (Uox powder) shipped from the Mound Plant in 1996.

${ }^{1}$ Uranium in irregular forms. 
Table A.7. Exception-case material: unirradiated LWBR fuel characteristics ${ }^{\mathrm{a}}$

\begin{tabular}{|c|c|c|c|c|c|c|c|c|c|}
\hline \multirow[b]{2}{*}{ Rod type } & \multirow[b]{2}{*}{$\begin{array}{c}\text { Number } \\
\text { of rods }\end{array}$} & \multicolumn{2}{|c|}{${ }^{233} \mathrm{U}$ in fuel } & \multicolumn{3}{|c|}{ Rod dimensions, in. } & \multicolumn{3}{|c|}{ Rod masses, kg } \\
\hline & & wt $\%$ & $\mathrm{~kg}$ & $\begin{array}{c}\text { Outer } \\
\text { diameter }\end{array}$ & Length & $\begin{array}{c}\text { Clad } \\
\text { thickness }\end{array}$ & $\begin{array}{l}\text { cladding } \\
\text { hardware }\end{array}$ & Fuel & Total \\
\hline \multicolumn{10}{|l|}{ Core and criticality experiments } \\
\hline Seed & 2,290 & $4.3-5.2$ & 55.70 & 0.306 & $101.1-119.1$ & 0.027 & 0.29 & 0.84 & 1.14 \\
\hline Standard blanket & 1,667 & $1.0-2.0$ & 55.52 & 0.572 & $104.9-122.1$ & $0.028-122.1$ & 0.83 & 3.38 & 4.21 \\
\hline Power-flattening blanket & 1,630 & $1.6-2.7$ & 82.16 & 0.528 & $104.9-122.2$ & $104.9-122.2$ & 0.71 & 2.85 & 3.56 \\
\hline BMU seed & 6,896 & $2.5-12.0$ & 57.05 & 0.25 & 28.2 & 0.019 & 0.041 & 0.335 & 0.376 \\
\hline BMU blanket & 1,759 & 2.0 & 40.97 & 0.624 & 42.5 & 0.0305 & 0.307 & $1.911-2.824$ & $2.218-3.131$ \\
\hline Scrap pellets & $N A^{b}$ & 2.0 & 7.5 & & & & & & \\
\hline Retainer pellets and rods & $\mathfrak{c}$ & 1.3 & 3.5 & & & & & & \\
\hline Totals & 14,242 & & 302.4 & & & & & & \\
\hline
\end{tabular}

${ }^{a}$ As reported in Bolton, Christensen, and Hallinan March 1989.

b These pellets are stored in stainless steel tubes inside a canister.

${ }^{c}$ Uncertain. 
Table A.8. Exception-case materials: type, number features, and total number of canisters required for unirradiated LWBR storage containers ${ }^{\mathrm{a}}$

\begin{tabular}{|c|c|c|c|c|c|c|}
\hline \multirow[b]{2}{*}{ Rod type } & \multirow[b]{2}{*}{$\begin{array}{l}\text { Total number } \\
\text { of rods }\end{array}$} & \multicolumn{4}{|c|}{ Features } & \multirow[b]{2}{*}{$\begin{array}{l}\text { Total number of } \\
\text { canisters required }\end{array}$} \\
\hline & & $\begin{array}{l}\text { Number of } 1 / 4 \text {-in. } \\
\text { OD aluminum } \\
\text { rods to fill }\end{array}$ & Number of rods & $\begin{array}{c}{ }^{233} \mathrm{U} \text { content } \\
(\mathrm{kg})\end{array}$ & $\begin{array}{c}\text { Total mass } \\
(\mathbf{k g})\end{array}$ & \\
\hline \multicolumn{7}{|l|}{ Core and criticality experiments } \\
\hline Seed & 2,290 & 56 & 458 & 11.14 & 781 & 5 \\
\hline Standard blanket & 1,667 & 18 & 140 & 4.63 & 827 & 12 \\
\hline Power-flattening blanket & 1,630 & 19 & 163 & 8.22 & $824^{b}$ & 10 \\
\hline BMU seed & 6,896 & 51 & 575 & $9.20^{\mathrm{c}}$ & $974-1,108^{d}$ & 12 \\
\hline BMU blanket & 1,759 & 328 & 147 & & & \\
\hline Scrap pellets & $\mathrm{NA}^{\mathrm{e}}$ & NA & & 7.5 & 604 & $1^{f}$ \\
\hline Retainer pellets and rods & g & NA & & 7.5 & 671 & $1^{\mathrm{f}}$ \\
\hline Total & 14,242 & & & & & 40 \\
\hline
\end{tabular}

${ }^{a}$ As reported in Bolten, Christense, and Hallinan March 1989

bIncludes $223 \mathrm{~kg}$ for the storage canister itself.

${ }^{\mathrm{c}}$ Assumes two BMU blanket canisters and one BMU seed canister containing $12 \mathrm{wt} \%{ }^{233} \mathrm{U}$ per unirradiated fuel storage canister, which produces the highest uranium content for the canisters containing the BMU rods, although other storage canisters containing one BMU blanket canister and two BMU seed canisters with 2 to 5 wt \% ${ }^{233} \mathrm{U}$ were also shipped.

${ }^{\mathrm{d}}$ Includes $223 \mathrm{~kg}, 29 \mathrm{~kg}$, and $79 \mathrm{~kg}$ for storage canister, one BMU seed canister, and two BMU blanket canisters, respectively.

${ }^{\text {e }}$ These pellets are stored in stainless steel tubes inside the canister.

These are the same canister.

BUncertain. 
A-14

Table A.9. Current characteristics of DOE site CH TRUW (mixed and nonmixed) ${ }^{\mathrm{a}}$

\begin{tabular}{|c|c|c|c|c|c|c|c|}
\hline \multirow[b]{2}{*}{ Site } & \multicolumn{2}{|c|}{$\begin{array}{c}\text { Volume } \\
\left(\mathbf{m}^{3}\right)\end{array}$} & \multirow{2}{*}{$\begin{array}{c}\text { Total waste } \\
\text { mass }^{\mathrm{b}} \\
\text { (g) }\end{array}$} & \multicolumn{4}{|c|}{$\begin{array}{c}\text { Breakdown of mass by fissile nuclide } \\
\text { (g) }\end{array}$} \\
\hline & As-generated & $\begin{array}{l}\text { Final } \\
\text { form }\end{array}$ & & ${ }^{233} \mathrm{U}$ & ${ }^{235} \mathbf{U}$ & ${ }^{239} \mathrm{Pu}$ & ${ }^{241} \mathrm{Pu}$ \\
\hline ANL-E & 80.6 & 80.6 & $50,000,000$ & & & & 1 \\
\hline$A N L-W$ & 7.0 & 7.0 & $3,560,000$ & & & & \\
\hline ARCO & $<0.1$ & 0.2 & 107,000 & c & c & c & 4 \\
\hline ETEC & 1.7 & 1.7 & 856,000 & c & c & 1 & c \\
\hline Hanford & $11,008.0$ & $11,007.8$ & $5,620,000,000$ & 8,290 & 161,000 & 446,000 & 891 \\
\hline INEEL & $64,760.2$ & $35,979.7$ & $45,600,000,000$ & 93,200 & 28,800 & 647,000 & 1,340 \\
\hline KAPL & 0.0 & 23.9 & $12,200,000$ & & & & \\
\hline LANL & $8,610.1$ & $8,610.1$ & $5,350,000,000$ & 4,390 & 40,800 & 559,000 & 944 \\
\hline LBNL & 0.9 & 0.9 & 443,000 & c & c & c & c \\
\hline LLNL & 239.6 & 238.6 & $102,000,000$ & c & 295 & 2,910 & 17 \\
\hline MOUND & 235.8 & 235.8 & $150,000,000$ & c & c & 481 & \\
\hline MURR & 0.2 & 0.2 & 107,000 & c & c & c & \\
\hline NTS & 618.2 & 618.2 & $315,000,000$ & 154 & 26 & 41,800 & 2 \\
\hline ORNL & 921.1 & 460.6 & $235,000,000$ & 10,200 & 2,900 & 15,100 & 444 \\
\hline PAD & 4.1 & 4.1 & $4,500,000$ & c & c & 3 & \\
\hline PANT & 0.6 & 0.6 & 318,000 & & c & 1 & \\
\hline RFETS & $1,889.2$ & $6,060.5$ & $4,640,000,000$ & c & 836 & $3,150,000$ & 7,216 \\
\hline SNLNM & 8.2 & 8.2 & $4,190,000$ & c & c & 64 & \\
\hline SRS & $6,033.5$ & $2,220.3$ & $1,470,000,000$ & c & 1,060 & 133,000 & 471 \\
\hline TBE & 0.2 & 0.2 & 324,000 & & & & \\
\hline USAMC & 2.5 & 2.5 & $1,270,000$ & & & 290 & \\
\hline WVDP & 37.4 & 37.4 & $23.200,000$ & & $\ldots$ & {[} & $<1$ \\
\hline Totals $^{\mathbf{d}}$ & $94,459.1$ & $65,600.1$ & $63,583,075,000$ & 116,234 & 235,717 & $4,995,650$ & 11,330 \\
\hline
\end{tabular}

${ }^{2}$ Based on Harvill March 2, 1998, and DOE December 1997.

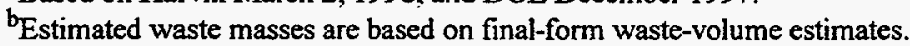

'Trace amount (much $<1 \mathrm{~g}$ ).

dTo be repackaged: $73,604 \mathrm{~m}^{3}(78 \%)$ of as-generated waste and $44,745 \mathrm{~m}^{3}(68 \%)$ of final-form waste. 
A-15

Table A.10. Current characteristics of DOE site RH TRUW (mixed and nonmixed) ${ }^{\mathrm{a}}$

\begin{tabular}{|c|c|c|c|c|c|c|c|}
\hline \multirow[b]{2}{*}{ Site } & \multicolumn{2}{|c|}{$\begin{array}{c}\text { Volume } \\
\left(\mathbf{m}^{3}\right)\end{array}$} & \multirow{2}{*}{$\begin{array}{c}\text { Total waste } \\
\text { mass }^{\mathbf{b}} \\
\text { (g) }\end{array}$} & \multicolumn{4}{|c|}{$\begin{array}{l}\text { Breakdown of mass by fissile nuclide } \\
\text { (g) }\end{array}$} \\
\hline & As-generated & Final form & & ${ }^{233} \mathrm{U}$ & ${ }^{235} \mathrm{U}$ & ${ }^{239} \mathrm{Pu}$ & ${ }^{241} \mathrm{Pu}$ \\
\hline ANL-W & 22.1 & 22.1 & $10,400,000$ & & & & \\
\hline ETEC & 5.4 & 5.4 & $2,970,000$ & & $\mathrm{c}$ & 10 & c \\
\hline Hanford & 203.0 & 203.0 & $108,000,000$ & 47 & 59,900 & 6,610 & 73 \\
\hline INEEL & 62.0 & 159.6 & $95,500,000$ & 25 & 2,360 & 498 & 1 \\
\hline KAPL & 3.1 & 0.0 & 0 & & $\mathrm{c}$ & c & $\mathbf{c}$ \\
\hline LANL & 93.2 & 93.2 & $49,500,000$ & & 3,840 & 3,970 & 1 \\
\hline NTS & 0.0 & 0.0 & 0 & & $\mathrm{c}$ & 38 & c \\
\hline ORNL & $1,283.0$ & $1,385.4$ & $1,020,000,000$ & 3,080 & 8,080 & 427 & $<1$ \\
\hline SNL/NM & 0.0 & 0.0 & 0 & & c & c & \\
\hline SRS & 0.6 & 0.9 & 473,000 & & 1 & $\mathbf{c}$ & \\
\hline WVDP & 483.6 & 483.6 & $231,000,000$ & & & & \\
\hline Total $^{d}$ & $2,156.0$ & $2,353.2$ & $1,517,843,000$ & 3,152 & 74,181 & 11,553 & 75 \\
\hline
\end{tabular}

${ }^{a}$ Based on Harvill March 2, 1998, and DOE December 1997.

${ }^{b}$ Estimated waste masses are based on final-form waste-volume estimates.

${ }^{c}$ Trace amount (much $<1 \mathrm{~g}$ ).

${ }^{\mathrm{d}}$ To be repackaged: $1,349 \mathrm{~m}^{3}(63 \%)$ of as-generated waste and $1,546 \mathrm{~m}^{3}(66 \%)$ of final-form waste. 
Table A.11. Isotopic breakdown of uranium mass (g) in DOE site CH TRUW ${ }^{\mathrm{a}}$

\begin{tabular}{|c|c|c|c|c|c|c|}
\hline Site & ${ }^{232} U$ & ${ }^{233} \mathrm{U}$ & ${ }^{235} U$ & ${ }^{238} U$ & Other $^{b}$ & Total U \\
\hline ANL-E & & & & & & 0 \\
\hline ANL-W & & & & & & 0 \\
\hline ARCO & & c & c & c & $\mathrm{c}$ & $<1$ \\
\hline ETEC & & c & c & c & c & c \\
\hline Hanford & & 8,290 & 161,000 & $14,300,000$ & 8,000 & $14,477,290$ \\
\hline INEEL & 1.13 & 93,200 & 28,800 & 344,000 & 1,106 & 467,107 \\
\hline KAPL & & & & & & 0 \\
\hline LANL & $3.27 \mathrm{E}-19$ & 4,390 & 40,800 & $3,090,000$ & 1,203 & $3,136,393$ \\
\hline LBNL & & c & c & c & c & $<1$ \\
\hline LLNL & & c & 295 & 96,700 & 1 & 96,996 \\
\hline Mound & & & c & & 9 & 9 \\
\hline MURR & & c & c & $<1$ & c & $<1$ \\
\hline NTS & $7.28 \mathrm{E}-4$ & 154 & 26 & 488 & 2 & 670 \\
\hline ORNL & $1.29 \mathrm{E}-2$ & 10,200 & 2,900 & 129,000 & 2,686 & 144,786 \\
\hline PAD & & c & c & & & c \\
\hline PANT & & & c & & & c \\
\hline RFETS & & c & 107 & c & 241 & 348 \\
\hline SNL/NM & & c & c & & c & c \\
\hline SRS & & c & 1,060 & 2,730 & 3,926 & 7,716 \\
\hline TBE & & & & & & 0 \\
\hline USAMC & & & & & & 0 \\
\hline WVDP & 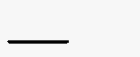 & & - & {[} & - & 0 \\
\hline Totals & 1.14 & 116,234 & 234,988 & $17,962,918$ & 17,174 & $18,331,315$ \\
\hline
\end{tabular}

${ }^{2}$ Based on Harvill March 2, 1998, and DOE December 1997.

${ }^{\mathrm{b}}$ Includes contributions (if any) from ${ }^{234} \mathrm{U},{ }^{236} \mathrm{U}$, and ${ }^{237} \mathrm{U}$.

${ }^{c}$ Trace amount (much $<1 \mathrm{~g}$ ). 


\section{A-17}

Table A.12. Isotopic breakdown of uranium mass (g) in DOE site RH TRUW

\begin{tabular}{|c|c|c|c|c|c|c|}
\hline Site & ${ }^{232} \mathrm{U}$ & ${ }^{233} \mathrm{U}$ & ${ }^{235} U$ & ${ }^{238} \mathbf{U}$ & Other ${ }^{b}$ & Total U \\
\hline ANL-W & & & & & & 0 \\
\hline ETEC & & c & c & c & c & c \\
\hline Hanford & & 47 & 59,900 & 34,200 & 209 & 94,356 \\
\hline INEEL & & 25 & 2,360 & 4,010 & $<1$ & 6,395 \\
\hline KAPL & & c & c & c & c & c \\
\hline LANL & & c & 3,840 & 7 & $<1$ & 3,847 \\
\hline NTS & & $\mathfrak{c}$ & c & c & c & c \\
\hline ORNL & $9.71 \mathrm{E}-02$ & 3,080 & 8,080 & $3,100,000$ & 788 & $3,111,948$ \\
\hline SNL/NM & & c & c & & c & c \\
\hline SRS & & c & 1 & & $\mathrm{c}$ & 1 \\
\hline WVDP & - & $\mathrm{c}$ & & _ & - & $\mathrm{c}$ \\
\hline Total & $9.71 \mathrm{E}-02$ & 3,152 & 74,181 & $3,138,217$ & 998 & $3,216,547$ \\
\hline
\end{tabular}

aBased on Harville March 2, 1998, and DOE December 1997.

${ }^{b}$ Includes contributions (if any) from ${ }^{234} \mathrm{U},{ }^{236} \mathrm{U}$, and ${ }^{237} \mathrm{U}$.

${ }^{\mathrm{c}}$ Trace amount (much $\left.<1 \mathrm{~g}\right)$. 
Table A.13. Summary of ${ }^{233} \mathrm{U}$ concentration and mass content in 55 -gal drums at DOE sites ${ }^{\mathrm{a}}$

\begin{tabular}{|c|c|c|c|c|c|c|c|c|c|c|}
\hline \multirow[b]{2}{*}{$\begin{array}{c}{ }^{233} \mathrm{U} \text { concentration, } \mathrm{x} \\
(\mathrm{g} / \text { drum })\end{array}$} & \multicolumn{2}{|c|}{ Hanford } & \multicolumn{2}{|c|}{ INEEL } & \multicolumn{2}{|c|}{ LANL } & \multicolumn{2}{|c|}{ ORNL } & \multicolumn{2}{|c|}{ Total } \\
\hline & $\begin{array}{c}\text { No. of } \\
\text { drums }\end{array}$ & $\begin{array}{c}{ }^{233} \mathrm{U} \text { content } \\
\text { (g) }\end{array}$ & $\begin{array}{c}\text { No. of } \\
\text { drums }\end{array}$ & $\begin{array}{c}{ }^{233} \mathrm{U} \text { content } \\
(\mathrm{g})\end{array}$ & $\begin{array}{c}\text { No of } \\
\text { drums }\end{array}$ & $\begin{array}{l}{ }^{233} \mathrm{U} \text { content } \\
\text { (g) }\end{array}$ & $\begin{array}{c}\text { No. of } \\
\text { drums }\end{array}$ & $\begin{array}{c}{ }^{233} \mathrm{U} \text { content } \\
(\mathrm{g})\end{array}$ & $\begin{array}{l}\text { No. of } \\
\text { drums }\end{array}$ & $\begin{array}{c}{ }^{233} \mathrm{U} \text { content } \\
\text { (g) }\end{array}$ \\
\hline$x \leq 4$ & $\mathbf{0}$ & 0 & 698 & 723 & 12 & 5 & 157 & 333 & 867 & 1,061 \\
\hline $4<x \leq 50$ & 0 & 0 & 601 & 13,515 & 2 & 48 & 328 & 7,346 & 931 & 20,909 \\
\hline $50<x \leq 200$ & 44 & 6,827 & 463 & 50,782 & 14 & 1,334 & 29 & 2,707 & 550 & 61,650 \\
\hline$x>200$ & $\underline{2}$ & 440 & 107 & $\underline{29.019}$ & 9 & 2.916 & $\underline{2}$ & 438 & 120 & 32,813 \\
\hline Total & 46 & 7,267 & 1,869 & 94,039 & 37 & 4,303 & 516 & 10,824 & 2,468 & 116,433 \\
\hline
\end{tabular}

aBased on Drez April 3, 1998; Nielsen April 3, 1998; Hammond March 13, 1998; and Yong May 6, 1998.

${ }^{b}$ Hanford actually reports a total of 38 drums but eight of these have 110-gal capacity. For this study, it is assumed that wastes in a 110-gal drum are repackaged evenly into two 55-gal drums.

${ }^{c}$ All INEEL drums having ${ }^{233} \mathrm{U}$ are assumed to have 55 -gal capacity.

${ }^{d}$ LANL ${ }^{233} \mathrm{U}$ wastes in 30 -gal drums are assumed to be repackaged into 55 -gal drums. Some ${ }^{233} \mathrm{U}$ wastes are in crates, which are assumed to have the same capacity as 55 -gal drums.

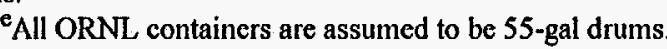


Table A.14. ${ }^{233} \mathrm{U}$ concentration and mass content in 55-gal drums at ORNL

\begin{tabular}{|c|c|c|c|c|c|c|}
\hline \multirow[b]{2}{*}{$\begin{array}{c}{ }^{233} \mathrm{U} \text { concentration, } \mathrm{x} \\
\text { (g/drum) }\end{array}$} & \multicolumn{2}{|c|}{ Total $\left.\right|^{\mathbf{a}}$} & \multicolumn{2}{|c|}{ With plutonium ${ }^{\mathrm{b}}$} & \multicolumn{2}{|c|}{ Without plutonium ${ }^{c}$} \\
\hline & $\begin{array}{l}\text { No. of } \\
\text { drums }\end{array}$ & $\begin{array}{c}{ }^{233} \mathrm{U} \text { content } \\
(\mathrm{g})\end{array}$ & $\begin{array}{l}\text { No. of } \\
\text { drums }\end{array}$ & $\begin{array}{c}{ }^{233} \mathrm{U} \text { content } \\
(\mathrm{g})\end{array}$ & $\begin{array}{l}\text { No of } \\
\text { drums }\end{array}$ & $\begin{array}{l}{ }^{233} \mathrm{U} \text { content } \\
\text { (g) }\end{array}$ \\
\hline$x \leq 4$ & 5,210 & 639 & 3,322 & 586 & 157 & 333 \\
\hline $4<x \leq 50$ & 349 & 7,651 & 347 & 7,628 & 328 & 7,346 \\
\hline $50<x \leq 200$ & 37 & 3,277 & 37 & 3,277 & 29 & 2,707 \\
\hline$x>200$ & 2 & 438 & $\underline{2}$ & 438 & $\underline{2}$ & 438 \\
\hline Total & 5,598 & 12,005 & 3,708 & 11,929 & 516 & 10,824 \\
\hline
\end{tabular}

${ }^{a}$ Based on Yong March 24, 1998. Includes contributions from drums containing TRUW, mixed TRUW, LLW, and MLLW,

${ }^{b}$ Based on Yong May 6, 1998. Includes those containers whose combined concentrations of ${ }^{233} \mathrm{U}$ and Pu exceed $100 \mathrm{nCi} / \mathrm{g}$.

${ }^{6}$ Based on Yong May 6, 1998. Includes those containers without any plutonium but having concentrations of ${ }^{233} \mathrm{U}$ that exceed $100 \mathrm{nCi} / \mathrm{g}$. 


\section{A.2 REFERENCES}

Bereolos, P. J. et al., June 1998. Strategy for Future Use and Disposition of U-233: History, Inventories, Storage Facilities, and Potential Future Uses, ORNL/TM-13551, Oak Ridge National Laboratory, Oak Ridge, Tennessee.

Bolton, S. R., A. B. Christensen, and E. J. Hallinan, March 1989. Final Safety Analysis Report: Storage of Unirradiated and Irradiated Light-Water Breeder Reactor Fuel in Underground Dry Wells at ICPP, INEL-WIN-107-4.7A, Rev. 1, Idaho Falls, Idaho.

Bright, Darris, November 12, 1996. "U-233 Review Team Presentation of U-233 Storage at RWMC," presentation to the Defense Nuclear Facilities Safety Board, Lockheed Martin Idaho Technologies, Idaho Falls, Idaho.

Chemical Technology Division, September 22, 1995. Inventory of ${ }^{233} U$ in the United States, Advanced Integrated Management Services, Inc., Oak Ridge National Laboratory, Oak Ridge, Tennessee.

Coony, F. M., April 3, 1998. Rust Federal Services of Hanford, Inc., Richland, Washington, correspondence to Stephen N. Storch, Oak Ridge National Laboratory, Oak Ridge, Tennessee.

Drez, P. E., April 3, 1998. Drez Environmental Associates, Albuquerque, New Mexico, correspondence to Stephen N. Storch, Oak Ridge National Laboratory, Oak Ridge, Tennessee.

Hammond, D. A., March 13, 1998. Lockheed Martin Idaho Technologies Company, Idaho National Engineering and Environmental Laboratory, Idaho Falls, Idaho, correspondence to Charles W. Forsberg, Lockheed Martin Energy Research Corp., Oak Ridge National Laboratory, Oak Ridge, Tennessee.

Harvill, J., March 2, 1998. Carlsbad Technical Assistance Contractor, National TRU Program, Carlsbad, New Mexico, correspondence to Stephen N. Storch, Oak Ridge National Laboratory, Oak Ridge, Tennessee.

Krichinshy, Alan M., August 25, 1997. Radiochemical Development Facility, Oak Ridge National Laboratory, Oak Ridge, Tennessee, correspondence to Stephen N. Storch, Oak Ridge National Laboratory, Oak Ridge, Tennessee.

Liable, E., August 1, 1996. Lockheed Martin Idaho Technologies Company, Idaho Falls, Idaho, correspondence to Stephen N. Storch, Oak Ridge National Laboratory, Oak Ridge, Tennessee.

Nielsen, J., April 3, 1998. Los Alamos National Laboratory, Los Alamos, New Mexico, correspondence to Stephen N. Storch, Oak Ridge National Laboratory, Oak Ridge, Tennessee.

U.S. Department of Energy, Idaho Operations Office, July 19, 1995. Materials-In-Inventory Lithium, Plutonium, and Other NMMSS-Tracked Materials Team Study of NMMSS-Tracked Materials at the Idaho National Engineering Laboratory (NEL) - July 19, 1995, OPE/OMI-95-062, Idaho Falls, Idaho. 
U.S. Department of Energy, December 1997. Integrated Data Base Report-1996: U.S. Spent Nuclear Fuel and Radioactive Waste Inventories, Projections, and Characteristics, DOE/RW-0006, Rev. 13, Oak Ridge National Laboratory, Oak Ridge, Tennessee.

Yong, L., March 24, 1998. Advanced Integrated Management Services, Inc., Oak Ridge, Tennessee, correspondence to Stephen N. Storch, Oak Ridge National Laboratory, Oak Ridge, Tennessee.

Yong, L., May 6, 1998. Advanced Integrated Management Services, Inc., Oak Ridge, Tennessee, correspondence to Stephen N. Storch, Oak Ridge National Laboratory, Oak Ridge, Tennessee. 


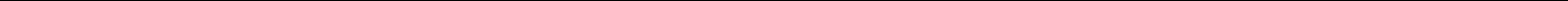


Appendix B:

EQUIVALENCE OF ${ }^{233} U_{\text {AND }}{ }^{235} U$ 


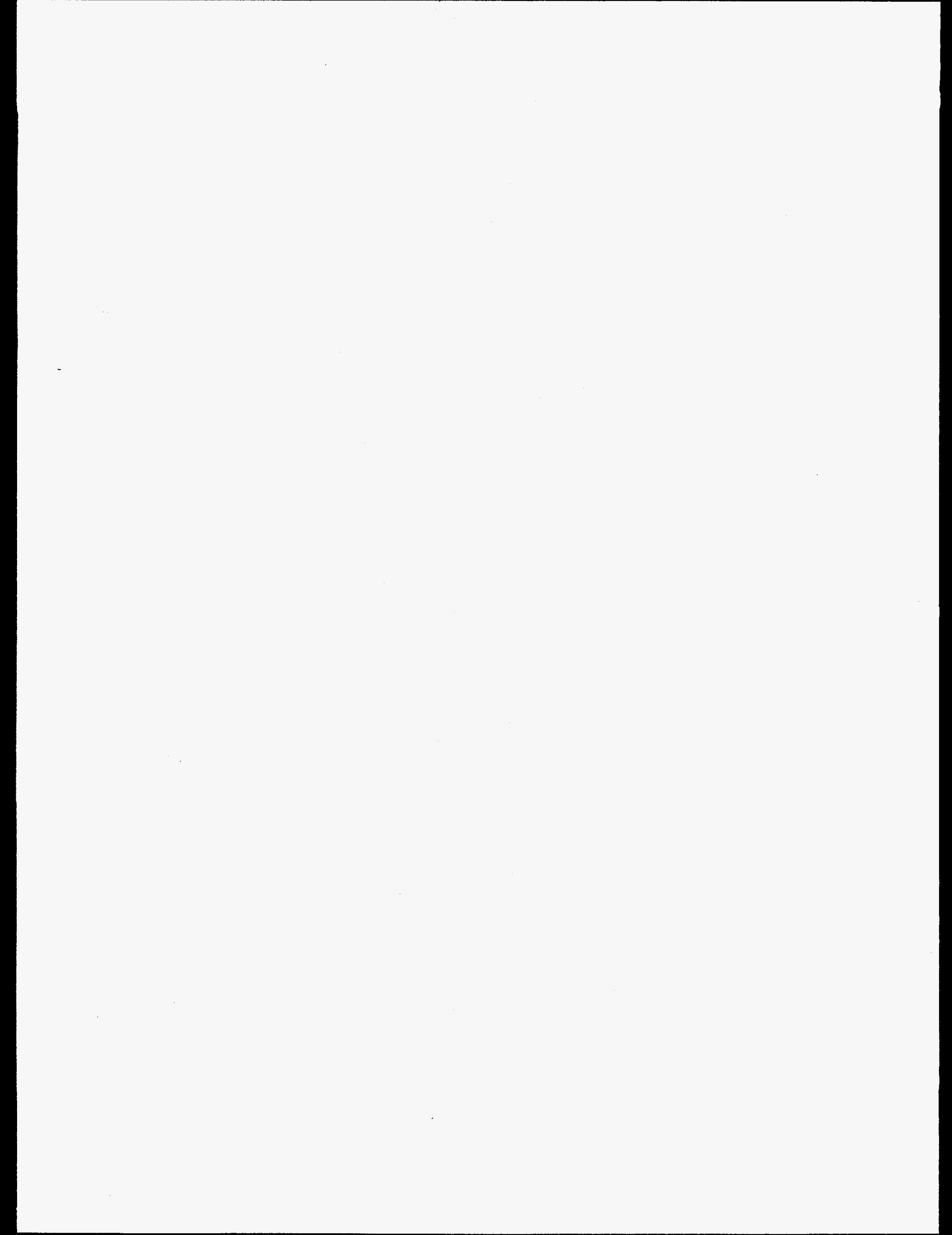




\section{Appendix B: EQUIVALENCE OF ${ }^{233} \mathrm{UAND}^{235} U$}

\section{B.1 DISCUSSION}

Criticality safety strategies, safeguards requirements, and arms control agreements were historically developed for enriched uranium and weapons-grade plutonium. Uranium-233 was often not considered because large-scale uses of ${ }^{233} \mathrm{U}$ were never implemented. The institutional structures and technical knowledge developed for enriched uranium and weapons-grade plutonium can be applied to ${ }^{233} \mathrm{U}$-provided that the differences in nuclear properties between ${ }^{233} \mathrm{U}$ and these other materials are accounted for.

A series of reports address the differences between ${ }^{235} \mathrm{U}$, plutonium, and ${ }^{233} \mathrm{U}$. The report by Elam, Forsberg, Hopper, and Wright (November 1997) defines the required isotopic dilution of ${ }^{233} \mathrm{U}$ with ${ }^{238} \mathrm{U}$ to minimize repository criticality issues. The report by Forsberg, Hopper, Richter, and Vantine (March 1998) defines the required isotopic dilution of ${ }^{233} U$ with ${ }^{238} U$ to convert weapons-usable material into nonweapons-usable ${ }^{233} \mathrm{U}$. The attachment to this appendix provides additional information on the equivalence of different enrichments of ${ }^{233} \mathrm{U}$ compared to enriched ${ }^{235} \mathrm{U}$. In each case, the comparisons allow development of management strategies for ${ }^{233} \mathrm{U}$ that take advantage of knowledge about enriched ${ }^{235} \mathrm{U}$.

\section{B.2 REFERENCES}

Elam, K. R., C. W. Forsberg, C. M. Hopper, and R. Q. Wright, November 1997. Isotopic Dilution Requirements for ${ }^{233} U$ Criticality Safety in Processing and Disposal Facilities, ORNL/TM-13524, Oak Ridge National Laboratory, Oak Ridge, Tennessee.

Forsberg, C. W., C. M. Hopper, J. L. Richter, and H. C. Vantine, March 1998. Definition of WeaponsUsable Uranium-233, ORNL/TM-13517, Oak Ridge National Laboratory, Oak Ridge, Tennessee. 
OAK RIDGE NATIONAL LABORATORY

MANAGED BY LOCKHEED MARTIN ENERGY RESEARCH CORPORATION

FOR THE U.S. DEPARTMENT OF ENERGY

Building 6011 . Rm-219, MS-6370

POST OFFICE $60 \times 2008$

OAK RIOGE. TN $37931-6370$
PHONE: (423) 576-8617

FAX: (423) 576-3513

INTERNET: hoppercm oomi.gov

Date: March 17, 1998

To: Charles W. Forsberg

c: $\quad$ C. V. Parks

L. M. Petrie

R. M. Westfall

R.Q. Wright

From: C. M. Hopper, 6011, MS-6370, 6-8617(RC)

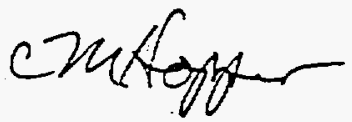

Subject: Wt \% ${ }^{233} \mathrm{U}$ Equivalence with 1.3, 1.5 and 5.0 Wt \% ${ }^{235} \mathrm{U}$ Enriched Uranium

Attached you will please find the March 17, 1998 memo from R. Q. Wright to C. M. Hopper entitled XSDRN 238-group $k$-inf Calculations for Uranium-Water Systems. As you will notice, the infinite neutron multiplication factor, $\mathrm{k}_{\mathrm{in}}$, was the selected parameter of equivalence between optimumly water moderated ${ }^{233} U$ diluted with depleted uranium (DU) (i.e., 0.2 wt \% ${ }^{235} \mathrm{U}$ and $0.998 \mathrm{wt} \%{ }^{238} \mathrm{U}$ ), and various enrichments of ${ }^{235} \mathrm{U}$ in uranium as optimumly water moderated. The specific equivalence value of $k_{\text {inf }}$ that was chosen for the optimumly water moderated ${ }^{233} \mathrm{U}$ systems was about $95 \%$ of the $k_{\text {iff }}$ for the various optimumly water moderated ${ }^{235} \mathrm{U}$ in uranium systems. The optimumly water moderated weight percent of ${ }^{233} \mathrm{U}$ in DU was also evaluated for infinite media systems comprised of various volume fractions (VF) of $\mathrm{SiO}_{2}$. Interpreted results from the attachment are tabulated below for ready reference.

\begin{tabular}{|c|c|c|c|c|c|c|c|}
\hline \multirow{2}{*}{$\begin{array}{l}\text { Wt\% }{ }^{235} \mathrm{U} \\
\text { in } \\
\text { Enriched } \\
\text { Uranium }\end{array}$} & \multirow{2}{*}{$\begin{array}{l}\text { Optimumly } \\
\text { Water } \\
\text { Moderated } \\
k_{\text {inf }}\end{array}$} & \multirow[t]{2}{*}{$\begin{array}{l}\text { Reference } \\
\mathrm{k}_{\mathrm{inf}} \text { for }{ }^{233} \mathrm{U} \\
\text { Systems }\end{array}$} & \multicolumn{5}{|c|}{$\begin{array}{l}\text { Weight Percent }{ }^{23} \cdot \mathrm{U} \text { in DU for Optimumly Water Moderated Systems comprised of } \\
\text { Uranium - Water and Various Volume Fractions }(\mathrm{VF}) \text { of } \mathrm{SiO}_{2} \text { to yield } \mathrm{k}_{\text {irr }}-95 \% \text { of } \\
\text { the Optimumly Water Moderated Enriched Uranium } \mathrm{k}_{\text {ins }}\end{array}$} \\
\hline & & & $V F=0.0$ & $\mathrm{VF}=0.3$ & $\mathrm{VF}=0.4$ & $\mathrm{VF}=0.5$ & $V F=0.6$ \\
\hline 1.0 & 1.0026 & -0.95 & No calc. & No calc. & No calc. & No calc. & No calc. \\
\hline 1.3 & 1.0917 & -1.04 & $0.72 w t \%{ }^{233} U$ & $0.78 w t \%{ }^{233} U$ & No calc. & $0.87 w t \%{ }^{233} U$ & $0.95 w t \%{ }^{233} U$ \\
\hline 1.5 & 1.1387 & -1.08 & $0.81 w t \%{ }^{233} \mathrm{U}$ & $0.89 w t \%{ }^{233} \mathrm{U}$ & No calc. & $0.99 w+\%{ }^{233} \mathrm{U}$ & $1.07 w \%{ }^{233} \mathrm{U}$ \\
\hline 5.0 & 1.4668 & -1.39 & $2.10 w t \%{ }^{233} \mathrm{U}$ & No calc. & $2.40 \mathrm{wt} \%{ }^{233} \mathrm{U}$ & No calc. & $2.76 w 1 \%{ }^{233} \mathrm{U}$ \\
\hline
\end{tabular}

If you have you have questions regarding this memo, please contact R. Q. Wright (574-5279). If you have further study needs please contact C. V. Parks (574-5280). I will be gone from Oak Ridge until March 30, 1998. 
Date: $\quad$ March 17,1998

To: $\quad$ C. M. Hopper

From: $\quad$ R. Q. Wright

Subject: XSDRN 238-group $k$-inf Calculations for Uranium-Water Systems

Calculated results for four U-235 cases with enrichments of $1.0,1.3,1.5$, and 5.0 wto are shown below. These U-235 cases correspond to optimum moderation for a uranium-water system (no SiO2 included).

URANIUM- 235

enrichment

$k-i n f$

1.0 wto $\quad 1.0026$

1.3 wto $\quad 1.0917$

1.5 wt: 1.1387

5.0 wt旁 $\quad 1.4668$

Two series of calculations were done for U-233 mixed with depleted uranium $(0.2$ wt: $U-235$, or $D U(0.2))$. The first series of cases is intended to be the U-233 equivalent of the 1.3 and 1.5 wt: U-235 cases. Cases. were run for SiO2 volume fractions of $0,0.3,0.5$, and 0.6 . In this first series of cases we determined the U-233 wt: corresponding to calculated $k$-infs in the range from 1.02 to 1.09 , which correspond to about 0.93 to 0.96 times the calculated U-235 values ( $1: 0917$ and 1.1387 ). Results for the first set of cases are shown in Figure 1 .

The second series of U-233/Si02/DU(0.2) cases corresponds to the 5 wto U-235 case. For this series we used SiO2 volume fractions of $0,0.4$, and 0.6 . For this second series we determined the U-233 wt: corresponding to calculated $k$-infs in the range 1.3 to 1.4 , corresponding to about 0.89 to 0.95 times the calculated U-235 value (1.4668). Results for these cases are shown in Figure 2. 


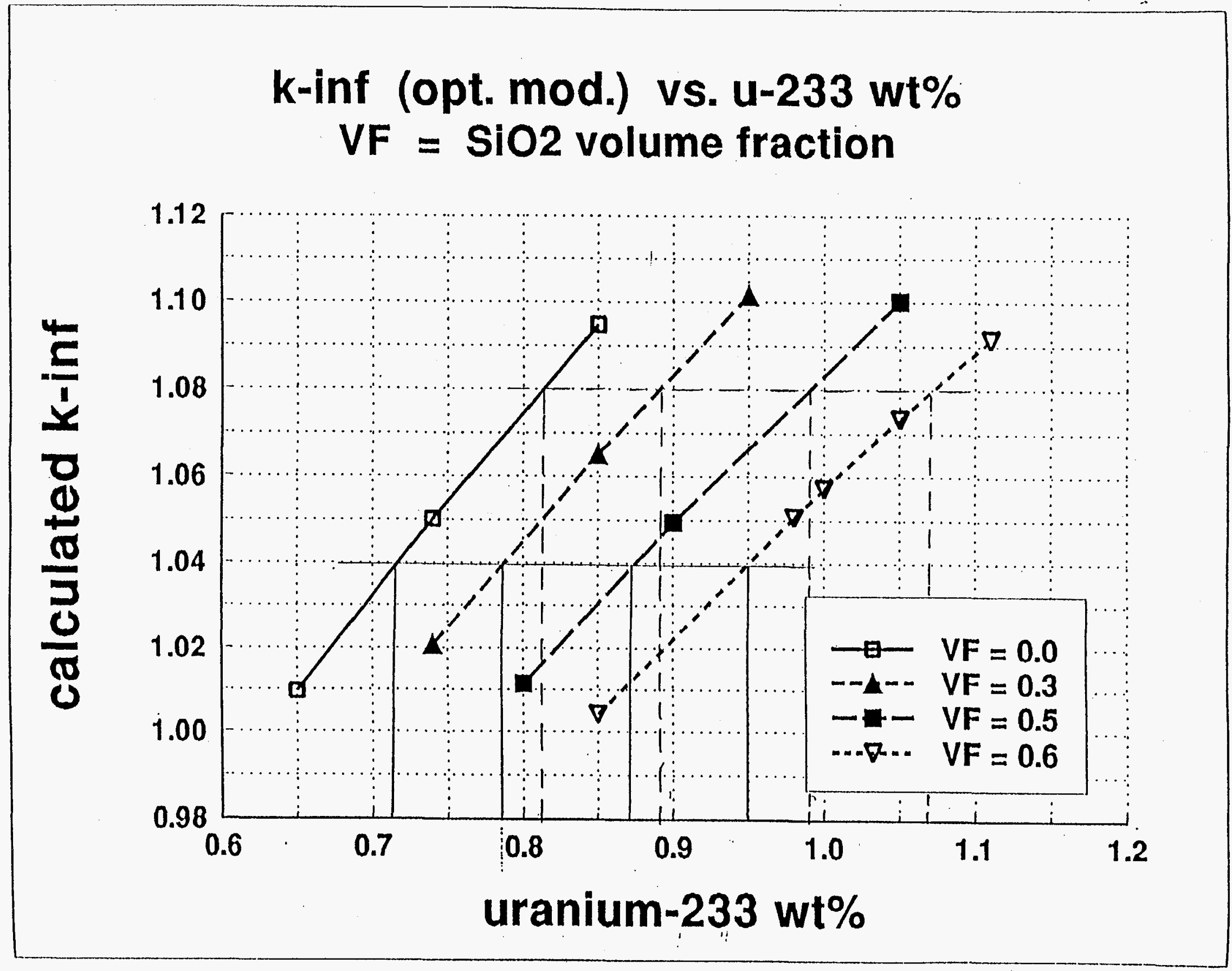




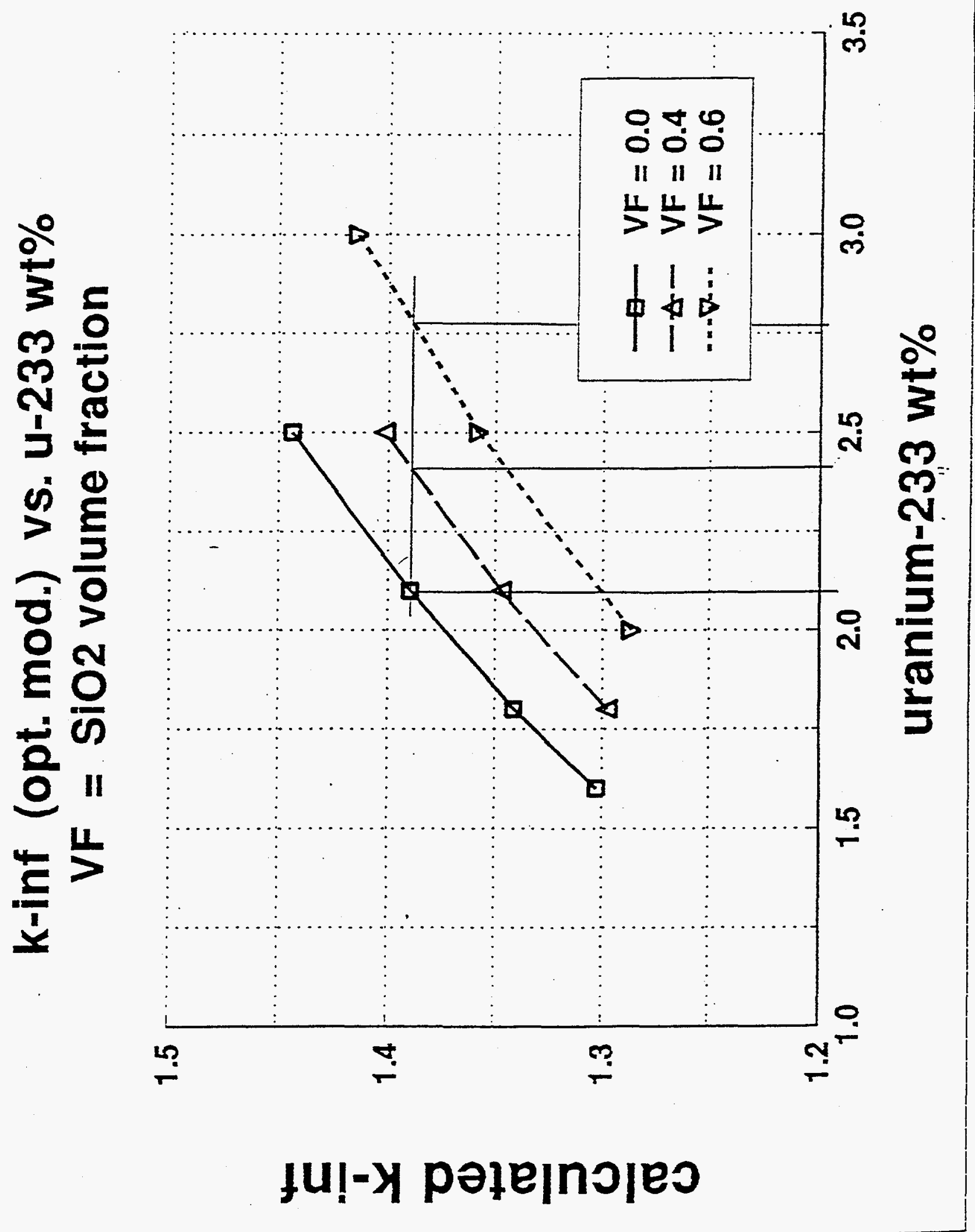




\section{INTERNAL DISTRIBUTION}

1. C. W. Alexander

2. J. J. Bedell

3. J. M. Begovich

4. P. J. Bereolos

5. B. B. Bevard

6. L. F. Blankner

7. H. E. Clark

8. E. D. Collins

9. S. O. Cox

10. A. G. Croff

11. W. D. Duerksen

12. K. R. Elam

13-17. C. W. Forsberg

18. E. H. Gift

19. L. L. Gilpin

20. N. M. Greene

21. S. R. Greene

22. M. J. Haire

23. C. M. Hopper

24. M. W. Kohring

25. A. M. Krichinsky

26. M. A. Kuliasha

27. A. J. Lucero

28. S. B. Ludwig

29. M. McBride

30. L. E. McNeese

31. G. E. Michaels
32. J. F. Mincey

33. H. J. Monroe

34. D. L. Moses

35. D. E. Mueller

36. R. D. Nipper

37. C. V. Parks

38. B. D. Patton

39. B. A. Powers

40. R. T. Primm, III

41. D. W. Ramey

42. D. A. Reed

43. D. E. Reichle

44. K. D. Rowley

45. J. E. Rushton

46. A. R. Sadlowe

47. B. W. Starnes

48-52. S. N. Storch

53. N. R. Sweat

54. J. R. Trabalka

55. D. Turner

56. O.F. Webb

57. K. A. Williams

58. R. Q. Wright

59. Central Research Library

60. Laboratory Records-RC

61. Document Reference Section

\section{EXTERNAL DISTRIBUTION}

62. Al Alm, U.S. Department of Energy, Assistant Secretary, Environmental Management, 1000 Independence Ave., S.W., Washington, D.C. 20585.

63. Joe Arango, U.S. Department of Energy, S-3.1, Rm. 6H-025, 1000 Independence Ave., S.W., Washington, D.C. 20585.

64. Mark C. Bronson, Lawrence Livermore National Laboratory, MS-394, P.O. Box 808, Livermore, California 94550.

65. Mathew Bunn, National Academy of Sciences, Founder's Bldg., 1055 Thomas Jefferson Street, N.W., Washington, D.C. 20007. 
66. H. R. Canter, U.S. Department of Energy, Acting Director, Office of Fissile Materials Disposition, 1000 Independence Ave., S.W., Washington, D.C. 20585.

67. Alice Caponiti, U.S. Department of Energy, Office of Fissile Materials Disposition, 1000 Independence Ave., S.W., Washington, D.C. 20585.

68. Nate Chipman, Idaho National Engineering and Environmental Laboratory, WCB, MS-3114, P.O. Box 1625, Idaho Falls, Idaho 83415-3114.

69. George Christian, Lockheed Martin Idaho Technologies Company, North Building, Suite 1404, 955 L'Enfant Plaza, S.W., Washington, D.C. 20024.

70. Norm Cole, Idaho National Engineering and Environmental Laboratory, P.O. Box 1625, Idaho Falls, Idaho 83415.

71. Ray Cooperstein, U.S. Department of Energy, Mail Stop DP-45, 19901 Germantown Rd., Germantown, Maryland 20874.

72. David Crawford, U.S. Department of Energy, 1000 Independence Ave., S.W., Washington, D.C. 20585.

73. Paul Cunningham, Los Alamos National Laboratory, MS-A102, P.O. Box 1663, Los Alamos, New Mexico 87545.

74. A. I. Cygelman, U.S. Department of Energy, Office of Fissile Materials Disposition, DOE/MD-3, Forrestal Bldg., Rm. 6G-050, 1000 Independence Ave., S.W., Washington, D.C. 20585.

75. Bill Danker, U.S. Department of Energy, DOE/MD-3, Forrestal Bldg., Rm. 6G-050, 1000 Independence Ave., S.W., Washington, D.C. 20585.

76. Tod Davis, Defense Nuclear Facility Safety Board, Suite 700, 625 Indiana Ave., N.W., Washington, D.C. 20004.

77. Abe Eiss, U.S. Nuclear Regulatory Commission, Washington, D.C. 20555.

78. Randy Erickson, Los Alamos National Laboratory, MS-F660, P.O. Box 1663, Los Alamos, New Mexico 87545.

79. John Evans, U.S. Department of Energy, 1000 Independence Ave., S.W., Washington, D.C. 20585.

80. Roland Felt, 780 DOE Place, Idaho Falls, Idaho 83415-1216.

81. Michael L. Gates, U.S. Department of Energy, Project Planning and Integration, Nuclear Materials Stewardship Project Office, Albuquerque Operations Office, P.O. Box 5400, Albuquerque, New Mexico 87185-5400. 
82. Mark W. Gibson, Babcock \& Wilcox Hanford, MSIN T5-55, P.O. Box 1200, Richland, Washington 99354.

83. Arnold Gnevara, U.S. Department of Energy, DOE/EM-66, 1000 Independence Ave., S.W., Washington, D.C. 20585.

84. Rose Gottemoller, U.S. Department of Energy, Office of Nonproliferation and National Security, 1000 Independence Ave., S.W., Washington, D.C. 20585.

85. Leonard W. Gray, Lawrence Livermore National Laboratory, MS-L394, P.O. Box 808, Livermore, California 94551.

86. M. Haas, U.S. Department of Energy, Rocky Flats Environmental Technology Site, P.O. Box 464, Golden, Colorado 80402.

87. James C. Hall, U.S. Department of Energy, Oak Ridge Operations Office, 20 Administration Rd., Oak Ridge, Tennessee 37831.

88. Reginald Hall, Advanced Integrated Management Service, Suite B3, 575 Oak Ridge Turnpike, Oak Ridge, Tennessee 37831.

89. Don Harlow, U.S. Department of Energy, 1000 Independence Ave., S.W., Washington, D.C. 20585.

90. Roger Henry, P. O. Box 1625, Idaho Falls, Idaho 83415-3805.

91. Frank Holmes, P.O. Box 1625, Idaho Falls, Idaho 83415.

92. Tim Hunt, U.S. Defense Nuclear Facilities Safety Board, Suite 700, 625 Indiana Ave., N.W., Washington, D.C. 20004.

93. Brent Ives, Lawrence Livermore National Laboratory, 7000 East Ave., Livermore, California 94550.

94. Bill Jensen, U.S. Department of Energy, MS 1101, 850 Energy Dr., Idaho Falls, Idaho 38401-1563.

95. Hoyt Johnson, U.S. Department of Energy, EM-66, Forrestal Bldg., 1000 Independence Ave., S.W., Washington, D.C. 20585.

96. Ed Jones, Lawrence Livermore National Laboratory, 7000 East Ave., L-634, Livermore, California 94550.

97. J. E. Jones, Jr., Haselwood Enterprises, Inc., Suite 300A, 1009 Commerce Park, Oak Ridge, Tennessee 37830.

98. William E. Kastenberg, University of California-Berkeley, Department of Nuclear Engineering, Berkeley, California 94720-1730. 
99. S. L. Krahm, Defense Nuclear Facilities Safety Board, Suite 700, 625 Indiana Ave., N.W., Washington, D.C. 20004.

100. Rodney Lehman, U.S. Department of Energy, DP-24, 19901 Germantown Rd., Germantown, Maryland 20874.

101-105. Leroy Lewis, Lockheed Martin Idaho Technologies Company, P.O. Box 1625, Idaho Falls, Idaho 83415.

106. Dennis Mangan, Sandia National Laboratory, P.O. Box 5800, Albuquerque, New Mexico 87185.

107. Herbert Massie, U.S. Defense Nuclear Facilities Safety Board, Suite 700, 625 Indiana Ave., N.W., Washington, D.C. 20004.

108. Mal McKibben, Westinghouse Savannah River Company, Savannah River Site, Bldg. 773-41A, Rm. 123, Aiken, South Carolina 29808.

109. T. McLaughlin, Los Alamos National Laboratory, ESH-6, P.O. Box 1663, Los Alamos, New Mexico 87545.

110. Don McWhorter, Westinghouse Savannah River Company, Savannah River Site, Bldg. 704-F, Aiken, South Carolina 29808.

111. Barry Mendelsohn, U.S. Nuclear Regulatory Commission, Washington, D.C. 20555.

112. Lawrence E. Miller, U.S. Department of Energy, DOE/NE-40, 19901 Germantown Rd., Germantown, Maryland 20874.

113. M. Miller, Massachusetts Institute of Technology, Security Studies Program, E38-603, 292 Main Street, Cambridge, Massachusetts 02139.

114. Ed Moore, Westinghouse Savannah River Company, Savannah River Site, Bldg. 773-41A, Rm. 125, P.O. Box 616, Aiken, South Carolina 29808.

115. Bruce Moran, U.S. Nuclear Regulatory Commission, MS-T-8-A33, Washington, D.C. 20555.

116. Jim Nail, Lockheed Martin Idaho Technologies Company, P.O. Box 1625, Idaho Falls, Idaho 83415.

117. Dave Neiswander, Advanced Integrated Management Services, Inc., Suite B-3, 575 Oak Ridge Turnpike, Oak Ridge, Tennessee 37830.

118. Jon Nielsen, Los Alamos National Laboratory, P.O. Box 1663, Los Alamos, New Mexico 87545.

119. David Nulton, U.S. Department of Energy, Office of Fissile Materials Disposition, 1000 Independence Ave., S.W., Washington, D.C. 20585. 
120. Dave Pepson, U.S. Department of Energy, 1000 Independence Ave., S.W., Washington, D.C. 20585.

121. Per F. Peterson, University of California-Berkeley, Department of Nuclear Engineering, Berkeley, California 94720-1730.

122. K. L. Pilcher, Haselwood Enterprise, Inc., Suite 300A, 1009 Commerce Park, Oak Ridge, Tennessee 37830.

123. K. K. S. Pillay, Los Alamos National Laboratory, P.O. Box 1663, Los Alamos, New Mexico 87545.

124. Gary Polansky, Sandia National Laboratory, MS-0727, P.O. Box 5800, Albuquerque, New Mexico 87185.

125. Victor Reis, U.S. Department of Energy, Assistant Secretary, Defense Programs, 1000 Independence Ave, S.W., Washington, D.C. 20585.

126. D. R. Rhoades, U.S. Department of Energy, DP24, 1000 Independence Ave., Washington, D.C. 20585-0002.

127. John Richter, 5917 Royal Oak St., N.E., Albuquerque, New Mexico 87111.

128. Gary D. Roberson, U.S. Department of Energy, NMSPO, P.O. Box 5400, Albuquerque, New Mexico 87185-5400.

129. Greg Rudy, U.S. Department of Energy, Bldg. 703-A/E245N, P.O. Box A, Aiken, South Carolina 29802.

130. S. S. Sareen, TRW, Suite 800, 2650 Park Tower Dr., Vienna, Virginia 22180.

131. Adam Schienman, U.S. Department of Energy, DOE/NN-40, 1000 Independence Ave., S.W., Washington, D.C. 20585.

132. Linda Seward, Idaho National Engineering and Environmental Laboratory, P.O. Box 1625, Idaho Falls, Idaho 83415.

133. Michelle Smith, U.S. Department of Energy, DOE/NN-40, 1000 Independence Ave., S.W., Washington, D.C. 20585.

134. Robert Stallman, U.S. Department of Energy, 850 Energy Dr., Idaho Falls, Idaho 38401.

135. Warren Stern, Arms Control and Disarmament Agency, Rm. 4678, 32021 st Street, N.W., Washington, D.C. 20451.

136. Elmer Stover, U.S. Department of Energy, DOE/NN-30, Rm. GA301, 1000 Independence Ave., S.W., Washington, D.C. 20585. 
137. G. H. Thompson, Rocky Flats Environmental Technology Center, Kaiser-Hill Nuclear Operations, P.O. Box 464, Golden, Colorado 80402-0464.

138. John Thompson, U.S. Department of Energy, Office of Fissile Materials Disposition (DOE/MD), 1000 Independence Ave., S.W., Washington, D.C. 20585.

139. Dean Tousley, U.S. Department of Energy, MD-4, 1000 Independence Ave. S.W., Washington, D.C. 20585.

140. John Tseng, U.S. Department of Energy, DOE/EM-66, Forrestal Bldg., Rm. GA-242, 1000 Independence Ave., S.W., Washington, D.C. 20585.

141. Harry Vantine, Lawrence Livermore National Laboratory, P.O. Box 808, Livermore, California 94550.

142. Don Vieth, 1154 Cheltenham Place, Maineville, Ohio 45039.

143. Gary Wall, Los Alamos National Laboratory, MS-F669, P.O. Box 1663, Los Alamos, New Mexico 87545.

144. Mike Webb, Los Alamos National Laboratory, MS-F669, P.O. Box 1663, Los Alamos, New Mexico 87545.

145. Bob Whitesel, U.S. Department of Energy, DOE/NN-44, 1000 Independence Ave., S.W., Washington, D.C. 20585-0440.

146. John Wilcynski, Manager, U.S. Department of Energy, Idaho Operations Office, MS-1203, 850 Energy Drive, Idaho Falls, Idaho 83401-1563.

147. Jeff Williams, Idaho National Engineering and Environmental Laboratory, P.O. Box 1625, Idaho Falls, Idaho 83415.

148. Wendell L. Williams, U.S. Department of Energy, MD-3, Forrestal Bldg., 6G-081, 1000 Independence Ave., S.W., Washington, D.C. 20585.

149. C. R. Wolfe, Westinghouse Savannah River Company, Savannah River Site, Bldg. 773-A, Aiken, South Carolina 29808.

150. Jon Wolfstahal, U.S. Department of Energy, DOE/NN-40, 1000 Independence Ave., S.W., Washington, D.C. 20585.

151. Loong Yung, Advanced Integrated Management Service, Suite B3, 575 Oak Ridge Turnpike, Oak Ridge, Tennessee 37831.

152. Neil R. Zack, Los Alamos National Laboratory, MS-E541, P.O. Box 1663, Los Alamos, New Mexico 87545.

153. Office of Assistant Manager of Energy Research and Development, P.O. Box 2008, DOE-ORO, Oak Ridge, Tennessee 37831-6269. 
154-155. Office of Scientific and Technical Information, P.O. Box 62, Oak Ridge, Tennessee 37831. 